Florida International University FIU Digital Commons

$11-9-2016$

\title{
Informal Urban Displacement in Rio de Janeiro: Ecolimits and Disaster Biopolitics in the Favela Santa Marta
}

Charles L. Heck

Florida International University, check@fiu.edu

DOI: 10.25148 /etd.FIDC001237

Follow this and additional works at: https://digitalcommons.fiu.edu/etd

Part of the Human Geography Commons, and the International and Area Studies Commons

\section{Recommended Citation}

Heck, Charles L., "Informal Urban Displacement in Rio de Janeiro: Ecolimits and Disaster Biopolitics in the Favela Santa Marta" (2016). FIU Electronic Theses and Dissertations. 2987.

https://digitalcommons.fiu.edu/etd/2987 


\title{
FLORIDA INTERNATIONAL UNIVERSITY
}

\author{
Miami, Florida
}

INFORMAL URBAN DISPLACEMENT IN RIO DE JANEIRO:

ECOLIMITS AND DISASTER BIOPOLITICS IN THE FAVELA SANTA MARTA

\author{
A dissertation submitted in partial fulfillment of \\ the requirements for the degree of \\ DOCTOR OF PHILOSOPHY \\ in
}

GLOBAL AND SOCIOCULTURAL STUDIES

by

Charles L. Heck 
To: Dean John F. Stack, Jr.

Steven J. Green School of International and Public Affairs

This dissertation written by Charles L. Heck, and entitled Informal Urban Displacement in Rio De Janeiro: Ecolimits and Disaster Biopolitics in Favela Santa Marta, having been approved in respect to style and intellectual content, is referred to you for judgment.

We have read this dissertation and recommend that it be approved.

$\begin{array}{r}\hline \text { Harry Gould } \\ \hline \text { Juliet Erazo } \\ \hline \text { Benjamin Smith } \\ \hline \text { Roderick Neumann, Major Professor }\end{array}$

Date of Defense: November 9, 2016

The dissertation of Charles L. Heck is approved.

Dean John F. Stack, Jr. Steven J. Green School of International and Public Affairs

Andrés G. Gil Vice President for Research and Economic Development and Dean of the University Graduate School

Florida International University, 2016 
(C) Copyright 2016 by Charles L. Heck

All rights reserved. 


\section{ACKNOWLEDGMENTS}

This dissertation was made possible by the generous financial support I received during my coursework and research. For language training, I received the Department of Education's Foreign Language and Area Studies fellowship for Brazilian Portuguese through FIU's Latin American and Caribbean Center. This fellowship began my interest in Rio de Janeiro as a study site. My preliminary field research was funded through awards from the Anita and Morris Broad Research Fellowship and the Tinker Foundation

grant from the Latin America and Caribbean Center at FIU. My dissertation field research was funded by FIU's Dissertation Evidence Acquisition award. Many people helped me along the way, but I would like to especially thank Dr. Bryan McCann at Georgetown University for his help in putting me in contact with Dr. Sonia Fleury at the Fundação Getúlio Vargas, who became my host sponsor in Rio de Janeiro. Dr. Fleury and her research team at FGV were an enormous asset for my field research and without them this dissertation would have been limited. At FIU, Dr. Kevin Grove's comments on a draft chapter changed the course of later chapters for the better. Finally, I would like to thank my committee members for all of their feedback and help. 


\begin{abstract}
OF THE DISSERTATION
INFORMAL URBAN DISPLACEMENT IN RIO DE JANEIRO:

ECOLIMITS AND DISASTER BIOPOLITICS IN THE FAVELA SANTA MARTA
\end{abstract}

by

Charles L. Heck

Florida International University, 2016

Miami, Florida

Professor Roderick Neumann, Major Professor

This dissertation examines the effect of environmental discourse and disaster risk reduction mapping in the favela Santa Marta, an urban informal settlement in the municipality of Rio de Janeiro, Brazil. With the world's largest urban forest within the metro area, Rio de Janeiro is unusual for a metropolis of more than ten million people in the rapidly urbanizing country of Brazil. The government of Rio de Janeiro has attempted to control favela settlements since the early $20^{\text {th }}$ century, but beginning in the 1990 s the prefecture began delimiting favela settlements with environmentally protected areas called ecolimits. According to the state's calculations, in the 2000s favelas began to rapidly expand into urban forest, which is protected by the ecolimits and national parks in Rio de Janeiro. The state then labeled Santa Marta the model favela after infrastructure improvements there and the installation of the first Pacification Police Unit, a new form of community policing begun in 2008 for favelas. In 2009, the state built a wall around Santa Marta, justified by concerns about expansion into the adjacent urban forest.

The focus of my study is the particular ways that the government has framed its resettlement efforts in Santa Marta and how favela residents responded. I employ the 
concept of biopolitics assemblage to critically investigate the state's and international institutions' discursive and material practices of disaster risk management in Santa Marta. I collected data using a mixed methods approach during 15 months of fieldwork. Through archival research, I document the history of favela control tactics and trace the roots of disaster risk management in Rio de Janeiro to a World Bank financed disaster response project initiated in 1988. Using ethnographic methods, I documented residents' responses to and understandings of the government's resettlement project for Santa Marta. My results indicate that the state has discursively shifted the problem of favelas from a social question to an environmental one, while residents continue to frame favela conditions as a social justice issue and challenge the state's assessment of environmental risk. 


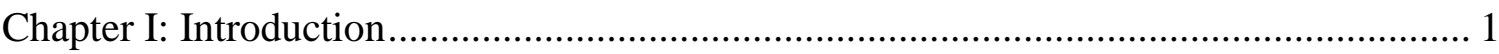

Research significance and theoretical overview …….............................................. 2

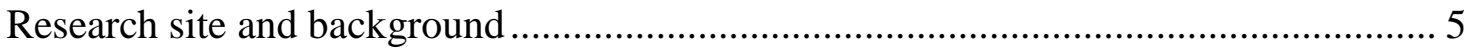

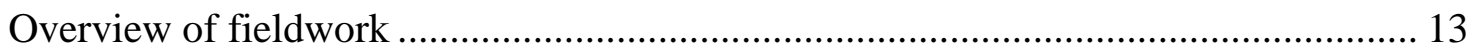

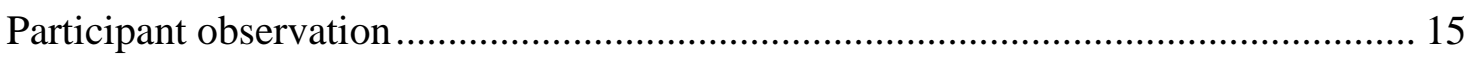

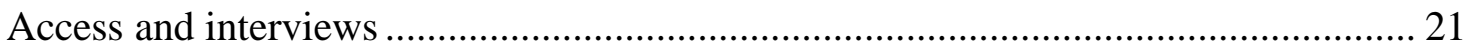

Participatory action research techniques ................................................................. 22

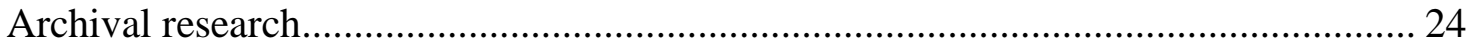

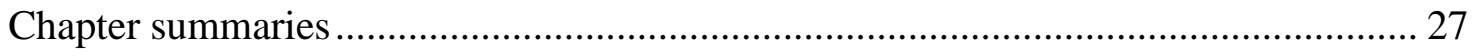

Chapter II: Biopolitics and the Assemblage Framework ……….................................... 31

Foucault's analytics of power and green governmentality............................................ 34

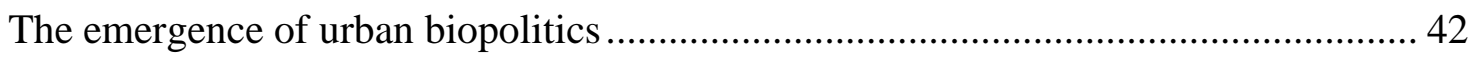

Disaster biopolitics: risk mapping, climate, geology, displacement ............................. 47

Analytics of governmentality and assemblages ...................................................... 52

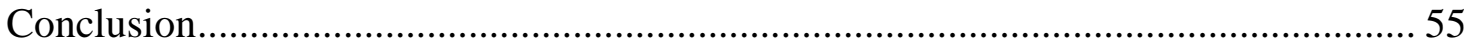

Chapter III: A History of Favela Control Discourses and Interventions ........................... 57

Favela control discourses: Health, morality, and anti-communism (1920-1962) ......... 58

Favela eradication: Urbanization as favela displacement (1962-1973) ........................ 62

Santa Marta: From the threat of removal to threat to the environment ........................... 68

Urbanization and disaster risk mapping focus on favelas ............................................ 75

Favela Urbanization: Ecolimits and territorial control............................................... 85

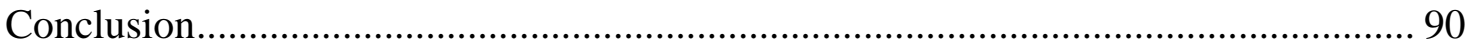

Chapter IV: Ecolimits, Resilience Biopolitics, and Resettlement in Santa Marta............ 92

Resilience biopolitics and the Morar Seguro resettlement plan ...................................... 99 
The return of urbanization and resettlement to Santa Marta .................................... 111

Community organization before the return of urbanization.................................... 123

Resident responses to the urbanization plan at the general assembly ...................... 131

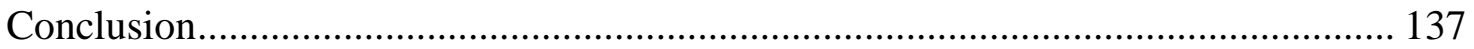

Chapter V: Discourses of Risk and Urbanization in Santa Marta .............................. 138

Naturalizing and mapping risk in Santa Marta: The GeoRio meeting...................... 142

Three episodes of resident responses to risk discourse in Santa Marta .................... 149

Episode One: The response to the GeoRio presentation ........................................ 149

Episode Two: The contralaudo presentation in Santa Marta .................................... 156

Episode Three: The Hike Against Removals ......................................................... 158

Counterdiscourses in the Disaster Risk Reduction (DRR) assemblage ..................... 160

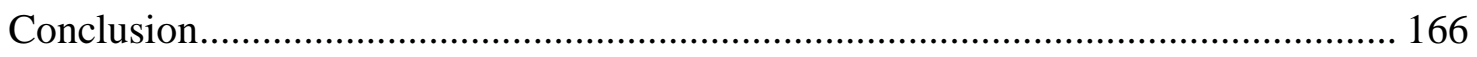

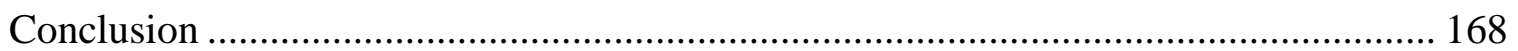

References................................................................. 181

Vita....................................................................200 


\section{LIST OF FIGURES}

$\begin{array}{lll}\text { FIGURE PAGE } & \text { PAR }\end{array}$

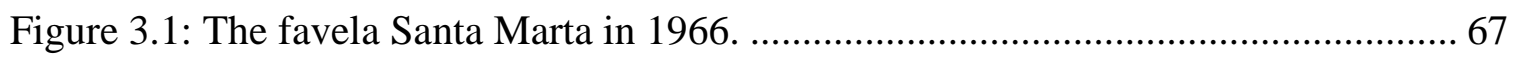

Figure 3.2: Santa Marta and Botafogo circa 1975 ................................................... 71

Figure 3.3: Comparison of Aerial Photos of Santa Marta from 1975 and 1985............. 73

Figure 3.4: 1988 Landslide Susceptibility Map of the Municipality of Rio de Janeiro.... 77

Figure 3.5: Residential settlements on the Tijuca Massif above 100 meters................... 86

Figure 4.1: Area of Special Social Interest map of Santa Marta ................................. 98

Figure 4.2: Flyer for the "Roots of the Santa: SOS from the Peak" event. ................... 109

Figure 4.3: Urbanization plan showing the reforestation of the Peak........................... 111

Figure 4.4: 2003 Santa Marta resident designed urbanization committee plan............. 123

Figure 4.5: Fernanda Salles 2004 post state contract plan......................................... 125

Figure 5.1: Map of homes scheduled for resettlement on the Peak............................ 141

Figure 5.2: 1988 Landslide at Santa Marta............................................................ 145

Figure 5.3: Map of susceptibility of landslides of Santa Marta and surrounding area... 148 


\section{LIST OF ABBREVIATIONS AND ACRONYMS}

AEIS

APA

BID

CHISAM Coordenadoria da Habitação de Interesse Social da Área Metropolitana do Rio de Janeiro ( Coordination of Social Interest Housing of the Greater Rio Metropolitan Area)

CODESCO Companhia de Desenvolvimento Comunitário (Community Development Company)

COHAB Companhia de Habitação (Housing Company)

EMOP Empresa de Obras Públicas do Estado do Rio de Janeiro (Public Works Company of the State of Rio de Janeiro)

FAFERJ Federação das Associações de Moradores de Favelas do Estado do Rio de Janeiro (Federation of Favela Associations of the state of Rio de Janeiro)

FAFEG Federação de Favelas do Estado da Guanabara (Federation of the Favelas of Guanabara State)

FAMERJ Federação das Associações de Moradores do Estado do Rio de Janeiro (Federation of the Residents' Association of the State of Rio de Janeiro)

GEO-RIO Fundação Instituto de Geotécnica do Rio de Janeiro (Geotechnical Institute Foundation of Rio de Janeiro)

FIRJAN Federação das Indústrias do Rio de Janeiro (Federation of Industries of Rio de Janeiro)

IAB-RJ Instituto de Arquitetos do Brasil do Rio de Janeiro (Brazilian Institute of Architects in Rio de Janeiro)

IBDF Instituto Brasileiro de Desenvolvimento Florestal (Brazilian Forest Development Institute)

IBGE Instituto Brasileiro de Geografia e Estatística (Brazil Institute for Geography and Statistics) 
IETS Instituto de Estudos do Trabalho e Sociedade (Institute for Labor and Society Studies)

IPP Instituto Municipal de Urbanismo Pereira Passos (Pereira Passos Institute)

MCMV Minha Casa Minha Vida (My Home My Life)

PAC Programa de Aceleração do Crescimento (Growth Acceleration Program)

POUSO Posto de Orientação Urbanística e Social (Social and Urban Orientation Office)

SERFHA Serviço Especial de Recuperação de Favelas e Habitações AntiHigiênicas (Special Service of the Recovery of Favelas and Anti-hygienic Housing)

SMAC Secretaria Municipal de Meio Ambiente (Municipal Secretariat of the Environment)

SMH Secretaria Municipal de Habitação

TNP Parque Nacional de Tijuca (Tijuca National Park)

UPP Unidade de Polícia Pacificadora (Pacification Police Units) 


\section{Chapter I: Introduction}

In recent years, the state of Rio de Janeiro (Rio) began implementing new forms of control for its favelas (informal settlements, popularly referred to as slums or shantytowns). The state initiated the control programs in the favela named Santa Marta, which it labeled "the model favela" after a new form of community policing called the Unidade de Policia Pacificadora or UPP (Pacification Police Unit) was installed there in November of 2008. Then in May 2009, the Rio municipal authorities released a study indicating that the city's favelas were expanding past the ecolimites (ecolimits) established between favelas and environmentally protected areas, and subsequently began the construction of a two meter wall the state of Rio called an ecobarreira (ecobarrier) between Santa Marta and the protected forest area to the west. The state then presented Santa Marta as a model for managing favelas throughout the region, despite strong evidence from municipal analyses that Santa Marta had decreased in size over previous decades. In 2010, a new form of favela expansion control was introduced that was designed to establish the limits of urban settlement throughout Rio. Santa Marta became a conspicuous site of the new state intervention to reduce disaster risk in the wider Rio metropolitan area called Morar Seguro (Live Safely).

In this dissertation I investigate how the concepts ecolimits and disaster risk discursively created the conditions for the displacement of favela residents, while simultaneously producing new protected areas for reforestation as a mitigation strategy. Using ethnographic and archival methods, I trace the state's efforts to control the space of the favela and document the responses of residents to resettlement. I assemble an analytic 
to study this urban land use conflict using the concepts of governmentality and biopolitics, thereby extending the new notion of "green governmentality" to urban informal settlements.

\section{Research significance and theoretical overview}

Favelas, as particular types of informal settlements, are a form of what Ananya Roy calls informal urbanity, in recognition that informal settlements are part of the city and the process of urbanization (Roy and AlSayyad 2004). Perlman writes that it is difficult to compose a definition of favelas that encapsulates all the variations for which the term is used (Perlman 2010, 29-30). The Brazilian government distinguishes favelas, which it calls "subnormal agglomerations", from other types of settlements based on the absence of centralized urban planning, legal title to land, and limited or absent access to state services and formalized utilities (IBGE 2010). The scholarly literature on informal settlements is largely focused on either violence or the socioeconomic status of slums, ignoring the land use conflicts between informal settlements and protected areas that were increasingly common in places like India, Brazil, and Mexico. This dissertation examines the ways that government attempts to control the process of urban expansion and the contradictions that are being produced. In this regard, the chapters from Planet of Slums on slum segregation, displacement, and risk of disasters provided a guide for my empirical exploration into the rapid urbanization of Brazil and the slums of Latin America (Davis 2006).

While much of the informal settlement literature focuses on informal settlement growth as the leading edge of global urbanization and the problems that come with an 
increasingly urban global population (Davis 2006; Evans 2002; Koonings and Kruijt 2007; Koonings and Kruijt 2009), this dissertation focuses on informal settlement management, specifically the management of favelas in Rio de Janeiro. Recent ethnographies of favelas in Brazil have tended to focus on the lived experience and effects of drug violence (Scheper-Hughes 1992; Goldstein 2003; Garmany 2011; Garmany 2014; Penglase 2014) or on crime and social segregation (Teresa Caldeira 2000). A few scholars have examined so called environmental conflicts with informal settlements in other parts of the world (Evans 2002; Davis 2006; Ghertner 2011), but very little research has been carried out using in depth field research specifically on the management of favelas and the emergence of protected areas.

Theoretically, I set out to do four things. First, I wanted to examine the greening of favela control using the green governmentality literature (S. Rutherford 2007; Michael Goldman 2001; Brand 2007; Darier 1999) — a variation of governmentality studies based largely on the writings of Michel Foucault — which while offering a critical analysis of sustainable development and urban sustainability, provided little empirical work in support. I also set out to address the critique of governmentality studies on the grounds that governmentality tended to overemphasize the ability of governmental techniques to produce docile subjects. Second, I sought to investigate how particular green discourses and assemblages emerged in Brazil from a post-structural standpoint. Specifically, when and how did the political technology "area of risk" emerge and how should we understand it in relation to efforts to control favelas expansion into Rio's urban rainforests like the ecolimit and ecobarrier? Furthmore, I wanted to explore the role that global forces like the World Bank and United Nations played in producing green 
assemblages in Brazil. Third, I saw the need for an analytics of Foucaultian biopolitics that emphasized political practice as its empirics. Many approaches to biopolitics use a discursive approach where practice - in the sense of how biopolitics is embodied in a particular place- has been muted in favor of describing how the state calculates and aggregates a collection of things into an abstract concept that can be regulated by the state. Fourthly, I wanted to pay attention to the responses to favela displacement framed by discourses of greened favela control.

Initially, I planned to use a version of green governmentality that examined how self-surveilling subjects were formed from environmental discourse and were produced by the conduct of conduct in a decentralized manner (Agrawal 2005; Brand 2007; Michael Goldman 2001). As events unfolded at my research site, I focused on resident responses to the disaster risk reduction program in Santa Marta. I therefore shifted toward an analytic of Foucaultian biopolitics rooted in the work in geography (S. Rutherford and Rutherford 2013; Legg 2005; Legg 2008). Recently, scholars have worked on disaster risk reduction (DRR) discourse using an analytics of biopolitics (Grove 2013a; Grove 2014a; Zeiderman 2012; Zeiderman 2013), adding to the body of geography scholars using biopolitics for urban research (Bakker 2013; Legg 2006; Legg 2008; Gandy 2006; Braun 2014; Outtes 2003). This dissertation makes a contribution at the intersection of the biopolitics scholarship and the work in political ecology on land use conflicts and place based struggles (Neumann 2005; Peet, Robbins, and Watts 2011; Watts and Peet 2004; Wolford 2010). 


\section{Research site and background}

In the 2000s Brazil was a driving force among the rapidly growing BRIC states, with new petroleum reserves discovered, a commodities boom, and a leftwing president that appeared to be transforming Brazil from one of the world's most unequal economies into a new global force. Brazilian telenovelas and music were playing throughout Latin America, and Brazil began to increase its influence in international economic organizations like the Mercosur and the G20. Brazil had the largest population in Latin America, was urbanizing rapidly, and was home to two of the four megacities with populations greater than ten million people in Latin America-São Paulo and Rio de Janeiro. However, this urban growth, which was largely in the form of favelas, was producing problems that resulted in negative attention at the same time that Brazil's image was going global. In the mid-2000s, drug trafficking violence called international attention to Rio de Janeiro's favelas after turf wars spilled out into the tourist districts. After coverage in the international media, the episodes of violence hurt the tourist industry that Brazil had been developing for decades, especially in Rio. Rio's favelas were harming the image of Brazil that Lula was trying to promote to international investors as an up and coming BRIC state. Brazil had already attempted to resolve the “favela problem" several times in its history (Fischer 2008; Perlman 2010).

The government of Rio de Janeiro had attempted to eliminate, displace or reduce the number of favelas several times since the early 1900s (Perlman 1976; Burgos 1998; Valladares 2005). The programs for favela removals in the 1960s and 1970s failed to reduce the number of favelas, but had the effect that they displaced favelas from highly valued property zones in the Central and Southern zones of Rio de Janeiro to other distant 
favelas and government housing projects (Perlman 2010). In the 2000s, the government of Rio became alarmed at studies showing that favelas were once again growing rapidly, a concern that was added to the already hard to control drug trafficking problem concentrated in Rio's favelas since the 1980s. In 2004 after an episode of violence stopped traffic for days in an upscale Rio suburb, the government of Rio announced its intent to build walls around several of Rio's favelas to contain drug violence. Rio's activists heavily criticized the proposal to wall off the favelas in the media as a form of "social apartheid" and the government shelved the proposal. In 2008, Rio de Janeiro was selected as the site of the 2016 Olympics and Rio's newly elected mayor Eduardo Paes declared that he would use the 2014 World Cup in Rio and the Olympics as the justification to implement a bold new urban renewal plan. The first step of this plan was a new community policing program for favelas called the Unidade de Policia Pacificadora or UPP (Pacification Police Unit). Managed by Rio's military police, who were in charge of public safety in the Rio metropolitan area, the new policing program was designed to reduce drug trafficking violence in Rio's favelas by taking control from drug traffickers and introducing a less corrupt and more social police force. With favelas under control, the next step was to implement a series of urban public policy interventions in favelas that had previously been limited by drug trafficker control. The rapid construction of the ecobarrier wall immediately followed the installation of the UPP in Santa Marta.

While the UPP program was widely lauded at the time as a long overdue state attempt to control violence related to drug trafficking, the ecobarrier was criticized as a form of greened apartheid by observers such as Amnesty International and the social critic and writer José Saramongo. Further critiques were launched by activists in Rio after 
satellite photos revealed that Santa Marta was not expanding into the forest, contrary to the justification given by the state for constructing the ecobarrier, but had diminished in spatial extent since the 1990s. After these two programs were initiated in Santa Marta, the government of Rio began using Santa Marta as a "vitrine" (showcase or display) for both the willingness of the state to address the "favela problem" and for government programs that would later be expanded to other favelas of Rio. Rio's government began promoting the programs initiated in Santa Marta by calling it the "model favela". This meant that the government used Santa Marta as a testing ground for programs for larger favelas in different urban geographies throughout the Rio metro area, a perspective that did not go unnoticed by Santa Marta residents. From a Human Geography perspective, I viewed these contradictory framings of Santa Marta as new forms of green governmentality for the control of informal settlements that aligned with the critiques of neo-Malthusianism and sustainability found in the political ecology literature (Watts and Peet 2004; Peet, Robbins, and Watts 2011; Neumann 2005).

The ecobarrier controversy had historical roots in the emergence of a political technology called an ecolimite, or ecolimit. The ecolimit was created as part of the urban upgrading program Favela-Bairro begun in the 1990s and delimited favela borders from legally protected forest areas, called an Area de Proteção Ambiental (Environmental Protection Area). Those protected areas could be expanded to "areas of risk", which were areas mapped by government of Rio under a classification of high risk for disaster events like floods and landslides. Rio is a city of forested mountains and valleys in a coastal zone, so much of the surrounding geography of Rio's urban space is mapped as either an Area de Proteção Ambiental or an area of risk. During the Favela-Bairro program, favelas 
were selected for their pre-existing advantages for upgrading with urban infrastructure, meaning that they selected favelas with minimal disaster risk assessments and attempted to prevent favela expansion with the ecolimits and POUSOs, the new urban zoning monitors for favelas. In the mid-2000s, studies were released that convinced the urban policy apparatus of Rio that the ecolimits had failed and that the favelas were rapidly expanding past the ecolimits. These critiques of state policy set the stage for the political pressure to implement new programs for favela control in Rio, especially after Rio was selected as the site for the 2016 Olympics in 2008. The UPP program received the most press coverage as an ongoing and expanding program, while the ecobarrier program was discontinued in 2010 after global criticism.

In 2010 and 2011, Rio was beset with torrential rainfalls followed by landslides in both favelas and the suburbs surrounding the Rio metro area with full access to state services. These events accelerated and expanded programs already in progress to reduce disaster risk in Rio's favelas, in particular the 2010 disaster risk resettlement program called Morar Seguro (Live Safely) by the government of Rio. In 2010, the prefecture of Rio announced that it would remove 119 favelas in risk areas or public areas before 2012 in order to reduce the favela population of Rio by 3.5 percent (Faulhaber and Azevedo 2016). After the rains of 2010, the prefecture of Rio rapidly carried out disaster risk mapping of the entire metro area and demolished smaller favelas mapped in high risk areas or in key locations for the urban renovation project, without the compensation or resettlement required under Brazilian law. This first wave of favela displacements leading up to the 2016 Olympics was criticized by Amnesty International and the United Nations Human Rights division. Tens of thousands of favela residents were displaced from the 
path of the urban renovations and areas mapped as high risk from 2010 to 2012. The state and prefecture of Rio constructed new transportation systems across the Rio metro area and a renovation of the port area in the center of Rio. According to the prefecture's own records, out of a total of 37,000 people displaced, 45 percent were displaced using the area of risk justification (Faulhaber and Azevedo 2016). A majority of the latter were favela residents whom were resettled to government housing projects in the distant west zone of Rio. While Santa Marta was not damaged by the 2010 and 2011 rains, after the emergency response was underway in other parts of Rio, the state turned its attention to Santa Marta and more specifically the portion of the favela on the top of the hill known locally as "the Peak."

According to its eldest residents, the first shacks that would become Santa Marta were built on the hill named Dona Marta in the late 1930s, making Santa Marta one of the oldest favelas in Rio, although the prefecture of Rio de Janeiro first recorded an accumulation of migrant workers living near Botafogo in 1942, (Silva 2011). These workers migrated from the state of Minas Gerais and northeastern Brazil. Many of them helped build the nearby Catholic school and the Catholic Church organized residents into a community that was recognized by the prefecture when the residents' association was established in 1965 (Silva 2003). The entrance to the favela opens directly into the old working class Botafogo neighborhood of Rio, which connects the neighborhoods of Lagoa and Copacabana with the city center. Santa Marta's autoconstrução (selfconstructed homes) are clustered into a strip that ascends up one of Rio's large hills. The western side of the favela is bounded by a drainage system for runoff from the hill above and the eastern side of the favela is bounded by the mechanism used to transport goods 
and people to the higher reaches of Santa Marta called a funicular tram, henceforth the tram. As one moves away from Botafogo and up the hill, apartment complexes give way to well built, but loosely organized multistory buildings. Behind these buildings, at an angle that requires craning one's neck upward, other buildings made of wood and brick can be seen at the base of a large rock face forming the uppermost border of the favela on the northeast.

The 2010 Brazilian census estimated Santa Marta's population as 3900, while the private research institution IETS estimated the population as 4700 that same year in a survey of heads of households for insurance market research (IETS 2010). The residents' association and Itamar Silva of Santa Marta estimate that there are more than 7000 people living in Santa Marta, based on other independent surveys of favela residents. I present these different estimates to show the uncertainty about the population of favelas, especially larger favelas. Perlman discusses some of the difficulties of carrying out a census in a Brazilian favela, including the absence of grid organization, there are multiple families in the same building, people may not want to respond for a variety of reasons, and some are migrants who rent and are rarely home (Perlman 2010). And these difficulties are only increased in favelas run by drug traffickers. Although Santa Marta was controlled by the UPP during my field research and the international media had reported that the UPP was displacing drug trafficking from favelas, it became apparent early on that clandestine drug traffickers had remained in Santa Marta. According to that IETS survey, there were 1390 households in Santa Marta, seventy-nine percent of Santa Marta's head of households owned their homes and sixty percent of heads of households were black or mixed race. A majority of Santa Marta residents made the minimum wage 
or less, which in 2010 was 500 Brazilian reals per month. ${ }^{1}$ According to the Instituto Pereira Passos (IPP), the municipal government's urban policy institute of Rio de Janeiro, the lower portion of Santa Marta is classified as an urbanized settlement that has access to municipal services and utilities, while the upper portion is currently being urbanized by the state of Rio (IPP 2014). The 2010 census estimated that twenty-two percent of Rio de Janeiro's population lived in favelas, the largest total favela population of any city in Brazil. According to the 2010 census, Rio's favelas had grown by twenty-eight percent from the 2000 census, while the rest of the city's population had grown by less than four percent. In the southern zone of Rio where the tourist areas and Botafogo are located, favelas grew by fifteen percent, while the population of Santa Marta grew only four percent from 2000 to 2010. According to estimates by the state of Rio, there are one hundred fifty homes mapped in the high risk zone on the Peak, where I focused my research. I estimate using IETS's and the state of Rio's figures that approximately five hundred people were targeted by the resettlement program, which is close to ten percent of Santa Marta's population.

During my field research, Santa Marta was governed by a complex set of actors with overlapping responsibilities. The top half of the hill was under the jurisdiction of the state of Rio, while the bottom half was under the jurisdiction of the city of Rio. Some state institutions like the UPP had authority over all of the favela, while some municipal services like trash collection were active at the top of the favela. The UPP captain was visible infrequently, showing up to meetings that had to do with public safety, promoting

\footnotetext{
${ }^{1}$ In 2010, 1 dollar $=\sim 2$ reals. In 2012 during my field research, the minimum wage had been raised to 700 reals per month.
} 
the image of the UPP in the community, or disputes between different factions living in Santa Marta. In the beginning of the UPP program in Santa Marta in 2008, the UPP captain handled all disputes and mediated between residents and the state, much like a colonial administrator. In effect, the UPP captain had taken the place of the dono do morro or local leader of the drug trafficking organization that used to control Santa Marta. As Brazilian citizens, favela residents had the right to vote, but under the martial law powers of the UPP they were not given full civil rights when it came to drug trafficking investigations, public assembly, and land tenure. After a while this arrangement began to tax the UPP captain, who was not used to such an administrative role that involved adjudicating every community dispute or grievance. ${ }^{2}$ As a result, responsibility for mediating with the urban policy apparatus was delegated to the residents' association and a few municipal programs designed to integrate favelas into the municipality of Rio. The residents' association acted as the mediator between residents and the state especially regarding the urban interventions that I observed during my field research. While the residents' association did not have regular meetings, the residents' association was noticeable on a weekly basis via the loudspeaker system throughout the favela that was used to announce events, the president's position on political issues, and job notices. Residents formed committees and called meetings for issues like water shutoffs and tram outages, and the president of the residents' association attended those meetings. The Peak Committee was formed in 2011 to mobilize on the issue of the

\footnotetext{
${ }^{2}$ Interview with the coordinator of the United Nations Habitat division in Rio.
} 
resettlement program for Peak residents and those were the residents that I interacted with the most.

\section{Overview of fieldwork}

In August of 2010, I carried out preliminary field research in Rio for two weeks, including a visit to Santa Marta to attend a community meeting between residents upset about a ban on parties in Santa Marta and the UPP captain. I also verified access procedures to two different archives and visited potential host institutions for my field research including Pontifical Universidade Catolica (PUC-Rio) and Justiça Global.

I began my fieldwork in November of 2011. I stayed in a hostel in Botafogo for a brief period, then rented a room in an apartment building inside the favela boundaries along the road from the stairs of the favela to Sao Clemente Street, one of the main thoroughfares of the middle class neighborhood Botafogo. My research contacts from FGV, the eventual host institution for my visa, were in the process of carrying out a research project in Santa Marta on citizenship and discrimination in Rio’s favelas, so I began accompanying them on their field interviews and attending their analysis sessions at the FGV. I did this for two months as they wrapped up their interviews and then in January of 2012 I moved to a favela residence about two thirds of the way up the hill after a Santa Marta resident and tourist guide with the municipal tourism program in Santa Marta helped me arrange lodgings guide. Initially I slept on the floor in the living room of a four room family residence, and later moved to the lage (roof) or top of the self-constructed building where residents often enjoy their leisure time. My host used my rent money to finish the addition to their family residence on the lage, where he intended 
to move in the future after I left. I lived there for about three months until I became sick and moved to a residence at the bottom of the hill where the roof was less leaky.

Life at the top of the hill had been quieter, the air was cleaner, and the view was spectacular as I awoke each day to roosters crowing or the residents' association loudspeaker making announcements. I did not need to descend and climb the hill every day for work, so I did not experience the difficulty of climbing the hill as did residents that worked in other neighborhoods. I gained a sense of the rhythm of everyday life, standing in line to use the tram as residents complained about tourists. I trudged up nearly two thirds of the roughly 800 steps to the top of the favela when the tram stopped working, sometimes carrying groceries. I saw the effects of the rains on the stairs and the deposits of trash that were left after the rains. After moving to the bottom of the hill, I stayed with Natalia, a master's student in geography at the Universidade Federal de Rio de Janeiro who had carried out oral history interviews with elderly residents in Santa Marta and also worked at the community radio station of Santa Marta. Natalia's residence was right behind the Quadra, or dance hall/community building, where the Samba school held its practice sessions. While this was an interesting attraction, it made sleeping difficult as three or four days a week there were loud music events until three or four in the morning followed by samba practice sessions at different hours of the day during the week. The bottom of the hill was more active, events were usually held either in the Quadra or the Padre Veloso health center constructed in 2009 in front of the park on São Clemente. The Urbaniza meetings I attended were usually held at the top of the hill, meaning that I needed at least 20 minutes advance notice for the often unscheduled meetings. I began training at the martial arts center known as the Quadrinha as a way to 
become familiar with the community. The martial arts center, run by a resident known as Pescado or Fish Catch, was a small mat room about half way up the hill with windows onto the main path through the center of the hill. There were many children and adolescents that attended the classes at the martial arts center, so I quickly became known to the children playing in the alleys between favela residences throughout the favela. Being known in the favela was helpful for avoiding potential problems and for gaining access to new research participants.

\section{Participant observation}

I used participant observation during my time living in Santa Marta, focusing on public meetings, community events, and also on resident organizing practices (Hay 2010; DeLyser et al. 2010; Emerson, Fretz, and Shaw 2011). During the meetings or events in Santa Marta, I took notes on the proceedings, while occasionally asking questions for clarification. Santa Marta residents were very accustomed to researchers and taking notes did not attract much attention. I also took notes on my experiences living in Santa Marta and my changing understanding of my field research. I provide more detail on my field research activities below. After my preliminary research in 2010, my field research proceeded in four phases:

The first phase was during November and December of 2011 when I was searching for a place to live in Santa Marta while also accompanying Dr. Fleury's research team during their interviews with Santa Marta residents. They conducted interviews primarily in the lower part of the favela, the park in front of Padre Veloso center, and in the bar along the road to the two main entrance points to the stairs that 
climbed the hill of the favela. They carried out some interviews at the FGV campus. On two occasions, we also visited a school in the center of the favela and an event near the Peak. By attending these interviews, I gained a quick overview of the social organization of the favela, key figures, and the internal politics of different groups in Santa Marta. Dr. Fleury had frequented Santa Marta decades before carrying out research there and thus had pre-existing relationships with some of the older residents.

The second phase was in the first three months of 2012 when I moved to lower part of the Peak, in a home about halfway between the fourth and fifth stations of the tram. There I was able to observe daily life and the rhythms of the Peak. I attended several Urbaniza meetings while living on the Peak, and thus qualified as a "resident" in the eyes of the other residents. Clearly I was an outsider and a foreigner at these meetings, but this positionality actually helped my relationship with the Peak residents since I was not a government representative and was not involved in internal favela politics. In fact, I was welcomed by the Peak residents who attended these meetings because they viewed me as a check on ability of the state to intimidate residents or make claims that were later denied. Certain Peak residents referred to me jokingly as their "secret weapon". Because many of the Peak residents felt that the residents' association neglected their situation, there was a tension between the residents' association allies and the Peak Committee. My association with the Peak residents could have caused difficulties with my access at the residents' association, but I had other contacts through the tourism program with strong ties to the residents' association so I was able to navigate the internal politics problem well enough to carry out my research. The third phase was from April until November of 2012 when I lived at the bottom of the favela 
with Natalia and continued attending the urbanization meetings and undertaking archival research in the city center. My twelve month visa expired in early November 2012, so I returned to Miami. The fourth phase was from September to December of 2013 when I returned to Rio to conduct follow up interviews and archival research. I was unable to find a place to live in Santa Marta again, so I rented a room nearby in Botafogo. During this time I attended inter-favela anti-removal meetings in Santa Marta, the nearby favela of Tabajaras, and one meeting to contest removals in Tabajaras at the prefecture.

Early in my field research, I visited Santa Marta and arranged a guided tour at the municipal tourism kiosk, a pilot project for favela tourism initiated in Santa Marta. After talking with the supervisor and explaining that I was doing research on the eco-barrier, I was recommended to take the tour with one particular guide who was critical of government projects in the favela. After taking the tour on November 4, 2011, I asked about renting a place in the favela and was informed that would be difficult as there were people waiting for openings already. I returned to talk with residents every week while accompanying Dr. Fleury's team on their interviews and was not able to find an available place. Another contact in Santa Marta that I had arranged from Miami was also unable to help me with a place to rent. I later learned that certain influential residents were resistant to gringos renting in Santa Marta, as they did not want to push out residents that needed cheaper rent to work near Botafogo. One member of Dr. Fleury's research team arranged another contact near the top of the favela that helped me look at a place near the fourth station of the tram, but the owner did not want to rent to a single male because she had bad experiences with immigrant workers from the Northeast. I was unable to rent a place on the hill of Santa Marta until January of 2012 when the tour guide discussed above 
rented me his addition-under-construction. Once I had moved to Santa Marta, I began my participant observation in earnest, eating meals with my host and watching telenovelas with his family. I was still attending Dr. Fleury's research analysis sessions at the FGV, so two times a week I went down and up the hill.

It was also in January that the urbanization meetings began, and my participant observation in urbanization and community meetings held in Santa Marta forms the core of my field research. I decided to focus on the meetings for three reasons. First, they were public meetings that were often recorded by video camera or residents using their cellphones, meaning that the participants were aware they were being recorded and that my audio recordings were another recording of a public meeting. After accompanying Dr. Fleury's team in Santa Marta, I realized that many favela residents were reticent to discuss politicized subjects while being recorded for interviews, due to the fear of unknown repercussions from the state and other residents. Residents were also only recently relieved in 2008 from the control by armed drug traffickers who used the "law of silence" as a means to avoid police actions, punished by death. Accordingly, audio recording of private interviews without a pre-existing relationship was not a simple matter in Santa Marta. Second, the meetings were a rich source of perspectives on the urbanization project with residents from different political perspectives, vocations, and parts of the favela. The participants in these meetings were primarily concerned with communicating their concerns to the meeting organizers and other residents. This meant their performances in the meetings were political communications of their concerns and goals and that I was observing the interaction of the state's attempt to implement its project with the residents' political communications. Thirdly, the meetings were a good 
place to recruit residents with particular perspectives for interviews and identify who the key state actors were for later interviews. Many of the government employees refused, as they had instructions from their employers not to speak to researchers or the press. I was able to speak to several government employees off the record and interview several former government employees who were quite insightful.

In community meetings that were not recorded in public, like the contralaudo, tourism, tram, and inter-favela anti-removal meetings, I jotted down notes and then made an audio recording of those notes plus all of the details I could recall shortly after the meeting ended. Later I would ask other meeting attendees about details that I could not recall and ask about their recollections of the meeting in interviews. Dr. Fleury's team used a similar method with multiple people attending an interview and then postinterview we would reconstruct the interview using multiple recollections. Since I kept a voice recorder on my person, there were several times that I had incidental discussions with residents that were important to my research where I used my voice recorder immediately following the discussion to recapitulate the conversation. After I had moved to the bottom of the hill in April, I would check the Quadra daily for meetings that had slipped by unnoticed by my research contacts. On several occasions I sat in on events arranged by the UPP, like visits from public figures and events intended to improve the relations between the UPP and residents. I also made frequent trips to the fifth station to speak to Peak residents and occasionally I would find poorly advertised events in process on the soccer field. I also attended other non-research related Peak events like birthday barbecues, the monthly Por de Santa samba party, and cultural events that were held on the Peak. 
It is important to note that my presence possibly served a political purpose for the Peak Committee that I did not understand, either within the Peak Committee or between the Peak Committee and the residents' association. My presence could have altered the tone or content of the Urbaniza team running the meetings, they may have been more careful about complying with the laws regarding resettlement or allowed residents more leeway than they would have without my presence. Furthermore, my presence may have emboldened the Peak Committee to be more confrontational with the Urbaniza team and GeoRio. I told the Peak Committee that I did not need to know their plans for counteracting the resettlement in advance, that I did not want to somehow harm their efforts or give away anything they were doing, but that I might ask about it after the fact. I also told them that it was better that I did not appear to be an activist in the meetings because government employees would be more open with me about their project. I also advised the Urbaniza team that I was not a journalist and they would not wake up and find coverage in the newspapers of anything I recorded during the resettlement meetings. Table 1 presents the meetings, dates and number of people in attendance. 
Table 1: Summary of meetings attended in the favela Santa Marta

\begin{tabular}{|l|l|l|l|}
\hline Meeting attended & Location & Date & Attendees \\
\hline $\begin{array}{l}\text { Community meeting on party } \\
\text { ban with Captain Priscila. }\end{array}$ & $\begin{array}{l}\text { Cantao Plaza at } \\
\text { bottom of favela }\end{array}$ & August 2010 & 20 \\
\hline $\begin{array}{l}\text { Santa Marta: o morro e sua } \\
\text { gente book release. }\end{array}$ & $\begin{array}{l}\text { Daycare center } \\
\text { at the bottom of } \\
\text { the favela. }\end{array}$ & Nov. 6, 2011 & 50 \\
\hline $\begin{array}{l}\text { SOS from the Peak/Raiz do } \\
\text { Santa }\end{array}$ & $\begin{array}{l}\text { Soccer field at } \\
\text { the fifth station }\end{array}$ & Dec 10, 2011 & 30 \\
\hline $\begin{array}{l}\text { General Assembly on } \\
\text { Urbanization Project }\end{array}$ & Quadra & Jan 17, 2012 & 200 \\
\hline $\begin{array}{l}\text { Urbaniza resettlement } \\
\text { committee (seven meetings) }\end{array}$ & $\begin{array}{l}\text { UPP outpost on } \\
\text { east side of the } \\
\text { Peak. }\end{array}$ & $\begin{array}{l}\text { March-June, } \\
\text { August-October } \\
\text { 2012 }\end{array}$ & $10-15$ \\
\hline $\begin{array}{l}\text { GeoRio area of risk } \\
\text { presentation }\end{array}$ & $\begin{array}{l}\text { UPP } \\
\text { headquarters at } \\
\text { the fifth station }\end{array}$ & July 3, 2012 & 40 \\
\hline Contralaudo & $\begin{array}{l}\text { Community } \\
\text { building at the } \\
\text { fifth station }\end{array}$ & July 25, 2012 & 10 \\
\hline $\begin{array}{l}\text { Favela beautification } \\
\text { meeting with Coral. }\end{array}$ & $\begin{array}{l}\text { UPP station at } \\
\text { the bottom of } \\
\text { the favela. }\end{array}$ & August 2, 2012 & 10 \\
\hline Hike Against Removals & $\begin{array}{l}\text { Trail from Santa } \\
\text { Marta to Dona } \\
\text { Marta viewpoint }\end{array}$ & $\begin{array}{l}\text { September 2, } \\
\text { 2012 }\end{array}$ & 30 \\
\hline Cantao Plaza & June 2012 & 5 \\
\hline Land titling meeting & Quadra & March 2012 & 100 \\
\hline Bondinho meeting (2) & $\begin{array}{l}\text { Quadra \& Laje } \\
\text { Tande Firmino }\end{array}$ & $\begin{array}{l}\text { March 29 \& } \\
\text { April 14 2012 }\end{array}$ & $5-10$ \\
\hline
\end{tabular}

\section{Access and interviews}

Through my contacts in the municipal tourism program and residents I met while accompanying Dr. Fleury's research team in the fall of 2011, I was introduced to key members of the Peak Committee that was organizing a response to the resettlement program for residents of the Peak that desired to remain in their homes. These key Peak Committee members contacted me to attend the urbanization meetings, Peak Committee 
meetings, and other social events held on the Peak so that I was familiar to residents of the Peak that attended the public meetings on urbanization. I recruited interview participants through the public meetings. I interviewed thirty three residents of Santa Marta using a semi-structured interview format, twenty of which were residents of the Peak, and fourteen non-residents, four of whom worked for the state of Rio and five of whom worked for the city of Rio. After learning that the United Nations Habitat division had a role in coordinating the UPP-Social, I also interviewed the coordinator at the United Nations Habitat headquarters in Cosmo Velho. I interviewed the Santa Marta residents after events and meetings either at the event location or at their homes, as they preferred. I interviewed some employees of the city and state of Rio at events and some in the health building at the bottom of the favela. I recorded most of the interviews with government employees, but a majority of the Peak residents preferred not to be recorded so I took notes and after the interview, I used my voice recorder to recall as much of the interview as possible. I have changed the names of all the Santa Marta residents to protect their identities except the president of the residence association, which is a publicly held elected office recognized by the Rio municipal government. I did not change the names of government employees who spoke at the public meetings.

\section{Participatory action research techniques}

While my methods are not framed as a Participatory Action Research (PAR) project, I used several techniques from the PAR toolkit (Pain 2004; Hay 2010). Focusing on area of risk in Santa Marta as my topic forged a stronger relationship with the Peak residents and the Peak Committee since it was of greater concern to them than the ecobarrier. Many residents viewed the ecobarrier as a nuisance and waste of tax dollars, but 
it had not resulted in any substantial organization within Santa Marta, while the area of risk resettlement project did. I redirected my research focus based on the issues that residents thought were more important, which is one of the hallmarks of PAR (Hay 2010). While I was in the field, I researched the legal constraints for the resettlement of favelas and the specific laws that applied to Santa Marta's geography and its history of urban interventions, the clauses on adverse possession in the Organic Law, and the Forest Code. I discussed my findings with the Peak residents and discussed contradictions in the urbanization project, considered alongside interventions in other favelas of Rio.

I also attempted to benefit my research community to "decolonize" my field research (DeLyser et al. 2010). The Peak Committee notified me of coming events and recent occurrences and I shared my archival research findings, my developing understanding of the project and the guidelines for the laws that Urbaniza needed to comply with during the resettlement. Behind the scenes I helped them with composing slogans and promotional material. I shared the aerial photographs I purchased from the prefecture archive showing a portion of Santa Marta that was removed in the 1970s, which contradicted the state's claim that Santa Marta had never suffered a removal. I have not shared the conclusions of my research because I had not yet made them during my field research but plan to when I next return to Rio de Janeiro in spring of 2017. To help shape media coverage, I also wrote an article on my research findings for RioOnWatch, a website that seeks to correct misconceptions and stigmas surrounding Rio's favelas in the media and by researchers. I distributed this article, which was more accessible, to the Peak residents in hard copy and via Facebook to several pages widely read by Santa Marta residents in the Fall of 2013. 
I knew from my interactions with residents that Facebook was the most widely used form of social media in Santa Marta, which had wireless access near the tram stations, and that a large proportion of residents had access to the internet and used Facebook. In addition to writing for the online media, I also acted as a guide and interpreter for a Guardian reporter working on a story about favela evictions in Rio. When I was contacted by RioOnWatch to guide a German photographer named Marc Ohmref-Leclef working on a project in Rio's favelas, I acted as an interpreter and explained the situation facing the peak residents. The photographs that Marc took in Santa Marta and other favelas threatened by displacement were put on an exhibition in New York City and Rio de Janeiro, and were later published as a book, Olympic Favela.

\section{Archival research}

I carried out archival research for the following three themes regarding Rio de Janeiro: 1) the history of favela removal discourses and laws that prohibited favela expansion; 2) the history of reforestation and the discourse of land use conflict between favelas and the urban rainforest; and 3) the emergence of DRR discourse and the risk mapping of favelas. I examined the following types of documents: urban planning documents from the municipal and state governments of Rio, government documents from the dictatorship on favela removals, park management documents from the national park in Rio, urban planning and disaster management documents published by the World Bank, newspaper articles on state programs to control favela expansion and the critical responses, aerial photos of land use changes in Rio, and historical photos of Latin American cities from the personal collection of an architecture professor. I researched several key primary documents during my field research and examined a significant 
number of secondary sources in Brazilian scholarship published in Portuguese. The key primary documents I examined in the city of Rio de Janeiro included: a 1969 government document on favela removals and resettlement published by the Coordenação da Habitação de Interesse Social da Área Metropolitana (Coordination of Habitation of Social Interest in the Metropolitan Area) located in the Biblioteca Nacional; Rio's 1992 Plano Diretor (Master Plan) for urban planning located at the Arquivo da Cidade; the 1981 Plano de Manejo: Parque Nacional Da Tijuca (Tijuca National Park Management Plan) located at the Instituto Brasileiro de Geografia e Estatística (Brazil Institute for Geography and Statistics); and aerial photos of the favela Santa Marta from 1974 and 1985 located at the Centro Administrativo São Sebastião (Prefecture of Rio de Janeiro). I also located a mid-1970s image of Santa Marta in the Eric Dulhosh special collection of architecture slides from South America at the Florida International University library.

I was already familiar with the major archives in Rio-the Biblioteca Nacional, Açervo Nacional, and CPDOC/FGV—from my participation in the Foreign Language Area Studies program in Rio before my fieldwork, but as my fieldwork progressed and my themes became more recognizable I visited two more specialized archives-the Instituto Brasileiro de Geografia e Estatística (IBGE) and the Arquivo da Cidade do Rio de Janeiro - to research the activities of the Instituto Brasileiro de Desenvolvimento Florestal (Brazilian Forest Development Institute) in the Tijuca National Park and Rio's urban policy that divided urban space into different sectors for urbanization or environmental protection. Brazil is one of the most internet connected countries in the world and so online sources in Portuguese like the Instituto Pereira Passo's website host a plethora of studies, reports, indexes, and interactive maps. This provided me a more 
recent picture of the changes in Rio's urban policies for favelas. Table 2 summarizes the sites and topics of my archival research and findings.

Table 2: Archival research summary.

\begin{tabular}{|c|c|c|c|}
\hline Archive & Topic and findings & Decade & $\begin{array}{l}\text { Time } \\
\text { Spent }\end{array}$ \\
\hline $\begin{array}{l}\text { Biblioteca Nacional do } \\
\text { Brasil }\end{array}$ & $\begin{array}{l}\text { Primary and secondary sources on } \\
\text { government programs for favela } \\
\text { removals, history of reforestation, } \\
\text { national park management. }\end{array}$ & $\begin{array}{l}\text { 1960s- } \\
1980 \mathrm{~s}\end{array}$ & $\begin{array}{l}\text { One } \\
\text { week }\end{array}$ \\
\hline $\begin{array}{l}\text { Açervo Nacional do } \\
\text { Brasil }\end{array}$ & $\begin{array}{l}\text { Secondary sources on government } \\
\text { programs for favela removals, history } \\
\text { of reforestation, national park } \\
\text { management. }\end{array}$ & $\begin{array}{l}\text { 1960s- } \\
1980 \mathrm{~s}\end{array}$ & $\begin{array}{l}\text { One } \\
\text { week }\end{array}$ \\
\hline $\begin{array}{l}\text { Arquivo da Cidade do } \\
\text { Rio de Janeiro }\end{array}$ & $\begin{array}{l}\text { Primary and secondary sources on } \\
\text { government programs for favela } \\
\text { removals, history of reforestation, } \\
\text { national park management. }\end{array}$ & $\begin{array}{l}\text { 1980s- } \\
2000 s\end{array}$ & $\begin{array}{l}\text { Three } \\
\text { days }\end{array}$ \\
\hline $\begin{array}{l}\text { Prefeitura do Rio de } \\
\text { Janeiro/Centro } \\
\text { Administrativo São } \\
\text { Sebastião }\end{array}$ & Aerial photos of Rio's favelas. & $\begin{array}{l}\text { 1970s- } \\
1980 \mathrm{~s}\end{array}$ & $\begin{array}{l}\text { Two } \\
\text { days }\end{array}$ \\
\hline $\begin{array}{l}\text { Fundação Getúlio } \\
\text { Vargas/ Centro de } \\
\text { Pesquisa e } \\
\text { Documentação de } \\
\text { História Contemporânea } \\
\text { do Brasil. Rio de Janeiro }\end{array}$ & $\begin{array}{l}\text { Secondary sources on the history of } \\
\text { urban policy and planning for favelas. }\end{array}$ & $\begin{array}{l}\text { 1920s- } \\
1990 \mathrm{~s}\end{array}$ & $\begin{array}{l}\text { One } \\
\text { month }\end{array}$ \\
\hline $\begin{array}{l}\text { Instituto Brasileiro de } \\
\text { Geografia e Estatística/ } \\
\text { Rio de Janeiro }\end{array}$ & $\begin{array}{l}\text { Primary sources on the management } \\
\text { of Tijuca National Park. Secondary } \\
\text { sources on reforestation. }\end{array}$ & $\begin{array}{l}\text { 1960s- } \\
1980 s\end{array}$ & $\begin{array}{l}\text { Two } \\
\text { days }\end{array}$ \\
\hline $\begin{array}{l}\text { Eric Dulhosh special } \\
\text { collection at the Green } \\
\text { Library of Florida } \\
\text { International University }\end{array}$ & $\begin{array}{l}\text { Primary source, images of favelas in } \\
\text { Rio de Janeiro. }\end{array}$ & 1970s & $\begin{array}{l}\text { One } \\
\text { day }\end{array}$ \\
\hline Online newpapers & $\begin{array}{l}\text { Favela removals, reforestation, } \\
\text { "greened" favela control policies, and } \\
\text { disaster management. }\end{array}$ & $\begin{array}{l}\text { 1960s- } \\
2010 s\end{array}$ & $\begin{array}{l}200 \\
\text { hours }\end{array}$ \\
\hline World Bank online & $\begin{array}{l}\text { Primary and secondary documents on } \\
\text { World Bank financed projects for } \\
\text { disaster management in Rio de } \\
\text { Janeiro. }\end{array}$ & $\begin{array}{l}\text { 1980s- } \\
1990 \mathrm{~s}\end{array}$ & $\begin{array}{l}20 \\
\text { hours }\end{array}$ \\
\hline
\end{tabular}




\begin{tabular}{|l|l|l|l|}
\hline $\begin{array}{l}\text { Instituto Pereira Passos } \\
\text { online }\end{array}$ & $\begin{array}{l}\text { Rio's urban and environmental policy } \\
\text { studies. }\end{array}$ & $\begin{array}{l}1990 \mathrm{~s}- \\
2010 \mathrm{~s}\end{array}$ & $\begin{array}{l}40 \\
\text { hours }\end{array}$ \\
\hline PEEP/FGV & $\begin{array}{l}\text { Records of interviews with Santa } \\
\text { Marta residents by Dr. Fleury. }\end{array}$ & $2010 \mathrm{~s}$ & $\begin{array}{l}40 \\
\text { hours }\end{array}$ \\
\hline
\end{tabular}

\section{Chapter summaries}

In chapter two, I use a genealogical approach to critically review the green governmentality literature and articulate it with two emerging strands of literature in Human Geography, urban biopolitics and disaster biopolitics. I then assemble these literatures into the framework I use to analyze greened favela control measures in Rio de Janeiro. To make the articulation of these literatures, I examine Foucault's lectures from Rio de Janeiro on the biopolitics of towns in different historical moments of Europe in order to argue that Foucaultian biopolitics has two articulation points for my research in this dissertation: 1 . The public health discourse embedded in the practice of urbanism in Rio de Janeiro's history before 1980. 2. The discourse of disaster risk reduction that emerged in the urban policy apparatus of Rio de Janeiro in the 1980s, which includes contributions from the World Bank. Landslide risk mapping, calculated using assessments from geology and meteorology, is a key political technology of the discourse risk reduction discourse in Rio de Janeiro. At the end of the chapter, I layout an analytic of assemblage and governmentality for analyzing the embodiment of these discourses, understood as including practices, and resident responses in my field research from Santa Marta.

In chapter three, which is where the bulk of my archival research is presented, I review the history of the displacement of Rio's favelas and the discourses of risk 
deployed by the urban policy apparatus during different periods. These discourses framed favelas as objects of control policies and programs that resulted in favela displacements, that is to say removals and resettlements. New favela construction was banned by law in under the Building Code of 1937. Favelas were framed as threats to public health and morality in the 1920s, as sources of communist insurgency in the 1960s, and as threats to Rio's forest cover and sustainability in the 1980s and 1990s. Major displacements of favelas occurred in the 1960s and 1970s during the military government (1964-1985), while programs to improve favelas in the 1990s and 2000s partially displaced "upgraded" favelas using a political technology called the ecolimit. I argue that area of risk discourse for favelas emerged in the 1980s, but it did not fully coalesce and align with a state wide program of resettlement until 2010. Related to area of risk discourse is the history of major landslide events and the torrential rainfalls that preceded them. I discuss how after a historic rainfall and landslide event in 1966, an institution was created to respond and mitigate disasters in Rio called The Geotechnical Institute, currently called GeoRio. I reconstruct how GeoRio was critical for the emergence of risk mapping in Rio in the 1980s, both as a qualitative practice and as a quantitative practice, and I trace the emergence of risk mapping as a political technology to set the stage for chapters four and five, which are primarily based on my fieldwork.

Chapter four begins by recounting the controversy over the construction of the ecobarrier in Santa Marta and the response in Brazil and abroad to the green "apartheid" segregating favelas from nature. This controversy shows a narrative of favelas as populations associated with drug trafficking and deforestation, and as such Rio's elite are threatened by the apparent expansion of favelas. I then turn to the urban upgrading 
program in the 2000s and the different ways that program attempted to control favela expansion, especially the socio-legal technology called the "ecolimit". I show how political technology of area of risk emerged along with the ecolimit and then superceded it to become the primary form of favela spatial control in Rio. I then turn to the Morar Seguro resettlement program for favelas mapped as high risk areas and relate it to the resilience biopolitics of disaster risk reduction measures. Turning to how this program was materialized in Santa Marta, I recount the general assembly meeting of Santa Marta's residents where the state of Rio's urbanization and resettlement plan was divulged, as well as the reforestation of the upper portion of the favela known as the Peak. Moving back to the early 2000s, I reconstruct the history of resident organization to urbanize Santa Marta and the collaborative effort between residents and an architect that worked for the state to design a new urbanization plan for Santa Marta. This provides the context for the meeting in October of 2011 where residents prepared for the coming urbanization intervention, since they were aware of the state's plan to displace and resettle the Peak. I then turn to the resident responses to the presentation of the urbanization plan at the general assembly that I witnessed during my field research and the implications with my research.

Chapter five begins by recounting a series of meetings held on the Peak to prepare residents for resettlement. These meetings were run by a public private firm called Urbaniza that was contracted by the state to carry out socioeconomic surveys, register residents for social programs, and fulfill the participatory requirement of expropriation under Brazilian urban land use law. I recount how those meetings were conducted and how the residents responded in those meetings by contesting the area of risk technology 
used as the discursive base for the resettlement. In response, the state brought the head of the municipal firm called GeoRio that carried out risk assessments in Santa Marta until 2009 to explain why the Peak was a risk area. I observed that residents challenged the risk assessment and asked why the state was able to mitigate risk for state construction in different areas of Santa Marta, but was not able to do so on the Peak. I then present three different episodes of resident counterdiscourses to the area of risk political technology, first, the response during the GeoRio risk presentation meeting, second, the production of a counter assessment of risk in Santa Marta, and third, a resettlement awareness raising event called the "The Hike Against Removals" where residents and activists hiked through the favela to the Dona Marta viewpoint above the Peak of the favela, reachable only by a rarely used trail which passed through the ruins of a previous removal from the 1970s. I then analyze these different counterdiscourses using a four part typology I derived from the biopolitics and governmentality literature: visual, historical, participatory, and technical counterdiscourses. 


\section{Chapter II: Biopolitics and the Assemblage Framework}

In this chapter, I articulate the literature that I am building on to examine the resettlement process for residents of Santa Marta mapped as "areas of risk" for landslides. Using the interdisciplinary governmentality and biopolitics literatures, I assemble a framework that I use to analyze the ways that the landscape of Santa Marta is made visible and "rendered technical" for the simultaneous the management of landscape risk and resettlement of Santa Marta's residents. Specifically, I carry out a critical review of the green governmentality literature and then analyze three emerging branches of the biopolitics literature in political ecology- urban, disaster, and conservation biopolitics. This articulation of urban biopolitics as political ecology opens up new space in urban political ecology, which is dominated by Marxist and the new materialism/ontology approaches. ${ }^{3}$ Discourse of disaster risk has become an urban issue, especially in the developing world, since that discourse is increasingly applied to the informal urbanity in the global south.

This dissertation examines how "area of risk" has become a naturalized category and a biopolitical technology in Rio de Janeiro for favela and landslide risk management. While my research is engaging with the green governmentality literature reviewed by Rutherford and Fletcher, Collier has recently critiqued the tendency of governmentality studies to use governmentality as a master category for the technologies of power

\footnotetext{
${ }^{3}$ While there is not space here for a full review of the urban political ecology literature, see (Braun 2005; Keil 2005; Swyngedouw and Heynen 2003; Swyngedouw and Heynen 2003; Heynen 2013) for an overview.
} 
conceptualized by Foucault (S. Rutherford 2007; Fletcher 2010; Collier 2009). In response, I articulate here how I am both building on the body of literature encompassed by the label of green governmentality, with a specific emphasis on biopolitics, and taking account of the insights of Collier into the changed methods that Foucault used in his later work. ${ }^{4}$ In brief, Collier argued that Foucault shifted away from treating any particular technology of power (sovereignty, discipline, biopolitics) as the logic of government for a specific period or progression of phases and instead began looking at the "problem spaces" opened up after existing configurations of power in crisis were critiqued by particular thinkers of the period. Instead of the master category of governmentality as the one ring that ruled them all, Collier calls attention to the way that Foucault conceptualized his analytics of power as reconfigurations, such that any one analytic of power could be the primary analytic at work, even while the others disappeared, complemented, or produced conflicting power relations. Collier called this new way of thinking about the later Foucault's methodology a "topology of power".

Following the feminist political geographer Secor, I push back against Collier's use of a metaphor imported from mathematics (topology) to conceptualize the new approach to Foucault's methods (Martin and Secor 2014). Even so, Collier's critique shows a rereading of Foucault's methodology that cannot be ignored. Foucault's genealogical method problematizes objects of inquiry like the "environment" or "space" and historicizes their emergence by examining the historical record as if their present

\footnotetext{
${ }^{4}$ I submit that Foucault did not abandon the analysis of governmentality in his later work, The Birth of Biopolitics is primarily a genealogy of liberal governmentality in the sense of political economy, but his method did change (Foucault and Burchell 2008).
} 
meaning is not a categorical universal through history. This method is attentive to the possibility that the same objects of inquiry can be re-signified, in other words change meaning over time. Following Collier, my use of genealogy also pays attention to how present discourse assemblages are predicated on the critiques of previous discourse assemblages, opening up new "problem spaces" that enable a variety of responses. Genealogy was used by Foucault to critique the de-politicization of institutions and discourses, in doing so it shows how alternatives to the current power relations are possible. In The Birth of Biopolitics, he relates that his method shows "how the coupling of a set of practices and a regime of truth form an apparatus (dispositive) of knowledgepower that effectively marks out in reality that which does not exist”' (M. Foucault 2008, 19). Foucault's genealogical method is an excellent critical approach to analyzing the emergence of biopolitical technologies like "area of risk", which is what I have attempted to carry out in this dissertation. By using a genealogical approach to critique area of risk as a naturalized category, I examine how area of risk obscures power struggles within Santa Marta over land claims and the creation of protected areas. Below I present how the concepts of genealogy and assemblage provide a way to analyze reconfigurations of power and the connections between analytics, while avoiding the naturalization of governmentality as a master category of Foucault's analytics of power. Primarily I am using Foucault's analytic of biopolitics, so in what follows I will articulate my reading of biopolitics and how I use it in my case study.

To contribute to the emerging literature on biopolitics in Cultural Geography and the wider field of Political Ecology, I emphasize how biopolitics can be used to analyze state interventions in socio-environmental relations between what I call micro- 
populations, the built environment, and changing geological formations (Legg 2005; S. Rutherford 2007; P. Rutherford and Rutherford 2013). By micro-populations, I mean the groups of people differentiated from the larger population via a biopolitical intervention to normalize that group. Normalization is a term Foucault used for biopolitical projects to change or exclude portions of a population as a means to promote the health of the larger population (Michel Foucault et al. 2007). This is different from the normalization of disciplinary power, which normalizes according to standards of performance. By normalization I mean designating certain groups in a population as objects of governmental intervention, which then has the goal of "normalizing" the population by disciplining the designated group, displacing it, or reconfiguring its built environment with the goal of improving the health of the larger population and restoring the circulation of goods, information, and people. To address the complex aspects of biopolitics involved in my case study, I pull out three different branches from the literature on biopolitics in Geography and Anthropology: urbanization, disaster management, and conservation. In what follows, I review the interdisciplinary literature on green governmentality and biopolitics to present how I am making a contribution to the emerging literature on it, particularly in political ecology. I read this literature through an analytics of assemblage woven into a biopolitical conceptual framework, adopted from Tania Li and Stephen Legg (Li 2007b; Legg 2005). Next, I show how I am using Foucault's analytics of power.

Foucault's analytics of power and green governmentality

For the sake of clarity, and rather than reproducing another history of the emergence of governmentality or biopolitics after sovereignty met with crisis, here I 
specify how I am using the terms sovereign power, disciplinary power, and biopower. ${ }^{5}$ Briefly, sovereign power is the power to take life and seize property according to the legal authority held by the sovereign. Sovereign power is exercised whenever the law assigns a penalty, sends in the police, or limits action. Disciplinary power, or what Foucault called the microphysics of power, can be distinguished by three aspects. First, disciplinary power is exercised by controlling the distribution of bodies in space, that is to say by reconfiguring the built environment such that fewer resources are required to control the bodies in question. Second, it is exercised by surveilling those same bodies from a center of control, while at the same time creating the impression of continuous surveillance. Thirdly, it is exercised by conditioning bodies through routine activities and drills. Biopower can be distinguished from disciplinary power in that biopower is exercised to improve the health of the larger population, which is predicated on managing resources and minimizing threats to mortality, while disciplinary power is a more intensive control over smaller groups (Elden 2007b, 2). Biopower allows the circulation of bodies, resources, and information to promote the health of the larger population, which is itself an artefact of census and demographic research. By monitoring key attributes of the population, calculated via statistics using ranges presumed to promote the welfare of the population at large, biopower manages life at the scale of generalities. Biopower used statistics and mapping technologies to make populations legible for government, first at the urban scale and later for the state (Michel Foucault et al. 2007). Having distinguished these concepts analytically, I issue the caveat that in the field of

\footnotetext{
${ }^{5}$ See Collier 2009.
} 
research, each of these technologies of power can work in tandem with each other or in conflict with one another.

While governmentality is not a master category, as a mode of power it can be distinguished by the specific forms of its exercise. Governmentality arose with the emergence of national populations and economies, and the larger scale problems of government and political economy they produced. Governmentality is exercised by defining the proper level of control; intervening enough to sustain political rule, but not so much that its control is counter-productive. ${ }^{6}$ Under governmentality, power is productive of new subjectivities. This line of analysis is what led to the green governmentality literature, to analyze new subjects produced from "environmentality" (Agrawal 2005; Luke 1995). The "environment" was a lacuna that has become widely governmentalized after Foucault's death, although there is some basis in his writings to address the environment (see Darier 1999). While socio-natural relations were not an area of concentration for Foucault, he did develop points of articulation for green governmentality studies, which push governmentality beyond the institutions and scales that he concentrated his research on (S. Rutherford 2007; Darier 1999). ${ }^{7}$ In the paragraphs below, I discuss the work of scholars that have deployed Foucault's governmentality analytic and applied it to discourses of nature and the environment.

\footnotetext{
${ }^{6}$ Several scholars that produced work on green governmentality before Collier's critique used concepts related closely to biopower- i.e. calculation and populations. See Demeritt 2001, Braun 2000, and Luke 1995.

7 The emphasis here is to use a genealogical approach attentive to reconfigurations of power relations in response to critiques by embodied thinkers, the emergence of new technologies, and contingent difference.
} 
Since I am engaging with the green governmentality literature, I will proceed with a critical review of that literature, with close attention to the emerging literature on biopolitics in urban geography and political ecology. In contrast with much of the green governmentality literature that examines how responsibility for environmental management and care has been transferred to communities and individuals from the state, in this dissertation I examine how the state has directly intervened in favelas to green its risk mitigation strategy for landslides and control space or territory (Elden 2007a;

Fletcher 2010). ${ }^{8}$ In my research, favela residents are not being disciplined to self-manage, rather they are conducted and pressured to be resettled from their living space to make way for a reforestation project that is projected to be walled off from the favela. I argue that while this is a form of "will to improve", it is not a form of "responsibilization", as Tania Li calls the devolution of responsibility in neoliberal governmentality, nor is it a form of Agrawal's version of "environmentality", whereby indigenous subjects internalize discourses of conservation and self-manage conservation spaces (Li 2007b; Agrawal 2005). The assemblage I am analyzing problematizes favela expansion into forested areas classified as "conservation areas", which are discursively framed as a risk mitigation strategy for landslide risk, meaning that the displacement of the rainforest by favela space is claimed to increase landslide risk and the replacement of rainforest is thought to decrease risk. In other words, favela residents are being pressured by the state to sacrifice living space for reforested space as a part of a strategy to manage landslide risk and produce new protected areas for conservation. The discursive framing of favelas

\footnotetext{
${ }^{8}$ See Fletcher 2010 for a summary of research that uses the 'environmentality' approach to analyze the increasing neoliberal nature of conservation schemes.
} 
as threats to conservation areas shows that favela management has become a form of “green governmentality”.

The growing body of literature organized under the label "green governmentality" has emerged to critically analyze how socionatures are shaped by and shape rule in different political configurations (S. Rutherford 2007). Contemporary political ecology has fruitfully used Foucault's governmentality analytic in research on histories of land use, biodiversity conservation, and the subsumption of the environment into neo-liberal forms of rule (Watts and Peet 2004; Peet, Robbins, and Watts 2011). Green governmentality can be considered in relation to the contemporary analytic of biopolitics as a means to diagram how these approaches can be productively applied to environmental protection and risk discourses. In Security, Territory, and Population, Foucault writes about early examples of an emergent biopolitics involving the imbrication of human life, climate, disease, and the built environment (Michel Foucault et al. 2007, 37-38). Climate and disease were transformed into risks to the welfare and biological requirements of the population, meaning that they were now artifacts of biopolitical regulation.

Green governmentality emerged as a frame of analysis after scholars began to critically analyze the sustainable turn in development studies (S. Rutherford 2007). The green governmentality literature expanded as scholars examined the shaping of rural or indigenous subjects by governments, conservation organizations and international financial institutions. Green governmentality analyzes the power relations and production of subjects arising from environmental discourses and practices (West 2006; Darier 1999; 
Agrawal 2005; Brand 2007; Luke 1995; Li 2007a; Michael Goldman 2001).

Environmental discourse, like the discourse of development, is a discourse that produces a certain kind of subject legible to technocrats and agents of the state through an environmental lens (Darier 1999; Demeritt 2001; Escobar 1998; Escobar 1996). There are multiple forms of environmental discourses, of which the most prominent are ecological modernization, biodiversity conservation, and sustainability. Ecological modernization has reached the point where it is a dominant discourse for the urban landscape and national economies, giving it the appearance of a social truth (Harvey 1996, 377-383; P. Rutherford 1999, 111). Biodiversity conservation forms another branch of environmental discourse that has been addressed from the standpoint of a green governmentality analytic in Anthropology and Geography (Biermann and Mansfield 2014; Demeritt 2001; S. Rutherford 2007; Agrawal 2005; West 2006). Sustainable discourses circulated by international institutions have produced green governmentality effects for the developing world, opening new lines of analysis of what Luke called “environmentality” (Michael Goldman 2005; Luke 1995; Agrawal 2005; West 2006).

In the first version of environmentality, Luke introduced the concept of geopower, expanding on Foucault's analytic of biopower (Luke 1995:67). Geopower takes global ecology as its domain instead of the population, mediating the relations of humanity with resources that are referred to as the environment (biodiversity, forest cover, air quality, water quality, etc). The concept "environment", as Luke points out, has historically been loaded with both the connotation of surrounding and that which must be protected and policed (1995:64). According to this framing, the discursive construction of the globe, as the "environment", calls for the policing of all things environmental, with the objective of 
enhancing the productivity of global resources. This process requires environmental knowledge and statistics to calculate and measure the forces of degradation and the impact of global environmental management. Environmental science emerged even as the environment was socially produced in ever more differentiated and historically contingent ways (Luke 1995). Goldman has written how environmental science was put into practice as a knowledge of government by the World Bank (Michael Goldman 2005).

Goldman's work on the adoption of green knowledges and practices by the World Bank is also attentive to the historically specific production of nature and territory (Goldman 2001). According to Goldman, green discourses, as truth regimes, generate new relations of power as they translate the objects of development into eco-subjects governed by new regulations and ethical principles. Goldman critiqued how environmental science was put into governmental practice as an authoritative discourse that produced new eco-zones. These new eco-zones remapped the sociopolitical relations of property rights imbricated with the politics of land and resource use, as well as the forced resettlement of the previous inhabitants of conservation areas. Conservation is a state practice that seeks to create uninhabited or green spaces, though state rule over these territories can be contested in the form of land occupations and squatter settlements (Neumann 2001; West, Igoe, and Brockington 2006). Discourses of pristine wilderness often accompany state efforts to establish conservation areas and 'return' landscapes to their natural state, but the displacement that results is a form of cultural violence (Neumann 1998). In chapter five, I relate how programs designed to control favela expansion have the effect of producing new conservation areas and how risk is 
naturalized by state projects to resettle favelas. Goldman writes that displacement can be seen as an effect of modernistic development projects like dams and canals that the World Bank funded in the global south after the 1950s (Michael Goldman 2005). In the case of Santa Marta, the World Bank is funding risk area interventions and government project housing for the poor. These interventions articulate conservation with risk area management, for which the World Bank has provided specialist knowledge since the 1980s.

Goldman deployed a green governmentality approach to critically analyze a World Bank development project in Laos, where the World Bank adopted discourses of the environment to implement its projects and used environmental scientists to produce the authority for that intervention (Michael Goldman 2001). Goldman writes on the crucial role that science plays in generating relations of authority for World Bank projects by muting criticism about the rushed planning and ill-considered consequences of large development projects, a process that has similarities to the favela resettlement programs in present day Rio de Janeiro (Goldman 2001: 514).” This was accomplished in the Laos case, in part, by the selection and vetting of in-house scientists that produced studies confirming the viability of the specified project. By simulating the critical review process, the World Bank stifled criticism and generated legitimacy by following the accepted procedures for implementing its projects. "Authoritative science" also enabled these interventions by problematizing the affected populations in terms of their "needs and deficiencies (Goldman 2001: 503)." Goldman calls attention to the way that criticism has shifted from the lack of planning in the World Bank to the way that impact assessments are carried out pro forma, and thereby politicizing the practice of science- 
for-hire. When writing about development projects predicated upon social and environmental assessments, critical scholars from political ecology examine the natures produced by the practice of science as it is harnessed by different organizations and institutions for development and conservation interventions (West 2006; Li 2007a; Peet, Robbins, and Watts 2011). At this point I return to how Foucault formulated his conception of biopolitics, since it shows the relationship between the production of authoritative knowledge and the reconfigurations of urban renewal.

\section{The emergence of urban biopolitics}

Foucault gave his first lectures on biopolitics in Rio de Janeiro, where he used genealogy to analyze how medicinal biopower arose as a form of state knowledge to improve public health in the emerging state of Prussia. The nascent public health of the time included an observation system, calculation based on data gathering in health facilities, medical "police”, and a bureaucracy (Foucault and Faubion 2001: 142-151). In contrast, France developed social medicine in relation to problems emerging from the intensification of urbanization (poverty, disease, revolt), and as part of the efforts to modernize urban centers and control hygiene with nascent medical knowledge (Michel Foucault and Faubion 2001, 142-151). The socio-environmental dimension of biopolitics appeared in Paris, where efforts to control urban problems were thought to involve the circulation of air and water, as well as the arrangement of the city itself in terms of disposing of trash, corpses, and the milieu of the urban population. Milieu, in the writing of Foucault, meant the built environment of humans that was always a potential source of emergent threats to human life. During urbanization in Paris, poverty became an object of biopower, as the newfound urban problems were claimed to originate in the hovels of 
Paris. To control the sources of health problems and epidemics, a centralized administration and knowledge production system was created for the urban form modeled after the military model of disciplinary power, now oriented towards power over life that sought to control the putative causes of medical problems of that period to the urban population. ${ }^{9}$ Foucault argued that social medicine had socio-environmental concerns in the form of its analysis of water, air, respiration, and the conditions of life (Foucault and Faubion 2001:149). As a precursor to scientific medicine and microbiology, urban medicine was the "medicine of things... of the living conditions of the existential milieu" (Foucault and Faubion 2001:150). The watchword of urban medicine during that period was the notion of "salubrity". Foucault argued that efforts to foster salubrity in the urban built environment were entangled with a number of environmental issues, which I review below as I articulate urban biopolitics with the calculation of territorial qualities. ${ }^{10}$

The governmental technology of public health was created to control salubrity and modify the built environment to both foster life and prevent harm. "Salubrity was the material and social basis capable of ensuring the best possible health for individuals" (Foucault and Faubion 2001:150). Paris was reconfigured to ensure that waste water did not contaminate drinking water after medical knowledge identified water as a vector for pathogens like cholera and malaria. Urbanists believed at the same time that air was a significant pathogenic factor of public health, so air circulation became an object of

\footnotetext{
${ }^{9}$ Lack of air circulation was thought to produce 'miasmas' that caused disease in pre-microbiology medicine.

${ }^{10}$ Salubrity has been used historically to justify favela displacement, and I even observed its use in my field research in 2012.
} 
biopolitical control in the center of Paris. Urban spatial reconfiguration was the prescription, with special attention to living spaces that were diagnosed as insalubrious like the hovels and slums built along the fringes and hillsides of Paris. "Due to overcrowding and the high price of land during the Middle Ages, some houses were built on the gradients. So it was thought that these houses were preventing air circulation above the streams and retaining the humid air on the slopes: they were systematically torn down (Michel Foucault and Faubion 2001, 148)." Authorized by the specialized knowledge of urbanists, slums were demolished by municipal workers with the object to open up avenues and to improve the air circulation and salubrity of the city. This was a discourse and practice that was reflected in South American cities like Rio de Janeiro, Sao Paulo, and Buenos Aires in the early 1900s (Outtes 2003). Similar arguments are currently being made in the ongoing resettlements related to risk area management in present day Rio day Rio de Janeiro. The geographies of urban biopolitics have developed new technologies of government since then, but the emphasis on the urban poor and control over prime living space continue in the present day. Next, I turn to the literature in geography on biopolitics in urban settings to show how new technologies have reconfigured urban biopolitics.

There is a growing body of scholarship in human geography that analyzes biopolitics in urban settings (Bakker 2013; Brand 2007; Braun 2014; Legg 2006; Legg 2008; Outtes 2003; Zeiderman 2013). These scholars have used biopolitics as an analytic for the politics of state interventions that attempt to control urbanization, slum growth, and construct the infrastructure needed to manage the health of urban populations. Legg wrote on the history of the colonial state in India and how it deployed biopolitics to 
control "urban congestion" that viewed slums as sites of disease propagation and immorality (Legg 2006). Legg pointed to the importance of mapping for colonial intervention to control outbreaks of diseases, which were found to be in the most congested areas of the city, in practice this led to urban interventions, often targeting slums for evictions or resettlement. Outtes' account of the biopolitics of $20^{\text {th }}$ century urban planning in the cities of Brazil and Argentina shows that discourses of hygiene and the organic metaphor for the health of cities produce governmental interventions that targeted slums and favelas (Outtes 2003). Practitioners of what was called the "science of urbanism" saw themselves as doctors of the health of the city rooting out disease and moral decay in the growing slums of South America (Outtes 2003). As we will see in chapter three, the practitioners of the science of urbanism were among the first to frame favelas as threats to the health of urban populations in Rio de Janeiro.

In the present situation in the informal settlements of the global south, sewage infrastructure is crucial for the health of urban populations, and it is common for informal settlements in developing states to expand in the absence of sewage infrastructure. Sewage infrastructure, drainage systems, and clean water access are often interrelated, so the health effects are manifold. Bakker examined how the World Bank contributed to biopolitical interventions to upgrade water infrastructure in "developmental states" from the 1960s to the 1980s (Bakker 2013). Bakker's analysis shows that biopolitics produces uneven spaces of infrastructure provision, even for key resources like water that affect the health and productivity of urban areas (Bakker 2013, 283). When micro-populations like favela residents in high risk zones are framed as threats to the health and productivity of the urban macro-population, urban planners and government employees respond by 
making micropopulations legible using technologies of calculation. These technologies of calculation are then enrolled in the implemention of urban biopolitical renovations, which nearly always have displacement effects for vulnerable urban residents. These micropopulations, made legible, are then subjected to resettlement programs and even government organized evictions. In some cases this displacement is proximate, in many it is distant.

Displacement was an effect of the political rationality underlying many urban interventions of the early twentieth century (Legg 2008; Outtes 2003). Infrastructure was crucial for the health of elite urban populations in colonial India, where sewage was not circulated out of urban centers, diseases appeared periodically (Legg 2006; Legg 2008) and a similar series of events related to water management and disease control unfolded in post-colonial Brazil and Argentina (Outtes 2003). The municipal governments and corresponding states controlled the spatial distribution of different socio-economic groups through urban interventions that deployed biopolitical programs in urban cores where elites resided. They chose their areas of intervention based on surveys of income, building structures, and statistics about the frequency of contagious diseases. Calculating the risk of disease produced a truth claim about the congestion of slums and the incidence of tuberculosis, that was then mapped using census surveys (Legg 2008). By using the congestion of the urban population in Old Delhi as a proxy, administrators produced what was effectively a risk map of urban health called an "intensity map". This intensity map was used to calculate congestion as a proxy for the risk of epidemics, which shows how population and disease mapping became technologies of biopolitical government. The urban renovations in Brazil and India were very ambitious in that they prescribed massive 
governmental interventions to produce improved, albeit geographically limited, living conditions that were thought to result in self-regulating subjects. In 1960s Brazil, this meant changing where and in what sorts of structures people lived and even transforming the built environment itself for infrastructure projects and environmental management. While the biopolitical interventions of the early 1900s were oriented towards disease prevention, in the age of increasing climate change and concomitant disruption, urban infrastructure itself is increasingly framed as a biopolitical problem (Braun 2014). The emphasis on urban infrastructure is an effect of increasing concerns about the potential that climate induced disasters could have on coastal cities. These concerns have produced the practice of disaster risk mapping of urban areas as a response. Disaster risk mapping plays a crucial role in the management and displacement of favelas, so in next section I review the literature on disaster biopolitics.

\section{Disaster biopolitics: risk mapping, climate, geology, displacement}

Rather than the risk of disease outbreaks, as I analyzed in the urban biopolitics section, a new form of risk mapping emerged in the 1980s that calculated the risk of disasters in a particular locality, often with poor populations as its object (Munasinghe, Menezes, and Preece 1991). This new form of risk mapping calculated the risk of climate or geologically induced disasters. Zeiderman's ethnographic research in Colombia shows how landslide risk induced by climate and earthquakes has become a governmental technology for the reconfiguration of urban slums and the resettlement of their residents (Zeiderman 2012; Zeiderman 2013). Zeiderman's account of how risk was mapped onto 
informal settlement's in Bogota, normalizing risk by designating certain areas as "zones of high risk", documents how risk is fluid and produced via authority delegated to scientists working for national and municipal governments (Zeiderman 2012). Said another way, the distribution of risk is calculated based on historical and visual surveys of the landscape, and is then rendered technical.

Representing risk in maps is a form of what Tania Li called "rendering technical", that is to say producing a governmental technology for a specific field, while depoliticizing that field from the perspective of the interveners (T. M. Li 2007). These visual representations are themselves subject to temporal changes that accompany the emergence of new technologies for calculating risk and ongoing socio-natural processes. The risk map produced from this process is deployed as a definitive technology for the normalization of informal micro-populations. Informal settlements are often already subject to normalization due to their lack of access to infrastructure, disaster mapping further breaks down their vulnerability and designates certain populations as the most vulnerable of the vulnerable. The prescription of urban planning is often displacement, in Bogota informal residents mapped in a high risk zone for landslides are eligible for resettlement in government housing projects (Zeiderman 2012). Risk mapping provides the visualization necessary for large scale interventions to prepare for and mitigate disaster events like landslides and flooding (Grove 2013a, 581). The calculation of territory as it relates to risk mapping is a form of rendering technical. Risk mapping is predicated on the calculation of territory, by which I mean the historical production of territory in terms of its qualities, which is a form of fixing nature in representations of territory (Braun 2000, 28). 
Understanding risk mapping as a form of territorial calculation provides a path to link biopolitics with socio-nature, in this dissertation I analyze risk mapping of favela territories. Risk mapping is a form of surveying and measuring physical nature as it relates to the calculated life expectancy for people mapped in risk zones, articulating "territory and population together" (Braun 2000, 28). Risk mapping of landslides and flooding uses calculation of the properties of territory to promote health and productivity in human populations, a topic that Braun and Elden have developed in their writing on the calculation of territory using governmentality frameworks (Braun 2000; Elden 2007a). Both Elden and Braun have argued that the historical emergence of territory was neglected by Foucault and that the discursive production of territory is a form of fixing nature. As Braun argues, the emergence of new technologies of geological representation "opened a space, simultaneously epistemological and geographical" that change how the politics and history of communities unfold (Braun 2000, 28). Not only is risk mapping a technology of geological representation with the same effects on the unfolding of history, it is simultaneously a biopolitical technology for managing favela space in Rio de Janeiro. Risk mapping, as we will see in this dissertation, can set in motion a series of events with effects that displace human residents and produce new non-human spaces of forest conservation.

Braun argues that Foucault's conceptualization of governmentality opened the door to scholarship on the ways that representations of nature can produce and be produced by different governmentalities, and one way to analyze the politics of nature into governmentality was by examining the historical production of territory, without assuming its immutability (Braun 2000, 13). How nature is made legible in the qualities 
of territory shows that nature is historically specific when it is enrolled in government (Braun 2000, 15). Braun related how geology, as an emergent science of the qualities of territory, changed both the government of populations and how territory was understood and visualized in nineteenth century Canada (Braun 2000, 28). Geology plays a role in risk mapping as well, by representing and assigning qualities to different topographies, bringing risk and the representation of nature together in assemblages of disaster management. The technique of risk mapping in Rio's urban areas produces evictions as an effect of the displacement that results from landslide risk mapping programs. Landslide risk is calculated using climate science in conjunction with geology, adding climate change to the possible conditions producing landslide risk. Beginning in 1996, the risk managers from the city of Rio have monitored the frequency and intensity of precipitation to calculate landslide risk in the short term, along with historical patterns of rainfall (Geo-Rio 2006). The World Bank now uses climate change as a factor in the calculation of urban disaster risk, since climate scientists expect more chaotic and intense patterns of rainfall in coastal cities like Rio de Janeiro (World Bank 2012b). Here I have articulated the entanglement of geology, climate, and the urban biopolitical management of Rio's favelas. As an effect of disaster risk management in Rio de Janeiro, analyzed in detail in chapters four and five, a novel tactic has emerged whereby risk mapping transforms calculated territory into protected areas (MMA-SBF Brazil 2011). In order to analyze the articulation of risk mapping and conservation, I now turn to the growing literature on biopolitics and conservation, with an emphasis on the ways that power relations produce protected areas and displace residents, in effect producing non-human spaces. 
Scholars that write on the biopolitics of conservation emphasize the calculation of non-human populations and the relations of power that are produced from the protection of biodiversity enabled by that calculation (Biermann and Mansfield 2014; Demeritt 2001; Fletcher 2010; P. Rutherford 1999; S. Rutherford 2007; Srinivasan 2014; West 2006). This literature analyzes the movement of biopolitical techniques from public health, demography and urbanism to disciplines that study the "environment", in this case biodiversity conservation (P. Rutherford 1999; S. Rutherford 2007). Recent work has carried biopolitics to domains of the non-human, in the form of biodiversity assigned particular value by humans for conservation (Biermann and Mansfield 2014; Srinivasan 2014). Techniques used to map human populations like census taking, choropleth mapping, and risk mapping have been transferred to the conservation of forests and species threatened by extinction (Demeritt 2001; Biermann and Mansfield 2014). Demeritt showed how census and statistical calculation was involved in the conservation of forests as a natural resource of the United States government. While this is different from biodiversity conservation for its own sake, which is focused on the protection of key species rather than on sustaining economic exploitation of particular species, Demeritt shows the roots of the movement of these governmental techniques from the biopolitics of human populations to non-human species. The case that I examine in this dissertation is a case where risk mapping of human populations produces spaces of conservation-asrisk-mitigation. I am not arguing that my field research is an example of the calculation of biodiversity for conservation, but rather that it presents the calculation of risk to humans in a way that problematizes the absence of forest cover, what I call "resilience biopolitics" (Darier 1999; S. Rutherford 2007). There are manifold discourses, 
institutional practices, people, and socio-natures imbricated in the resilience biopolitics examined in this dissertation, which following Tania $\mathrm{Li}$, I conceptualize as an assemblage framework. Here I outline my approach to an assemblage framework that emphasizes biopolitics and how I use it to make sense of the different discourses, practices, strategies, and people that make up the biopolitics of landslide risk in Santa Marta.

\section{Analytics of governmentality and assemblages}

Both Legg and Li have articulated governmentality frameworks that provide conceptual tools for research that are explicitly linked to biopower (Legg 2005; Li 2007b). For my purposes here, the key concepts from Li's work are rendering technical, anti-politics, authorizing knowledge, and the will to improve. Rendering technical refers to the process by which the messy reality of difference is simplified for interventions by the state or NGOs. Anti-politics is an effect of rendering places or communities technical, by framing contentious issues within disciplinary knowledge frameworks that assert necessary programs of action. This framing excludes the objects of interventions from questioning the programs under implementation, or it can create controlled participatory frameworks that solicit input from those impacted by particular interventions but limit the possible options for consideration, both of which are forms of anti-politics (Li 2007b). Authorizing knowledge plays a part in both rendering technical and anti-politics by providing an epistemological basis for claims to expertise, in other words, the right to declare which problems are paramount and to define how those problems will be addressed. All three are involved in what Tania Li called the "will to improve", or efforts to improve the conditions of life for vulnerable or excluded populations according to epistemologies drawn from outside the local context (Li 2007a). Li argues that only 
certain institutions or organizations are recognized as authoritatively having the technical knowledge to carry out improvement projects, which she calls "trustees" (Li 2007a, 6). The will to improve extends to new subjects as history unfolds and new technologies enable the visibility of social or ecological problems, many of which are biopolitical in nature (Li 2010).

The urban geographer Legg has done research using a biopolitical analysis of government interventions in India that is worthwhile to contrast with Li's approach to governmentality. Legg's framework of biopolitical analysis is explicitly oriented towards state interventions, but has similarities to Li's framework (Legg 2005). Legg refers to one trust in India as a "technology of government", made up of the strategies and tactics of an organization created by the state to carry out a biopolitical improvement project. Legg identifies "ways of seeing and representing reality; the practical knowledge of specialists and policy-makers" as crucial forms of "visibility" for state interventions carried out by trustees (Legg 2005, 148). These forms of visibility are underpinned by "episteme", or the forms of disciplinary knowledge (including statistics, economics, and sociology) that made objects like population and risk into categories of visibility using different mapping or diagramming techniques (Legg 2005, 147). Episteme also produce the regimes of truth, or naturalized representations of reality, that are put in into play via different modes of visibility. In the case of this dissertation, the episteme are the different forms of disciplinary knowledge that make landslide risk visible, including geology, meteorology, and urban planning. The process of producing an assemblage of landslide risk in Rio de Janeiro involves multiple authors, technologies, institutions, and bodies. I use an analytic 
of assemblage, borrowed from the version developed by Li, to understand how these different forces and people produce the biopolitics of landscape risk in Santa Marta.

Li's analytics of assemblage examines practices ethnographically rather than limiting governmentality scholarship to showing how certain problems emerged via a particular rationality of government in a textual discourse. She argues that it is important to study how disparate elements come together rather than reifying an apparently fixed articulation in an apparatus. An analytic of assemblage distinguishes between an analytic of governmentality and the ethnography of the practices that are produced by and produce a particular governmentality. Following Li (2007, 267), I use an analytics of assemblage to answer the following questions: How are connections made and kept between parties, techniques, and discourses? What are the effects of contingency on the assemblage? Who apprehends or defines risks and what is the reaction to emergent risks? What situated knowledge produces politics within that assemblage? How does contestation emerge within the assemblage? Through these questions I hope to answer Rutherford's call for more critical and empirical work using governmentality scholarship, namely re-politicizing institutional practices and technologies of government while also paying attention to exclusionary effects in specific communities (S. Rutherford 2007, 302). Rutherford also points to further research on how governmental programs fall short of their stated goals and how subjects reject the discourses mobilized by the power relations they are situated within. 


\section{Conclusion}

In this chapter, I show that the disaster risk reduction program active in Rio de Janeiro forms part of the resilience assemblage, since this particular version of disaster risk reduction is not just focused on improving infrastructure in favelas, the program has actively reconfigured favela settlements towards the end of reducing the number and size of favela settlements. Furthermore, DRR prescribes reforestation as a landslide risk mitigation measure and together with the reduction of favela settlements these measures are designed to reduce the risk of a catastrophic disaster across the city of Rio de Janeiro such that the scale of the disaster does not exceed the capacity of Rio's government to respond and recover from. In order to ascertain where and how many favelas to act upon, that is to say just enough to avoid catastrophe, the government of Rio required new and more detailed assessments of landslide risk and the factors thought to increase that risk like rainfall, slope inclination, and the absence of forest cover. The government of Rio remapped all of Rio's favelas after the rains of 2010 and 2011, and it also installed rainfall meters throughout key points of the city, since high rates of rainfall are one of the strongest indicators used in landslide risk calculation. Following the work of critical scholars of biopolitics (Grove 2014a; Anderson 2010; Collier and Lakoff 2015; B. Evans and Reid 2014), all of these measures together constitute a form of what I call "resilience biopolitics", that is to say the attempt to anticipate and prevent catastrophe by implementing disaster risk reduction measures that both reconfigure the built environment and seek ever more updated assessments of contingent factors rendered technical like climate and geological conditions for risk calculation, without overly taxing the state. In the following chapter, I analyze the favela control discourses that preceded 
disaster risk discourse and from which emerged the "area of risk" political technology at the center of my analysis. 


\section{Chapter III: A History of Favela Control Discourses and Interventions}

The purpose of this chapter is threefold. The first is to show that the twentieth century historical roots of the entanglement of urbanization and favela resettlement programs has import for the ongoing spatial reconfiguration of Rio. As I will show in this chapter, favela growth reflected Rio's rapid urbanization in the early twentieth century, and the alarm raised by this trend contributed to the construction of favelas as Rio's primary social problem. The second is to show that urbanization, as a discourse that called for interventions to improve favelas in Rio, produced a series of contradictory approaches and policies in efforts to construct new urban subjects from favela residents. These interventions were complicated by the onset of Cold War geopolitics in the 1940s, which reframed the poverty of Latin America as a potential source of new communist insurgents in a region the US government considered crucial for its foreign policy (Perlman 1976). The third is to show the relationship between risk discourses embedded in the urbanization project, and the exclusionary conditions that affected how and whether favela residents participated in the urban policy apparatus that carried out favela interventions. This urban policy apparatus enrolled a variety of different institutional actors that included the prefecture of Rio, the Catholic Church, as well as state and federal agencies involved in both habitation and social policy. At different times, resources for favela interventions were drawn from the municipality and state of Rio, the federal government of Brazil, and Alliance for Progress financing, a United States development program for Latin America created after the Cuban Revolution in 1959 
(Benmergui 2012; Brum 2012). In the 1990s, the World Bank financed projects for the urbanization and resettlement of favelas, which I also focus on in later chapters.

The research for this chapter was based on archival research of newspapers, secondary literature in Portuguese and English, and government documents that I carried out in the National Archives, the Fundação Getúlio Vargas, the Institute of Brazilian Geography and Economics, and online digital archives. I examined World Bank documents and the Rio de Janeiro newspapers Jornal do Brasil, O Globo, and Correio da Manha using digital searches. My research was informed by my participant observation in urbanization meetings held in Santa Marta during 2012. Some information was obtained from interviews with residents, urban policy workers, and Brazilian researchers I met in Rio de Janeiro, but the bulk of this chapter comes from archival materials and secondary literature. I also consulted the urban planning archive in the prefecture of Rio de Janeiro to examine changes in Santa Marta's favela space in the 1970s, after learning from Santa Marta residents that a partial removal had occurred during that time period.

Favela control discourses: Health, morality, and anti-communism (1920-1962)

Favelas entered the discourse of Rio's urban planning apparatus in the early $20^{\text {th }}$ century framed as blights on the urban landscape and objects of removal (Fischer 2008; Gonçalves 2013; Valladares 2005). After the razing of tenement housing in Rio's center during the Passos reforms (1902-1906), favelas were problematized as visible elements of Rio's urban landscape by Rio's urban elite, many of whom were trained in the disciplines of medicine and engineering and had participated in the sanitation reforms and urban renovation of Passos (Valladares 2005, 40; Fischer 2008, 35). Rio's elite planned the 
modernization of Rio, which they understood as a civilizing project that would renovate the city according to aesthetic and hygienic principles, and also control the effects of tropical diseases in the urban center, which had ravaged Rio during the late 1800s (Meade 1997; Valladares 2005). As favelas increased in number during the 1920s, a prominent real estate developer and journalist in Rio de Janeiro named Pimenta, began a newspaper campaign against favelas in 1926, denouncing them as damaging to Rio's "natural beauty", spreading "filth and miserable poverty" and as risks to public health (Fischer 2008, 41). Rio's elite began planning a new initiative to modernize Rio at the same time that the campaign to frame favelas as aesthetic and hygienic problems continued through the late 1920 s.

In 1927, Rio's elite contracted the French urbanist and sociologist Agache to create a master plan for the modernization of Rio, who reified the framing of favelas as disorderly, unhygienic, and aesthetic affronts to the senses in his 1930 plan (Valladares 2005, 47). Building on the negative framing of favelas by Pimenta, Agache used his authority as an international urban planner to raise alarm about "the favela problem" and recirculated it to Rio's elites (Valladares 2005, 36). Agache called himself an expert in the "science of urbanism" and used organic metaphors for the city that exploited the medical discourse prominent in Brazil; he diagnosed that Rio's favelas were "permanent threats of fire hazards and epidemics for all the neighborhoods that they infiltrate" and a "leprosy" on the landscape of Rio (Valladares 2005, 47). Despite his efforts, the Agache plan was not implemented, but it later influenced Rio's urban planning in the years that followed, constituting a roadmap for Rio's modernization and reconfiguration, with the razing of Rio's favelas as its centerpiece (Fischer 2008, 38-44). Agache's themes 
reemerged in the 1937 Rio de Janeiro Building Code that codified the un-hygienic framing of favelas in a section titled "Extinction of Anti-Hygienic Habitations", hygiene discourse would be present in the favela removal agenda until the 1970s (Valladares 2005, 52-53). Promulgated to control favela expansion, the 1937 Building Code was the first law that prohibited new favela settlements and improvements to existing favela residences. That prohibition would have powerful and contradictory effects for the growth of favelas.

Also in 1937, the military dictatorship established the Estado Novo (New State) regime, both populist and strongly anti-communist in character, which would change how favelas were viewed, as I will write later in the chapter. After 1937, government policy for favelas shifted to a ban on favela constructions in the 1937 Building Code. The 1937 Building Code installed what I call a socio-legal geography of precarity that shaped future programs for the improvement of favelas and inhibited their conversion to more permanent housing (Burgos 1998, 27). The ban on favelas, and the shortage of affordable housing in Rio's city center, left low income workers with few options and within the reach of Rio's authorities, who knocked down any visible favela settlement near the center of Rio. As an effect of the Building Code, favela residents were under constant threat of eviction and loss of personal possessions. As a result, favela residents sought out ever more precarious and hidden locations to build homes, which often meant on forested hilltops and near flood zones, thereby producing a geography of precarious dwellings (Pandolfi and Grynszpan 2003). I will return to the geography of precarity in chapter 4, when I discuss the ban on housing improvements on the Peak of Santa Marta. 
After the Estado Novo regime ended in 1945, the new government rapidly prioritized the control of Rio's favelas, with the creation of two inter-governmental commissions, one to study the causes of favela expansion in 1946 and the second to plan the eradication of favelas in 1947 (Gonçalves 2013, 143-144). After the communist party showed significant strength in Rio's 1947 elections, communist political organizations were made illegal in Brazil and favelas were framed as subversive threats because of their support for the communist party in those elections (Gonçalves 2013, 145-146). This emergent configuration of anti-favela discourses, combining hygienic and subversive framings of favelas, became a pervasive part of the favela removal policy in the $1960 \mathrm{~s}$ and 1970s.

A popular journalist named Carlos Lacerda capitalized on the climate of communist fear in 1948 and declared the "The Battle of Rio" in a series of opinion pieces that denounced favela radicalism and growth (Gonçalves 2013, 146-147). According to Lacerda, favelas were "places of misery" that fueled both communism and encouraged the police to ignore the rights of favela residents (Gonçalves 2013, 146). Lacerda initially called for interventions to improve favelas to head off the ostensible communist threat, and Rio's government attempted to do just that during the 1950s with the assistance of the Catholic Church. During the 1950s, the Catholic Church was enrolled by the state, via a foundation created by presidential decree, the Fundacao Leao XIII, to prevent a communist insurrection in the favelas, "to climb the hills before the communists descend from them" (Gonçalves 2013, 150). This foundation cooperated with residents and the state to improve conditions, community organization, and services in Rio's favelas, it was the first initiative to improve favelas (Gonçalves 2013, 150-151). The Church organized 
residents and helped them to improve their living conditions, often collaborating with Rio's social services agency. The emphasis on improving conditions for favelas in situ came to an end in the 1960s when a larger and more permanent solution to the favelas was attempted.

Favela eradication: Urbanization as favela displacement (1962-1973)

After the anti-communist Carlos Lacerda was elected Rio's governor on a platform of favela "eradication" in 1960, the emphasis on improving favelas onsite was cast aside (Burgos 1998). This was made explicitly clear in 1962, when Lacerda initiated the creation of an agency Compania de Habitacao Popular do Estado de Guanabara COHAB (Popular Habitation Company of the State of Guanabara) to remove and resettle favelas in Rio (Fischer 2008, 79-80). ${ }^{11}$ From early-1960s until the mid-1970s, massive amounts of governmental resources at the municipal, state, and federal scales were tasked with removing the favelas in the affluent and rapidly urbanizing southern zone of Rio, a period the Brazilian historian Brum has called "The Era of Removals" (Brum 2013). With funding from a United States Aid and International Development program for Latin American development called the Alliance for Progress that was launched after the Cuban revolution in 1959, Lacerda's administration built several large project housing complexes named Vila Kennedy, Vila Alliança, and Vila Esperança (Hope) to the north of Rio from 1961 to 1965 (Gonçalves 2013, 214; (Benmergui 2012). ${ }^{12}$ After the 1964 coup installed a military dictatorship in Brazil, the favela removal policy also received

\footnotetext{
${ }^{11}$ From 1960-1975, Rio de Janeiro was the capital of Brazil and Guanabara was the Federal District.

${ }^{12}$ The state of Guanabara changed Vila Kennedy's name from Vila Progresso after President Kennedy was killed.
} 
national support (Perlman 1976, 200-201). From 1964-1965, Lacerda's administration began a concerted effort to remove favelas in the southern zone of Rio and resettle the inhabitants in the distantly located Vilas that lacked access to municipal infrastructure at that time (Perlman 1976, 230). Favela removals on such a large scale and as state policy were unprecedented, a process that would reach its zenith in the period 1968-1973, when Brazilian federal government resources were directed at the "favela problem" (Gardner 1972).

In 1968 the Brazilian state deployed a mass favela removal policy administrated by a newly created federal agency called Coordenação da Habitação de Interesse Social da Área Metropolitana or CHISAM (Coordination of Habitation of Social Interest in the Metropolitan Area). CHISAM was ostensibly created to manage state and municipal institutions and arrange for state capital to be used for the construction of housing projects called conjuntos (Perlman 1976). Operation Favela, a government document that details the CHISAM program, states the goal of favela removals was to remove their "constitution of the urban and social landscape of a large area of the city, with their marks of destitution, promiscuity, and disease (GEG 1969, 96)."13 Of the southern zone favelas listed for removal in Operation Favela, only Santa Marta (referred to as Dona Marta, the name of the hill), Cantagalo, Babilonia, and Tabajaras survived the CHISAM program. All of the surviving favelas have had removals since 2010 or were under threat

\footnotetext{
${ }^{13}$ The favelas to be removed included "Catacumba, Macedo Sobrinho, Dona Marta, Cantagalo (with its appendages Pavão and Pavão-Pavãozinho), Ladeira Ari Barroso, Babilonia, Pedra do Baiano, Tabajaras, Euclides da Rocha, Tunel Novo e do Parque Proletario da Gavea/Conjunto Hab. Marques de Sao Vincente" (GEG 1969, 96).
} 
of partial removals for resettlement in 2013. There were several steps delineated for favelas on the removal list (GEG 1969, 67):

1. Mapping of family residences

2. Aerial Photography

3. Parceling the favela into sectors of analysis

4. Construction of project housing for resettlement

5. Installation of a technical office that monitored favela activity until the removal occurred.

The elaboration of a socioeconomic file on the residents was crucial as those with the highest incomes were prioritized for project housing, due to the presumed ability to pay the new expenses of living in the housing projects. However, the payments for the new apartments were calculated based on favela residents' incomes prior to their removal, ignoring that incomes for favela residents were location dependent and that transportation costs were significant portions of their total income (Perlman 1976; Valladares 1978). Studies showed that favela residents lacked the income to pay as early as 1970 and reports from the housing projects confirmed that residents were not making payments, yet CHISAM continued with the removal process (Gardner 1972). Displaced residents that were unable to pay often rented, sold, or abandoned the project homes to move to other favelas closer to the city center. This shows that CHISAM's primary goal was the displacement of favela residents from the southern zone of Rio, and not the conversion of favela residents into urbanized citizens. Favela residents did not passively 
go along with the removal scheme, favela organization against removals re-emerged in the early 1960 s.

A favela activist organization that emerged in 1963 to fight the removals begun by Lacerda administration, the Federação de Associações de Favelas do Estado da Guanabara or FAFEG (Federation of the Favela Associations of Guanabara) attempted to organize a majority of Rio's favelas with residents' associations in 1968 against the CHISAM removals and for urbanization (Oliveira 2002; Gay 1994, 20). The political slogan "Urbanization yes, removal never!" was used by favela activists during the 1960s. This slogan shows that favela activists understood at that time that the response to the eradication discourse was the interpolation of urbanization discourse in an effort to gain coeval recognition as urban subjects (Gardner 1972). CHISAM's removal project was accompanied by state deployed anti-mobilization tactics against FAFEG, including torture, disappearances, and imprisonment of activists that organized against favela removals (Valladares 2005, 111). This repression cut short the movement against removals and the CHISAM program removed a majority of the remaining favelas from the southern zone before 1973 (Brum 2013). The political slogan "Urbanization yes, removal never!" was used by favela activists during the 1960s. This slogan shows that favela activists understood at that time that the response to the eradication discourse was the interpolation of urbanization discourse in an effort to gain coeval recognition as urban subjects (Gardner 1972). By the late 1970s, the aggressive favela removal policy proved unfeasible and brought about the realization that favelas were a fixture of the Rio urban landscape. There is strong evidence that real estate and construction interests were used to prioritize the removals, and collective memory in favelas reflects their role in the 
history of favela removals (Brum 2012; Valladares 2005; Perlman 1976). On several occasions during the resettlement meetings I attended in Santa Marta, residents responded to state plans for risk removals by suggesting that a hotel or condominium would be built in the favela space after a removal and that they knew the land where they lived was valuable. ${ }^{14}$

One important historical case that provided ample material for these collective memories and counter-discourses was the attempted removal of the favela Vidigal in 1978. Real estate speculators followed removal policies closely, and they were the main beneficiaries of the removals in Botafogo and Lagoa during the dictatorship period (Fischer 2008, 79-80). After CHISAM and the overt favela removal agenda ended, during 1977-1978 Rio's government attempted to remove the favela Vidigal, which has a spectacular view of the sea. The government justified Vidigal's removal with the imputed risk of landslides, but the government was rebuffed when it came to light that real estate developers were waiting in the wings to build a luxury hotel on the same site (Gonçalves 2013, 263; McCann 2014). The attempt to remove the favela Vidigal in 1978, using the argument that the favela was at severe risk of a landslide, combined both the real estate motive and the risk justification in ways that reflect both my field research in Santa Marta and the contemporary situation that I describe in Chapters 4-5 (McCann 2014, 2).

\footnotetext{
${ }^{14}$ I first observed residents pointing out this contradiction at an anti-removal benefit event on the Peak of Santa Marta on December 10, 2011, it was repeated in the 2012 urbanization meetings I observed.
} 
Figure 3.1: The favela Santa Marta in 1966.

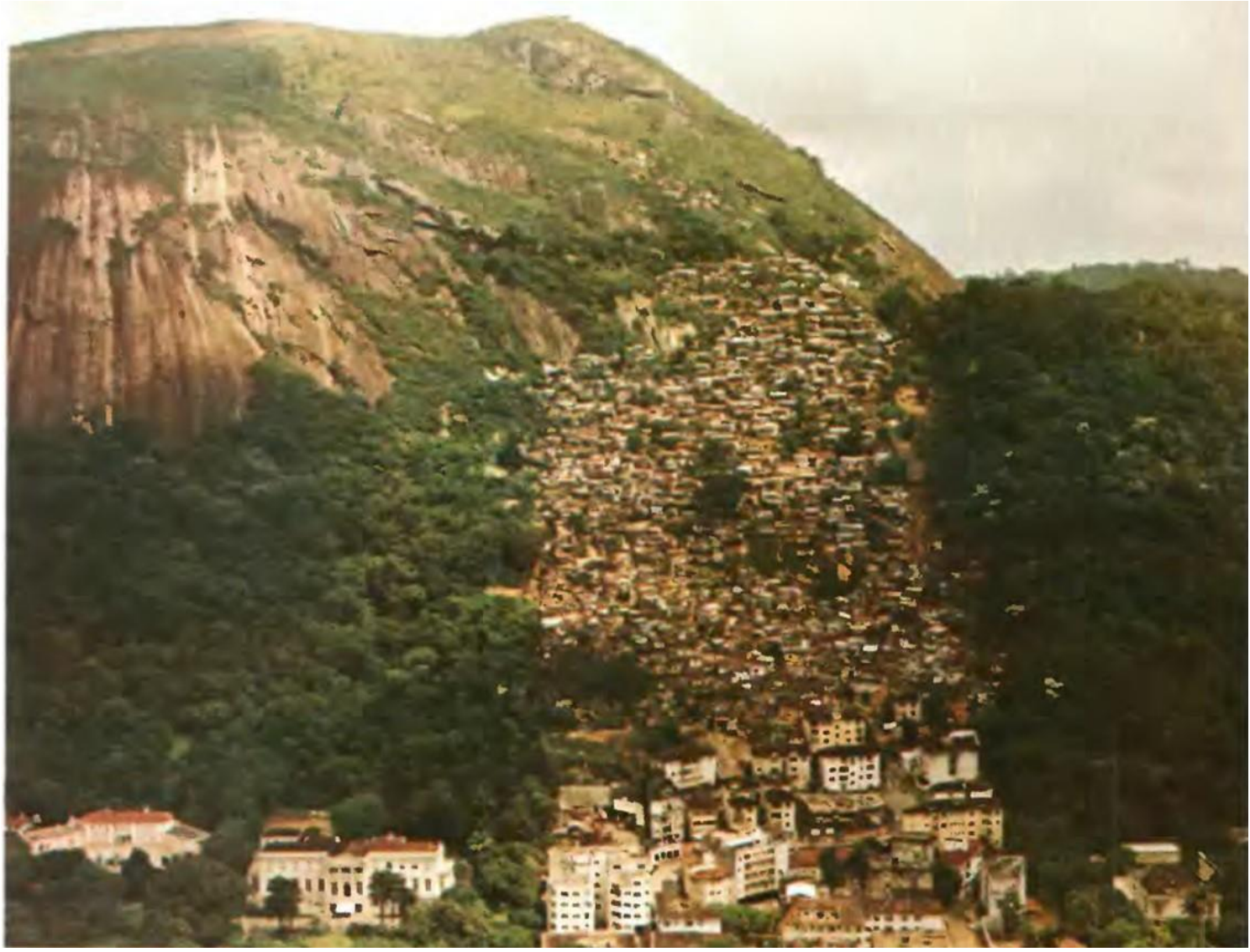

This image shows that Santa Marta's settlement pattern was roughly the same in 1966 as it is in the present and that the Peak was fully settled (Jones 1973).

As with Santa Marta in the 1950s, Vidigal resisted the removal with the assistance of lawyers and activists linked to the Catholic Church, a movement known as the Pastoral das Favelas (Favela Shepherds) (Gay 1994; McCann 2014). Risk discourse was used as a justification for the removal of the favelas Vidigal, Pasmado, Catacumba, and Rocinha during the first wave of favela removals. The method of evaluating the risk of landslides was a "geo-technical survey" carried out by the Fundação Geotécnico of Rio de Janeiro or GeoRio (Geotechnical Foundation of Rio de Janeiro)(Gardner 1972). Founded in 1966 after catastrophic landslides and historic rainfall, GeoRio worked with 
CHISAM during its removals in the early 1970s, arguing that wherever hillsides needed containment works to prevent landslides, the favela must be removed. ${ }^{15}$ Figure 3.1 shows that Santa Marta existed prior to the creation of GeoRio in 1966 and that the settled area was roughly the same as it is in the present, which becomes important in chapters four and five. The relationship between the GeoRio and favela removals will return later in this chapter as I discuss the emergence of risk mapping as a way to control favela expansion. The favela Santa Marta was a key site for the development of risk mapping as a governmental technology, so I now turn to Santa Marta's history with the threat of removal and landslide risk.

\section{Santa Marta: From the threat of removal to threat to the environment}

Despite being marked for removal in CHISAM documents, the favela Santa Marta was among the few favelas in the southern zone that survived the CHISAM removals in the 1970s. In its attempt to remove all of the major favelas in the southern zone of Rio, CHISAM removed the favelas of Macedo Sobrinho, Morro do Pasmado, and Morro da Catacumba, all nearby Santa Marta. As has been documented in the historical literature, the CHISAM program was abandoned by the federal government in 1973 (Perlman 1976; Valladares 2005). A 1969 government document from CHISAM and newspaper accounts in 1972 list Santa Marta for removal by CHISAM before 1974, indicating that CHISAM's plans were interrupted by the dissolution of that program (GEG 1969). ${ }^{16}$

\footnotetext{
15 "Geotécnica e CHISAM estão entrosadas," Jornal do Brasil, April 8, 1971.

"Salgueiro vai perder 50\% de sua área e a Mangueira 35\%," Jornal do Brasil, July 29th, 1971.

16 "Governo remove 120 favelas e da casa a 200 mil pessoas," Jornal do Brasil, January $5^{\text {th }}, 1972$. According to CHISAM, in 1971 Santa Marta was surveyed with 1600 dwellings and an estimated 8000 residents.
} 
While there are multiple explanations in the historical literature for the dissolution of the CHISAM program (Valla 1986; Oliveira 2002; Perlman 1976), it is clear that the National Housing Bank of Brazil decided that CHISAM was a failure in the mid-1970s and stopped financing project housing for favela resettlement, shifting to the more profitable financing of middle class housing during a period where national economic growth was decreasing (Perlman 1976; Nilton de Souza 2009).

The early closing of the CHISAM program explains why not all of the favelas targeted were removed, but this does not explain why some favelas were removed before others. Much of the impetus to remove favelas came from the potential value of the land that they occupied (Perlman 1976). The Morro do Pasmado favela (Removed in 1964 to housing projects financed by the Alliance for Progress) was adjacent to Botafogo beach and had nice view of the bay of Guanabara. Morro do Pasmado and Catacumba are now parks surrounded by high rise condominiums. Catacumba and Macedo Sobrinho (Removed in 1971 to CHISAM housing projects), were located near what is now the affluent Lagoa district, the land they occupied was used to construct upper class homes. According to reports from the Jornal do Brasil, Santa Marta suffered a partial removal in 1971, after strong rains, when fifty barracos (shacks or self-built dwellings) were condemned by municipal engineers and the plan to remove the entire favela was reiterated. ${ }^{17}$ These residents were assigned to project housing in the distant west zone of Rio, a process similar to favelas that were entirely removed.

\footnotetext{
17 "CHISAM decide remover 57 familias ameaçadas na Favela Santa Marta," Jornal do Brasil April 7 7 $^{\text {th }}$ 1971. CHISAM's plan to remove the rest of Santa Marta was reiterated in this article.
} 
Santa Marta's survival of the CHISAM removals was possibly due to strong ties to the Catholic Church in Botafogo, stemming back to the founding of the favela as habitation for workers that constructed the nearby Jesuit run high school and its expansions over a period of 30 years (Pandolfini and Grynszpan 2003, 311; McCann 2014, 57). Santa Marta had a history of resisting evictions with the assistance of the Catholic Church in the 1950s (Fischer 2008; Burgos 1998). Another possible explanation is that the land nearby Santa Marta was not as highly valued for real estate speculation, due to its distance from Praia de Botafogo (Botafogo Beach) and Lagoa (Lagoon, a lake located a short distance inland from Ipanema beach). ${ }^{18}$ Itamar Silva said, without activism and mobilization, Santa Marta would have been removed prior to CHISAM, regardless of the multiplicity of factors that led to its survival of the CHISAM program (Silva 2003). After surviving CHISAM, Santa Marta went on to experience a partial removal of homes inside the boundaries of a nearby national park in 1975 . The history of that national park is important to understand how that removal unfolded and sheds light on land use restrictions that I discuss in later chapters.

\footnotetext{
${ }^{18}$ Lacerda, in his series of articles in the Correia da Manha called the Battle of Rio before he became governor of Guanabara, made a post script remark that Santa Marta was in preparations to be removed and that there was the potential for real estate speculation after the removal. 2005 IPP. Favelas cariocas, um tema comum a Dodsworth e Lacerda Estudos Cariocas. Rio Estudos Janeiro \#144.
} 
Figure 3.2: Santa Marta and Botafogo circa 1975.

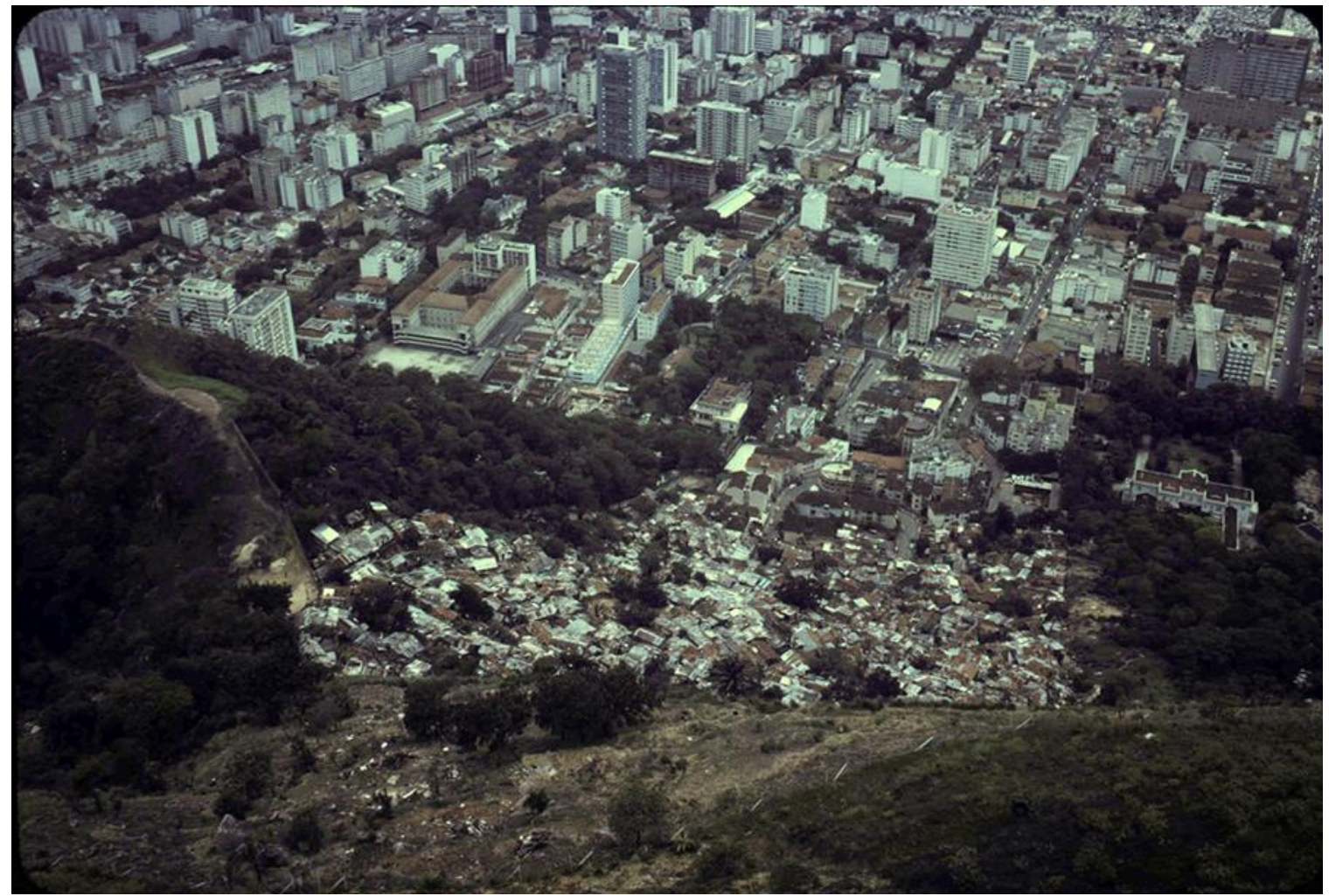

This photo taken from the Dona Marta hill scenic viewpoint was taken prior to the IBDF renovations of the viewpoint and the construction of the drainage system for risk mitigation along the right side of this photo. From the Eric Dhulosch special collection at Florida International University.

Rio's urban expansion began near the Guanabara Bay and has since surrounded a mountainous area called the Tijuca Massif. The portion of this massif above 200 meters has been declared a national park, the Tijuca National Park (TNP), while the area above 100 meters became a protected area that disallowed new settlements in 1965 (IBDF 1981; SMU-RJ 1992). ${ }^{19}$ Created in 1967 from several pre-existing Rio de Janeiro parks, the TNP was administrated by the prefecture of Rio until 1977 when a federal institution, the Instituto Brasileiro de Desenvolvimento Florestal or IBDF (Brazilian Forest

\footnotetext{
${ }^{19}$ Municipal Decree number 322. March 3rd, 1976.
} 
Development Institute) assumed control and set up key access points to generate tourism revenue (IBDF 1981; ICMCBio 2008). The shift in in administration to the IBDF marked a turning point in the enforcement of the parks borders and efforts to reforest the Tijuca Massif. After 1977, the IBDF began preparing the park to charge for tourism, a process that included setting up control points, increasing the number of guards and caretakers, and reforesting deforested or burned off areas of the park near tourist zones. ${ }^{20}$ The placement of favelas along the hillsides of the TNP rainforests has drawn the attention of park administrators, biologists, and geologists who have pointed to the expansion of favelas since the 1980s, which they call favelização, or favelization, as causes of deforestation and crime in the TNP (Netto 2005; ICMCBio 2008; IBDF 1981; IPP 2005; Peixoto et al. 2007). ${ }^{21}$ As a key tourist site that was centrally located in Rio de Janeiro, the viewpoint from the top of the Dona Marta hill was the first area to go through reforestation and renovation during the transition to IBDF control in 1977 (Figure 3.2). The upper portion of the hill Dona Marta that surrounds a key tourist scenic viewpoint was mapped within the TNP in 1967 (IBDF 1981; ICMCBio 2008). Most of Santa Marta was located on the hill Dona Marta below the boundaries of the TNP, but part of the favela extended inside the park boundaries prior to the mid-1970s (Figure 3.3). ${ }^{22}$

\footnotetext{
20 "IBDF trabalha no morro de S. Marta para trazer de volta os passarinhos," Jornal do Brasil, November 11, 1977.

${ }^{21}$ Favelização refers to the expansion in number and size of favelas, as part of the process of rapid urbanization in Rio, many of which are located on hillsides in or near the national park.

22 "Problema de competência," Jornal do Brasil, December 2, 1977.

"IBDF lança projetos de restauração de 76 hectares em duas florestas do Rio," Jornal do Brasil, September 25th, 1977.
} 
Figure 3.3: Comparison of aerial photos of Santa Marta from 1975 and 1985.

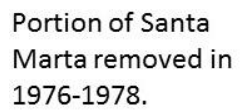

Lefthand side:

Santa Marta 1975

Righthand side:

Santa Marta 1984

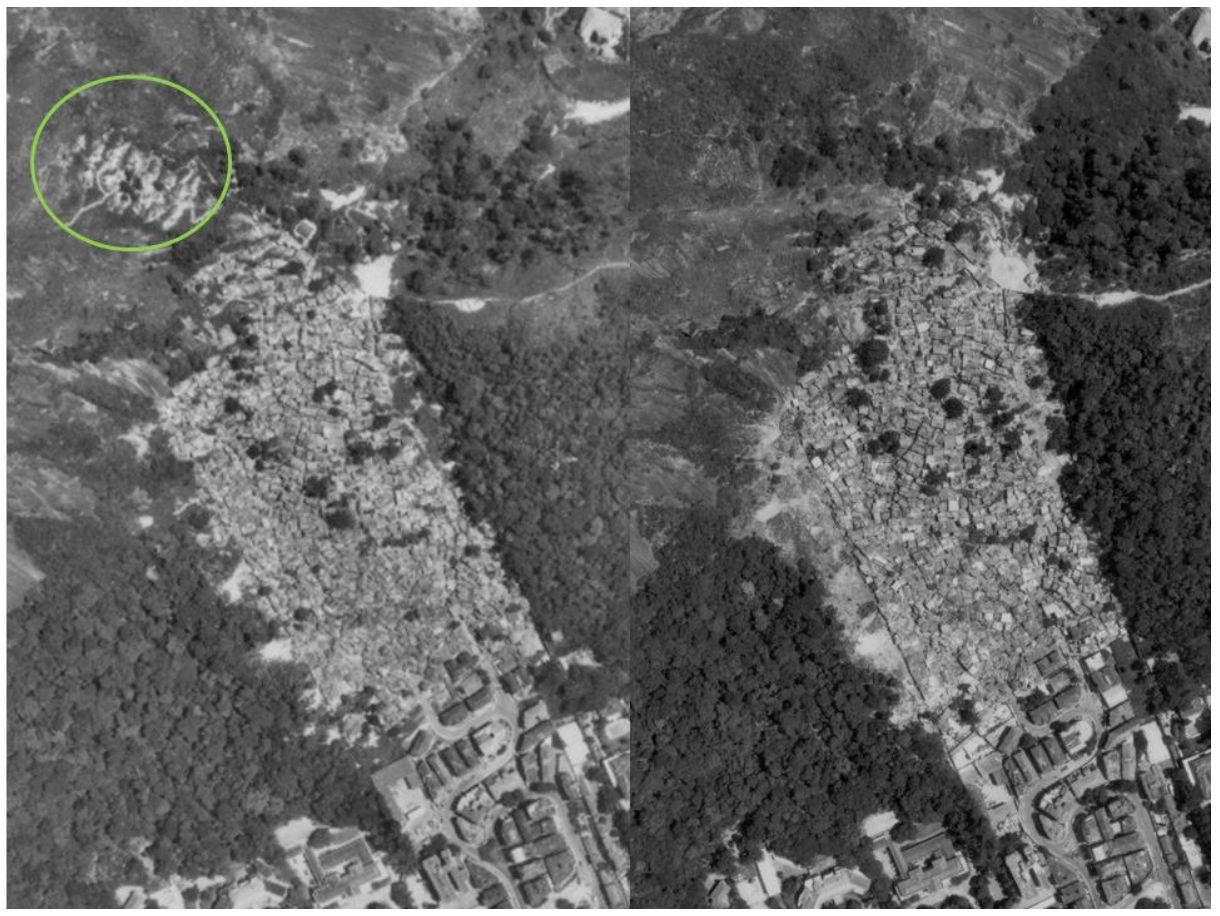

These aerial photos show that Santa Marta diminished in size from 1975 to 1984. Santa Marta is one of the few favelas in Rio that has decreased in area over time, and this event marked the most significant reduction in its area. The portion that existed in 1975 would now be inside the Tijuca National Park. Aerial photos were purchased by myself from the prefecture of Rio de Janeiro archives at the Centro Administrativo São Sebastião. Modifications are my own.

\section{I learned via conversations and interviews with residents that Santa Marta had} experienced a partial removal circa 1977 that was not mentioned in my review of the historical literature (Figure 3.3) ${ }^{23}$ By one resident's account, who lived just below the border of the national park at the time, the guarda florestal (forest guard) waited until the residents had gone to work during the day and then without notice knocked down and

\footnotetext{
${ }^{23}$ Semi-structured interview conducted on October 4, 2012 and open ended discussions with elderly residents during anti-removal events. During this interview, I asked the interviewee about a comment overheard during an anti-removal event in Santa Marta, the Trilha Contra Remoções (Hike Against Removals). I learned from the response that in the 1970s Santa Marta had extended significantly farther up the hill than its current boundaries, into what is now the national park. Prior to this removal, the interviewee estimated that there were around 40 self-built homes that existed above the current limits of Santa Marta. The removal likely happened circa 1976-78 when the IBDF took over administration of the TNP from the prefecture of Rio and began enforcing the borders of the park, which in Santa Marta's case were in the state of Rio de Janeiro's jurisdiction.
} 
destroyed all the wooden shacks. The residents were then forced to move lower down into Santa Marta and stay with friends or relatives. This removal is significant for two reasons. First, it shows that the size of the favela Santa Marta was reduced during the military dictatorship. Second, it shows that the current upper border of Santa Marta was the result of the conservation practices of the Tijuca National Park and efforts to control favela expansion into the national park. It is exactly this linkage between controlling favela settlements and the production of protected areas that I explore in this section.

In the rest of this chapter, I will argue that risk mapping is a governmental technology that controls the extent of favela land use and produces protected areas outside of national parks in Rio de Janeiro. I will show that quantitative risk area mapping emerged in Rio's urban policy for favelas after the 1988 landslide disaster occurred in Rio and the World Bank intervened to finance the disaster recovery. Furthermore, the World Bank financed the urbanization projects for favelas in the 1990s and 2000s, and risk mapping was an integral part of the process. At the beginning of World Bank interventions to mitigate risk in Rio de Janeiro, the emphasis was on framing favelas as objects of intervention rather urban areas or poverty generally. Risk mapping was not limited to favelas, but since favelas tended to occupy land that was not zoned for formal use, risk area mapping of urban areas fell upon favelas almost exclusively. The urbanization projects of the 1990s and 2000s were specifically targeting favelas for upgrading, and risk mapping was mandatory for the implementation of those projects. As I will write later in the chapter, the 2010 disaster risk mapping was carried out for the entire state of Rio de Janeiro, but the displacement effects were concentrated on favelas. Moreover, in favelas founded in the early 1900s like Santa Marta, new Environmentally 
Protected Areas were produced through the program of urbanization for favelas. After the 1990s, urbanization and risk mapping became linked in Rio's urban policy, and later this would have implications with large scale favela removals carried out in Rio de Janeiro after 2010. Santa Marta played a key role in the emergence of risk mapping in Rio’s urban policy in the late 1980s, I will focus on that process in the rest of this chapter.

\section{Urbanization and disaster risk mapping focus on favelas}

Here, I present how risk discourse underwent a change in the mid-1980s that transformed urban policy for favelas in Rio de Janeiro. Flooding and landslides have been part of the history of urban Rio de Janeiro since the colonial period, and favelas increasingly were impacted by these events as the city expanded. Beginning with the founding of GeoRio in 1966, landslide risks were assessed on a case by case basis, usually by laudo de vistoria (onsite visual surveys) after an event had already occurred (Geo-Rio 2005). ${ }^{24}$ The assessment of risk was performed by geologists and engineers working for the city of Rio de Janeiro. This changed in the 1980s, when risk mapping emerged as a technology for disaster management in the developing world, and international institutions began providing resources for the developing world to adopt disaster prevention programs using risk mapping (UNDRO 1984).

After the 1988 landslide disaster in Rio, GeoRio created the first quantitative risk map for the Rio metro region (World Bank 2012a, 79), which was used to map the areas of favelas with the highest risk of landslides. Using quantitative data, Geo Rio mapped

\footnotetext{
${ }^{24}$ Rio de Janeiro suffered a number of landslides in 1966-1967 after extremely severe rainfall, see the United States Geological Survey report (Jones 1973).
} 
the Rio metro area, into low, medium, and high risk, using their archive of site surveys, history of events, and geological data collection in 1988 (Figure 3.4). As one of the favelas most damaged by the 1988 landslides, Santa Marta was among the first favelas that were mapped for risk using qualitative data gathered by Geo Rio (Geo-Rio 2005). ${ }^{25}$ The GeoRisco Project emerged from this risk mapping project for the quantitative calculation of landslide risk, used today for risk and urbanization interventions in favelas in Rio. The 1989 risk map was used for urbanization interventions in Rio de Janeiro financed by the World Bank during the 1990s, which included the well-known favela upgrading program called Favela-Bairro (Slum to Neighborhood)(Fiori and Brandão 2010; Perlman 2010, 275). Active in Favela-Bairro, GeoRio began working on disaster prevention via risk mapping simultaneously as the World Bank and United Nations were also promoting disaster prevention in the developing world, a process that began in 1984 .

\footnotetext{
${ }^{25}$ During the GeoRio meeting with favela residents I attended in July of 2012, a risk map of Santa Marta
} from 1986 was presented as evidence of when GeoRio began working in Santa Marta. 
Figure 3.4: 1988 Landslide susceptibility map of the municipality of Rio de Janeiro.

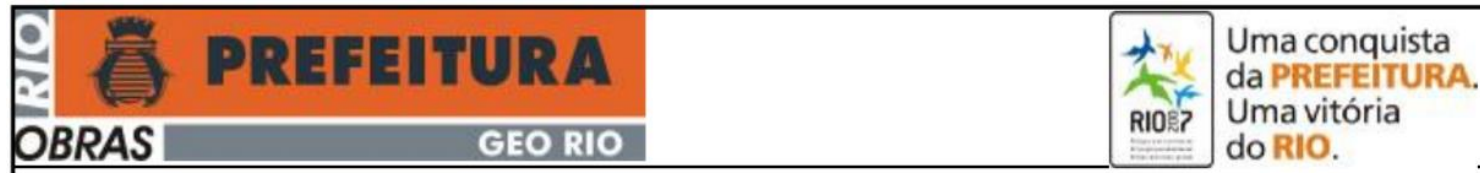

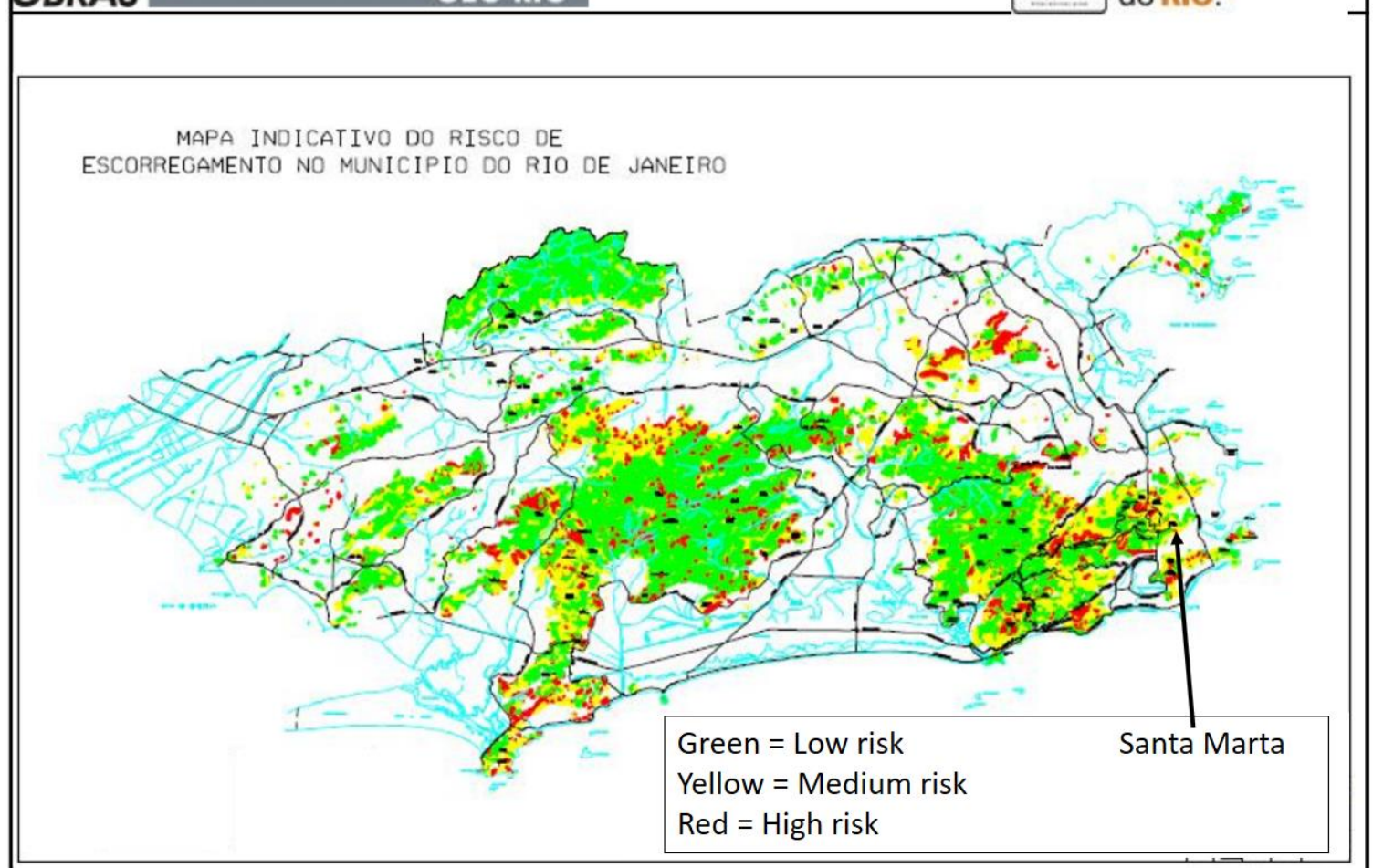

This 1988 GeoRio map "Indicative Map of the Risk of Landslides in the Municipality of Rio de Janeiro" comes from a 2005 municipal document titled "Municipal Risk Reduction Plan: Cartography of Quantitative Risks and Landslides in Sectors of Precarious Settlements in the City of Rio de Janeiro" (GeoRio 2005). This map would be called a susceptibility map today, according to GeoRio criteria. The marking on the top right corner is part of the promotional campaign that the prefecture of Rio used prior to the 2007 Pan-American games in Rio. Modifications are my own.

1984 was a watershed year for disaster discourse, both the UNDRO United Nations Disaster Relief Organization (UNDRO) Disaster Prevention and Mitigation Report (DPMR) on preparedness and Natural Disasters: Acts of God or Acts of Man were published that year (Wisner et al. 2004). The World Bank also began financing disaster prevention projects in 1984 (UNISDR 2013). The DPMR focused on preparedness as a form of disaster prevention, with the developing world as its object of intervention (UNDRO 1984). Disaster risk area discourse circulated to Rio de Janeiro and changed the 
way that favela land use was controlled in very important ways. "Risk area" became the key phrase in urban policy for Rio's favelas after the 1988 torrential rainfall and concomitant landslides that resulted in disaster for Rio, in which 289 people died (Munasinghe, Menezes, and Preece 1991). The term risk area does not specifically denote favela space in urban policy discourse, however, in practice risk area resettlements focus on favelas. Risk area is also used to describe favelas and their surroundings by journalists and state employees that link favelas with homicide rates, often without contextualization (Vaz et al. 2007). As we will see later in the chapter, proposed and enacted displacement and resettlement of favela residents after 2008 has been primarily justified by "risk area" discourse related to disasters in Rio de Janeiro.

"Risk area" emerged in the discourse of Rio's urban policy complex after the intervention by the International Bank for Reconstruction and Development (IBRD) to fund disaster recovery after the 1988 torrential rainfall and the destructive landslides that followed, called the "Rio Reconstruction Project" (Munasinghe, Menezes, and Preece 1991). World Bank documents show that disaster recovery projects were funded from 1989 through 1995 in the municipality and state of Rio de Janeiro, specifically related to recovery from the 1988 landslides and prevention projects in favelas (World Bank 1988; World Bank 1996). World Bank specialists that worked on the planning of the Rio Reconstruction Project linked disaster prevention to risk area assessment, reforestation as a form of risk mitigation, and control of land use that specifically focuses on favelas (Munasinghe, Menezes, and Preece 1991). In a paper co-authored by the chief of the World Bank's Environmental Policy division (Mohan Munasinghe) and the urban planning specialist for Brazil in the Infrastructure Operations Division (Braz Menezes) 
for a colloquium called "Environment and Natural Disaster Management" in 1990, favelas were attributed as causes and consequences for both environmental degradation and increased risk of disasters in their analysis of the 1988 landslides in Rio:

"The severity of the disaster can be attributed largely to the region's vulnerability to natural hazards. Environmental degradation resulting from the unplanned expansion of human settlements, faulty construction, congested drainage, and inadequate maintenance contributed heavily to the event's catastrophic outcome. Poverty was also linked to both the causes and consequences of the disaster. The poor of Rio de Janeiro who live in such high-risk areas as steeply sloping hillsides, landfills, and floodplains became both the perpetrators and victims of environmental degradation. Poverty and poor environmental management continue to place the city's population at risk from natural hazards (my italics)."

Here a key discursive move is laid out. Added to the attribution of poverty as a cause of environmental degradation, this paper argues that environmental degradation increases the risk of disasters to vulnerable residents of informal settlements, meaning that they are to blame for increasing the risk to themselves. Reforestation and forest protection figure prominently in the prescriptions for reducing disaster risk in Rio in this paper, as does environmental planning and education, trash collection and disposal, and landslide mitigation construction. These measures were called for to enhance Rio's "resilience" to disasters of the future, foreshadowing the emerging resilience thinking to urban disaster management that is currently under way. This paper followed the 1988 
disaster response in Rio coordinated by the World Bank, and in the following paragraphs I examine these documents in more detail.

The 1988 planning document for the IBRD's intervention in Rio, based on studies commissioned by the IBRD and performed by Geo Rio, makes the linkage between reforestation, favela expansion, and DRR clear:

"In addition, technical assistance would be provided to prepare a detailed medium- and long-term reforestation plan (para. 9[f]) for the State of Rio de Janeiro including (i) a discussion of the technical, financial, and institutional aspects of the program, (ii) the technical criteria used to justify the areas selected as ones of high risk of landslides, (iii) a description of the State Secretariat of the Environment and its technical and institutional capacity to implement the program, (iv) proposed arrangements for protecting the reforested areas (in particular, for keeping squatters out), (v) a discussion of land tenure issues (if any), and (vi) a schedule for implementing the program (World Bank 1988, 25). .26

The excerpt above shows that the World Bank called for technical criteria to define risk areas in Rio and also provided reforestation as a prescription for both stabilizing slopes and delimiting areas of human settlement with green space, with a special emphasis on controlling squatter settlements. This same document links risk areas with favelas and attributes favela expansion to deforestation:

${ }^{26}$ My italics. 
"This urban growth has occurred in an uncontrolled fashion, due to unenforced legislation, intermittent populist policies, and an accelerated weakening of urban planning institutions during a decade of economic neglect. In the process, the original forest cover has been radically cut back, and squatters have established unplanned human settlements (favelas) which occupy ever-steeper hillsides, often perching precariously above the city below" (World Bank 1988, 12) $)^{27}$

Here urban growth is attributed as the cause of deforestation, but only "squatters" are mentioned and not the developers, behind the rapidly expanding residential developments that also provide employment for the residents of the squatter settlements. $^{28}$ This excerpt shows a framing of favelas as agents of environmental degradation and disaster conditions. Within five years of the writing of the document above and the initiation of disaster recovery efforts throughout Rio state, Rio's municipal urban public policy complex would import the same framing of favelas into its urban policy for favela upgrading projects. The 1996 Implementation Completion Report for the Rio Reconstruction and Prevention Project directly states that the urban interventions to upgrade Rio's favelas that began in 1994 were shaped by the experience acquired through the implementation of the Rio Reconstruction Project. That urban upgrading intervention, which acquired Inter-American Development Bank funding in 1995, was called Favela-Bairro. Favela-Bairro was a Rio municipal initiative with a declared

\footnotetext{
${ }^{27}$ Note that very little of the forest cover in Rio de Janeiro is "original". The hills of the Rio metropolitan area were denuded to produce coffee during the colonial era and the current forest cover was the result of a colonial replantation program using slave labor (Heynemann 1995; Abreu 1992; Freitas, Neves, and Chernicharo 2006).

${ }^{28}$ Barra, the Rio suburb where the 2016 Olympics were held, has been the area most intensely developed in the past three decades (Alvaro Ferreira 2009).
} 
mission of integrating and upgrading favelas into the rest of Rio, to "urbanize" favelas into becoming neighborhoods and citizens of Rio de Janeiro, to become new urban subjects.

Favela-Bairro, launched in 1994, adopted the risk discourse of the 1988 disaster and provided a politico-juridical technology that future urban policy for favelas would redeploy. The most extensive and long lasting program up until that point in Rio's history, Favela-Bairro was also the first Brazilian urban policy project to adopt "risk area" as an operative term (Fiori and Brandão 2010). The risk area discourse was institutionalized by the urban legal framework created to implement Favela-Bairro and Morar sem Risco (Live without Risk), a simultaneous program that resettled favela residents in cases where more than $25 \%$ of the favela was mapped in a high risk area (Fiori, Riley, and Ramirez 2000). ${ }^{29}$ As a result of the Favela-Bairro criteria for upgrading, high risk favelas were excluded from urban upgrading and infrastructure that would have reduced their risk for disasters (Fiori, Riley, and Ramirez 2000). While this framing of urbanization was understood clearly by the designers and those that enacted Favela-Bairro, it was not clear to the favela residents whose parents had fought the CHISAM removal policies with the slogan "No to removals, yes to urbanization!". Put another way, risk area and resettlement became part of the legal and policy discourse of favela urbanization in Rio via the Favela-Bairro project, despite constitutional principles from 1988 giving usufruct rights to longtime favela residents (Fernandes 1995). As part of the urbanization of favelas, Favela-Bairro was planned to control favela expansion and removals of newer

\footnotetext{
${ }^{29}$ This program resettled approximately 14,000 residents.
} 
and smaller favelas on ecologically fragile land in or near urban infrastructure. The legal framework to launch Favela-Bairro began with the promulgation of Rio's 1992 Plano Diretor (Master Plan), as Brazilian law delegated authority to cities for urban development (RioOnWatch 2016). In part based on property reforms in the 1988 constitution that treat the "social function" of land, even in urban areas, the Rio's Master Plan created a new legal technology for the urbanization of favela settlements called an Area of Special Social Interest (AEIS in Portuguese) (SMU-RJ 1992; Gonçalves 2013, 297-300). Under the 1988 constitution, informal urban settlements were considered to have legal rights to use the land after five years (Fernandes 1995). According to the former coordinator of Favela-Bairro, the 1992 Plano Diretor established the juridicopolitical framework for extensive interventions in favelas with new legal technologies including resettlement, dispossession, and indemnification in "situations of risk" (Petersen 2004). The Plano Diretor states that in principle, the removal of favelas is not to be considered in light of the mission to "urbanize" favelas, but the clauses that address risk areas and environmental protection provide exceptions to that principle on a case by case basis (Gonçalves 2013, 300). These legal changes provided the political technologies, along with the 100 meter limit for construction passed in 1976, for the state to shift its primary policy for favelas from urban upgrading to risk resettlement after 2010, even though both were called urbanization. ${ }^{30}$

Summarizing the importance of these urban changes, following the 1988 landslides in Rio, urban planners began large scale and intensive efforts to "upgrade"

\footnotetext{
${ }^{30}$ Municipal Decree 322, March 3, 1976.
} 
favelas into the city, while simultaneously establishing legal precedents that allowed for partial or in some cases wholesale favela removals based on the area of risk discourse introduced by the World Bank. The World Bank funded reforestation as a risk mitigation practice, reforestation was a practice with a long history in Rio from the colonial period that would also shape Rio's built environment according to sustainability values. At the same time that it was involved in disaster recovery in Rio, the World Bank played an important role in global biodiversity conservation projects along with major international conservation groups (McNeely et al. 1990). These conservation groups problematized the expansion of human settlements like favelas by framing them as a symptom of the larger imminent crisis of rapidly increasing population growth in the developing world that caused environmental degradation in the form of deforestation.

The new programs and legal technologies that emerged after 1992 in Rio's urban policy emphasized reforestation and controlling the expansion of favela settlements by promoting environmental protection through both reforestation of risk areas and delimitation of protected areas adjacent to favelas. The first urban policy program that attempted to "upgrade" favelas into the city of Rio via extensive infrastructure improvements, Favela-Bairro mapped risk areas in each favela it intervened in to delimit authorized settlement space and define which areas would receive state benefits and Environmentally Protected Areas were automatically excluded. As an effect of the linkage of these issues, a superimposition of risk area and environmental protection discourse was deployed for the control of favelas by Rio's urban policy complex. This superimposition was demonstrated in the creation of "ecolimits", the mapped favela 
borders and material barriers erected after 2001 as part of the Favela-Bairro program, to control favela expansion and delimit favelas from protected areas and risk areas.

\section{Favela urbanization: Ecolimits and territorial control}

In the second phase of Favela-Bairro, initiated in 2001, the ecolimits were a new discursive framing of the border of favelas and green space. In the effort to delimit favelas from previously mapped risk areas and protected areas, the ecolimits were mapped onto favelas and materialized in steel cable borders, fences, and leisure areas planned as buffer zones (Compans and Viñas 2005). While in principle the prohibition of construction in protected areas applied to everyone, in practice the ecolimits were urban control measures specifically applied to favelas that were intended to halt the "horizontal" (read topographical) expansion of favelas into protected areas or environmentally fragile terrain (Compans and Viñas 2005). ${ }^{31}$ The ecolimits were delineated both through and as a result of dislocating residents from risk areas or environmentally protected areas. O Globo, citing a leaked IPP study in 2009, reported that almost seventy percent of the space occupied by human settlement on the protected hillsides of the Tijuca Massif above 100 meters was by middle or upper middle class occupants, which called into the question the social justice of ecolimits applied disproportionately to favelas (Figure 3.5) ${ }^{32}$ After this leak, the discourse of favela

\footnotetext{
${ }^{31}$ This contrasts with "verticalization" of favelas, which refers to adding additional stories to existing structures, a process that accelerated in the 1980s with the transition from wood to brick housing in favelas.

${ }^{32}$ Daflon, Rogério, and Tulio Brandão. 2009. "O Morro Não é Só Dos Pobres.” O Globo, March 22, Rio edition. The IPP study was leaked to O Globo reporters prior to its release and was later never published.
} 
residents responding to area of risk mapping in their communities called in to question why they could see mansions above the legal construction limits while their homes were slated for demolition.

Figure 3.5: Residential settlements on the Tijuca Massif above 100 meters.

Settlements above 100 meter limit

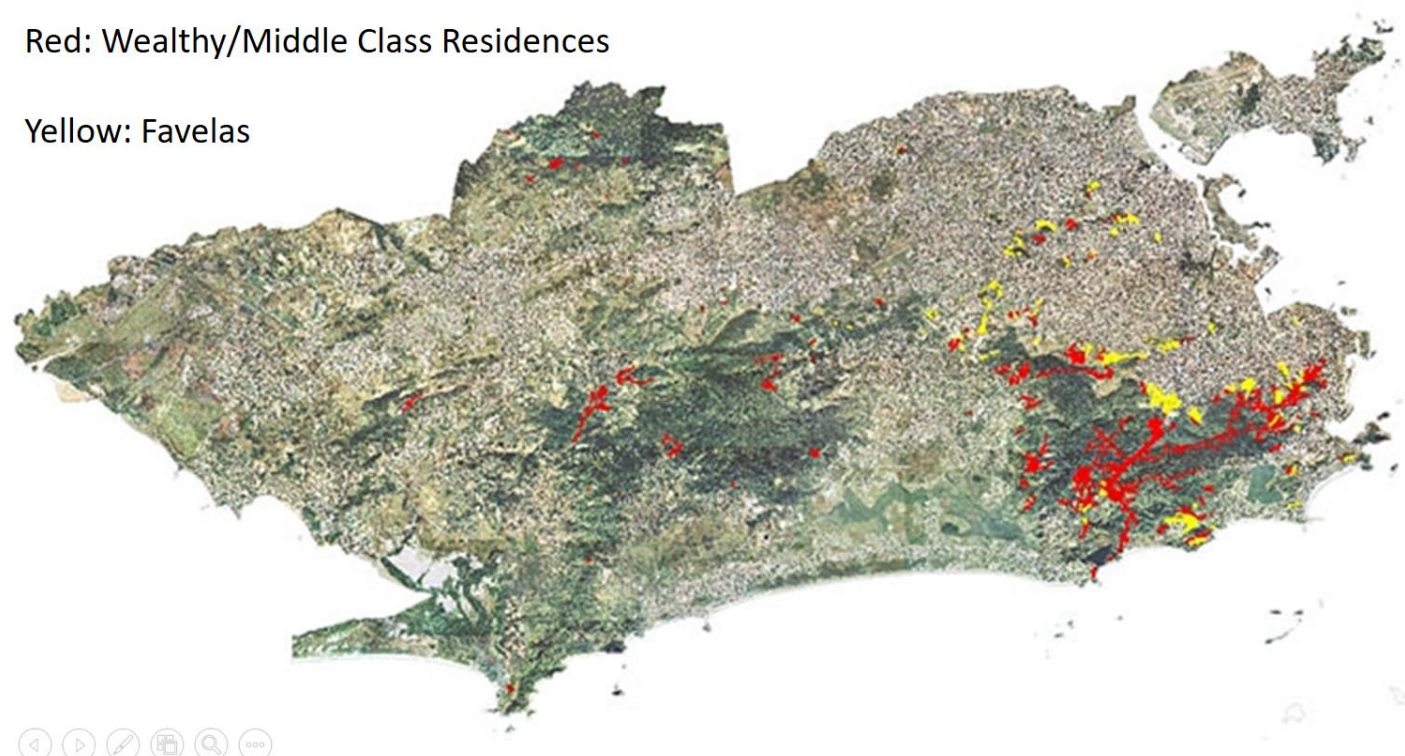

All of the colored areas are above the 100 meter restricted zone for residential settlements, the Cota Cem or One Hundred Quota. Image is attributed to an unpublished IPP study, cited in Daflon, Rogério, and Tulio Brandão. 2009. "O Morro Não é Só Dos Pobres." O Globo, March 22, Rio edition. Image located at the O Globo blogpost below. http://oglobo.globo.com/blogs/blogverde/posts/2009/03/23/ipp-encosta-do-macicoda-tijuca-a-mais-ameacada-171326.asp. Accessed June 11, 2015.

The ecolimits themselves were a response to discourse produced by scholars, figures in government, and media coverage that posed favelas as threats to the forest cover of the Tijuca Massif, which was often combined with the violent image of favelas projected by the media. As part of the urbanization interventions of the 1990s, favelas were reframed as threats to the environment by Rio's urban policy apparatus, construed

Throughout my field research, Santa Marta residents pointed to upper class land use in similar geography to Santa Marta. 
as expansion into protected areas, pollution of waterways and beaches, or offending middle class environmental aesthetics by occupying visible green space (Compans 2007; Fuks 1998). Political pressures were exerted on Rio's administrators by middle class residential associations in rapidly expanding residential areas of Rio. The environmental movement in Rio de Janeiro had gained strength during the dictatorship, playing a role in introducing legislation after 1985 that allowed neighborhood residence associations to take legal action against favela expansions framed as threats to the environment (Fuks 1998). This contributed to the greening of urbanism in Rio, a process that undermined grassroots mobilization on behalf of favelas and strengthened the position of the government in the urban policy complex (Compans 2007). Compans argues that the greening of the urban policy complex depoliticized favela resident's claims to the right of possession, and that this was an effect of the newly greened discourses of favela control super imposed upon the recycled discourses of hygiene, morality, and crime in urban policy. The environmental arguments of Rio's residence associations had succeeded in making environmental protection a powerful discourse in favela policy, when combined with risk area-as-disaster-management, it provided a potent and difficult to refute argument for the government to use in the coming return of favela removals to Rio. By the mid-2000s, favelas were reconfigured in urban and conservation policy as threats to the environment, the sustainability of the Tijuca Massif, sources of crime in national parks, and as landslide risk areas by discourses of public safety, sustainability, and environmental aesthetics (Netto 2005; Peixoto et al. 2007).

As I have written here, the legal framework enacted to implement Favela-Bairro after the adoption of the 1988 Constitution produced a reconfiguration of the urban policy 
complex that was programmed to transform favelas by upgrading them, in contrast to the 1960s and 1970s policy of favela eradication via displacement or removals. This legal framework proscribed conditions under which favelas could be expropriated or resettled as part of the urbanization process. Risk mapping was the governmental technology that framed the legality of these expropriations, enabled by legislation designed to urbanize favelas. Risk area discourse recast many favelas in a state of exception, similar to the 1937 Building Code, where their right to the land was put in question in a way that the urban policy apparatus could displace them without legal recourse for the residents. Said another way, wherever risk was mapped by government recognized specialists, favela residents' rights to land use was infringed. At the same time that risk mapping was being used to control favela expansion through the Favela Bairro program, drug violence increased and provided another justification of urban public policy to focus on favelas.

Political pressure to control favela expansion reached a high point in the mid2000s after a high profile episode of violence in the favela Rocinha, located near Barra, a more suburban type neighborhood to the southwest of the Tijuca massif, where the 2016 Olympics would be held. Rocinha's proximity to Barra's residential development and the TNP, combined with escalating drug violence, resulted in Rocinha appearing in an overwhelming share of media coverage of Rio's favelas during the 2000s (Coelho 2008). An outbreak of drug violence in 2004 in Rocinha and Vidigal overshadowed the different urban interventions by the prefecture and put pressure on the Rio state government to move beyond control via urbanism of favelas. The shootouts of 2004 were followed by a series of editorial articles in O Globo that argued that stronger measures were called for to control drug violence, with both walls for favelas and favela removals proposed in the 
newspapers. A series of Globo Articles titled "It is illegal, what now?" problematized the favela expansion in 2004 after the new favela programs had failed to control favela expansion in Rocinha (Compans 2007). The Rio state government proposed to wall off Rocinha and three other favelas near the Rio suburb of Barra after a particularly egregious episode of drug violence within the favela Rocinha that interrupted the daily lives of Rio residents living, travelling through, and working in Barra (Coelho 2008). This proposal generated an intense public controversy and debate about social segregation, with comparisons to apartheid in South Africa. To justify the walling off of these favelas, three potential benefits were given by the state government for the wall (Coelho 2008):

1. Protection of the rainforest.

2. Containment of favela expansion.

3. Public safety.

This triangle of discourses would continue past this event and reemerge in risk area discourse after 2008.

Human rights advocates and critics of the administration argued that the walls would be ineffective against drug trafficking and favela expansion, and even worse they had the appearance of an apartheid policy for favelas. The wall proposal by the administration showed that favela removals as state policy were not considered viable by Rio's urban policy apparatus in the mid-2000s. The state policy of favela removals from the dictatorship era was considered by many scholars to have been abandoned beginning in the early 1980s (Cavalcanti 2007; Perlman 2010; Valladares 2005). When the 
democratic transition began in Rio de Janeiro in the late 1970s, urbanization-asupgrading was the only favela policy that Rio's politicians could support and be elected (Gay 1994). By the mid-1980s, the removal threat had been subsumed by fear of drug trafficking (Perlman 2010, 169). In the 1990s, as cocaine trafficking and use increased in Rio de Janeiro, a widespread increase in media coverage and scholarship associated favelas with violence and drug trafficking (Cavalcanti 2007). Valladares argues that the media representations of favelas, as sources and objects of violence, reignited scholar interest in favelas in the 1990s, after mass favela removals ceased to be politically feasible in the early 1980s (Valladares 2008). The print and television media increasingly associated favelas with drug violence by calling favelas “areas of risk" during the 2000's, a phrase census takers for the Brazilian Institute of Geography and Economics even used in 2010 when explaining why it was necessary for favela residents to carry out the census themselves using computers or cell phones (Perlman 2010, 194; O Globo 2011). The favela Santa Marta was among the favelas most studied through the lens of violence through 2002 (Valladares 2008).

\section{Conclusion}

This chapter lays out four major moments in the history of favelas. First, I recounted the history of favela removals and displacements before the end of the military dictatorship in the early 1980s. These removals were entangled with the discourses of hygiene, communism and urbanization that had framed favelas before the 1960s. Second, I examined how favelas were framed as threats to Rio's forest cover and sustainability beginning in the 1970s. Thirdly, I trace the emergence of the "risk area" political technology in Rio to the disaster response intervention following the 1988 torrential 
rainfalls and landslides that followed. Fourthly, I show that the new favela interventions are entangled with the discourses of favelas as threats to forest cover, as "areas of risk" that are a threat to favela residents themselves, and as sites of drug trafficking violence.

My analysis in this chapter of the discursive framing of favelas using "risk area" shows that after the IADB disaster intervention in the late 1980s, favelas were the objects of two different discursive moves during the 1990s. The first was "risk area" related to the return of urbanization interventions and disaster management in the early 1990s, the second was "risk area" related to media accounts of drug trafficking and violence beginning in the late 1990s. The violent framing of favelas hit a crescendo in the mid2000s, and a new phase of urbanization interventions began in 2009, when risk area-asdisaster-management discourse came to prominence. Along with reframing of favelas as areas of potential disasters, favela removals as a state policy returned to Rio de Janeiro in 2009, which according to the architect Faulhaber has surpassed all previous periods of favela removals by the prefecture (Faulhaber and Azevedo 2016). After a series of urbanization interventions in the 2000s, Santa Marta was remapped for risk in 2010, following the installation of the UPP and the landslides of 2010. In 2012, while I was doing my field research, urbanization returned to Santa Marta with the new emphasis on DRR. The high profile of Santa Marta, among other reasons such as proximity to the center of Rio, previous urbanization infrastucture, and its built geography, led to Santa Marta to be labeled the "model favela" after the first UPP unit was implemented there. Residents were quick to critique Santa Marta's use to promote government programs, pointing to insufficient state services and infrastructure in different parts of the favela. I return to these themes in chapters four and five. 


\section{Chapter IV: Ecolimits, Resilience Biopolitics, and Resettlement in Santa Marta}

Here I analyze the events after 2000 in Rio de Janeiro and Santa Marta to show how risk mapping for favelas emerged in ways that produced a new biopolitical technology of government for managing and controlling favelas, but also how it produced a new politics of place that pushed back against the displacement and resettlement of favela residents. In the first section I review the events and legal changes important for understanding the efforts to control Santa Marta's area of settlement beginning with the wall constructed around Santa Marta in 2009, ostensibly to prevent home construction inside EPAs. I then go back temporally and review the narrative of favela expansion from 2004-2009 and the controversy over the relationship between favela expansion and the reduction of forest cover in Rio. I then examine the emergence of the legal technologies for upgrading favelas and delimiting their boundaries with EPAs. In the second section I examine the entanglement of the area of risk political technology with urbanization interventions in Santa Marta through the lens of what I call "resilience biopolitics". In the third section I write on the general assembly event where residents learned about the resettlement plan and the reforestation of the Peak. In the fourth section, I review the urbanization experiences of Santa Marta in the mid-2000s, their efforts to organize and prepare for the general assembly in 2012, and their responses to the state's presentation in the general assembly. 
The controversies over favela expansion: ecobarriers and ecolimits

The construction of a wall around Santa Marta in April of 2009, labeled an "ecobarrier" by the state, proved to be the first measure that would become internationally controversial in the year after the UPP was installed in Santa Marta in November of 2008 (Phillips 2009). The wall was constructed on the only border of Santa Marta not closed off by the built environment or its physical geography. The wall was asserted by the government as necessary to both prevent the expansion of Santa Marta and also to protect the surrounding rainforest that was codified and mapped as an EPA by the state of Rio (Phillips 2009). Ícaro Moreno, head of EMOP, Rio state's civil construction firm, adamantly asserted that the three meter wall was necessary to prevent the expansion of Santa Marta into the surrounding forest (Moreno 2009; Regalado 2009). The state of Rio announced in 2009 that the UPP project would be expanded to several other favelas and that the walls would also be built in 12 other favelas. The activist Mauricio Campos, member of the Rede Contra Violencia (Network Against Violence), compared the walls to apartheid in Africa and the Palestinian territories in an interview with the Guardian where he argued that social segregation would be the end result of the wall project (Phillips 2009). José Saramongo, the nobel laureate author, used his celebrity to echo Campos' criticism of the wall as a form of apartheid and this was widely circulated in various international news outlets (Velasquez-Manoff 2009). Justiça Global (Global Justice), the Rio de Janeiro NGO, brought the issue of the walls to the attention of the United Nations and also worked with other human rights organizations in Rio to 
issue a statement on the treatment of favelas in 2009 that called the walls "socio-limits" (Global Justice 2009). The UN punctuated this criticism, referring to the walls as "geographical discrimination" and questioned the protection of human rights in Brazil (Chade 2009). Subsequently, the ecobarrier program was abandoned after constructing walls in only 4 of 12 favelas planned in the first phase (Camargo 2012).

Although he did not oppose the construction of the wall, the president of Santa Marta's resident association asked that the wall be limited to a meter in height or that walkways be opened up at intervals in the wall, but both requests were rebuffed by the state of Rio. Residents that were still coming to terms with the UPP occupation questioned the purpose of the wall and asserted that the one million reals was better used to make infrastructure improvements in Santa Marta. ${ }^{33} \mathrm{O}$ Globo, the dominant news organization in Rio, published numerous articles that linked the eco-barrier in Santa Marta with environmental protection and favela expansion. Not long after, the construction of the eco-barrier in Santa Marta generated substantial criticism both within and without Rio. ${ }^{34}$ Itamar Silva, a resident activist in Santa Marta and journalist, argued that walls inherently separate society and create ghettos, going against the struggle to recognize favelas as part of the city (Araujo and Miliotti 2009; Nogueira and Zahar 2009). Rio's activists raised the alarm after the announcement of the expansion of the wall project to other favelas like Babilonia Chapeu-Mangueira (Babilonia) and Rocinha

\footnotetext{
${ }^{33}$ About $\$ 500,000$ US at that time. Resident comments from fieldnotes at various times.

${ }^{34}$ See the series of editorials debating the ecobarrier project in Sao Paulo's main newspaper the Folha de Sao Paulo on April 13 ${ }^{\text {th }} 2009$ (Moreno 2009; Magalhães 2009; Folha de Sao Paulo 2009).
} 
in the rich southern zone of Rio. Activists in Babilonia, alarmed by the release of the plan and the rapid construction of the wall in Santa Marta, quickly determined that they would protest and contest the wall construction. ${ }^{35}$ They organized a group of favela residents that brought their protests directly to the governor's office in Rio. They were successful in preventing the wall from being constructed and instead replaced with a foot pathway. The residents' association in Rocinha voted against the wall, but later allowed the wall as a condition for urbanization improvements in Rocinha.

After the wall was built in Santa Marta, researchers called attention to a fatal flaw in the state's argument that the wall was necessary to keep Santa Marta from expanding. The prefecture's own aerial photos from the IPP showed that the settlement of Santa Marta had been shrinking in total area since 1999 and that favela expansion in the southern zone of Rio, where many of the walls were scheduled to be built, was very low (Lemos 2011; Alvaro Ferreira 2009; Vial and Cavallieri 2009). Santa Marta's non-growth contradicted the narrative that Rio's favelas were expanding, which was rooted in studies using satellite imaging analysis released in 2004, 2007, and 2009 that presented alarming expansion rates for favelas, primarily in western Rio de Janeiro (Schmidt and Marquero 2004; BBC Brasil 2007; Soares 2009). In October of 2007, the governor of Rio de Janeiro linked population growth in favelas to crime while affirming his support for the legalization of abortion, stating that favelas were "factories for producing criminals" and that the fertility rate in the favelas were "like Zambia" while the rest of the city was at "Swiss levels" (Freire 2007). The combination of census data and satellite imagery

\footnotetext{
${ }^{35}$ Author's interview with an activist from Babilonia on February 22, 2012.
} 
increased the legibility of favelas for governmental actors in Rio and changes and correlations found in the data were then used to problematize the expansion of favelas.

The expansion of the favelas "horizontally" meant that favelas were expanding past the borders designated for urbanization, called ecolimites (ecolimits) (Vial and Cavallieri 2009). The construction of the eco-barrier in Santa Marta served as a message from Rio's government that it was taking steps to control favela expansion into forested areas, and that the government was asserting control over Rio's favelas (Soares 2009). Other studies tied favela expansion to decreases in forest cover, such as a study of deforestation in Brazil that found that the Atlantic Rainforest of Rio was disappearing at an increased rate over the period 2005-2008, compared to the previous study for the period 2000-2004 (INPE 2008). The study was the product of a collaboration between an NGO called SOS Mata Atlântica (SOS Atlantic Rainforest) and the Brazilian version of NASA (INPE), which provides satellite imagery for the annual reports. When combined with the first satellite study that estimated favela expansion, released in 2007 , the conclusions linked the deforestation in the Rio area to the expansion of favelas, measured in comparison to the size of Santa Marta, based on examination and interpretation of anthropogenic change from the satellite imagery (BBC Brasil 2007). ${ }^{36}$ Furthermore, the satellite photo based study found that Santa Marta increased in size by misidentifying road access and other open areas that existed in 1999 as new settlement (Schmidt 2007; Lemos 2011; Alvaro Ferreira 2009). This demonstrates the making legible aspect of the

\footnotetext{
${ }^{36}$ Satellite images are linked in this article and the FIRJAN study uses Santa Marta as a size reference for the area of favela expansion. Changes in the resolution of the imagery were preconditions for making out changes in favela settlements.
} 
rendering technical process, which made it possible for the government and environmentalists to assert a general causal relationship between favela expansion and the reduction of forest cover. Here the process of rendering technical is a strong example of disciplinary power, as the calculation of changes in areas covered by favelas delimitation involves both making favelas legible and also sets the stage for their continued surveillance. Whereas earlier the state was attempting to control favela expansion into protected areas with the materialized ecolimits, from 2008 on it did so with satellite imagery (Vial and Cavallieri 2009).

Ecolimits, or the border between favelas and EPAs, were mapped in 2000 with the promulgation of Area de Especial Interesse Social or AEIS (Area of Special Social Interest), which designated specific favelas for urban upgrading. Prior to the circulation of the 2007 FIRJAN study, the ecolimits had been marked off by steel cables and foot pathways in favelas like Rocinha and Rio das Pedras. These limits were not physically policed in favelas like Rocinha, and home construction expanded beyond the materialized boundaries. The ecolimits had been mapped onto parts of favelas that had long preexisted the laws that later established the ecolimits, including the Lei Organica and the Plano Diretor (Compans 2007). However, no material ecolimits had been constructed in Santa Marta because the water drainage system installed to reduce the risk of landslides in the early 1990s acted as an effective demarcation of settlement in Santa Marta. ${ }^{37}$ In 2004, mayor Conde used arguments for the construction of a wall that collapsed public security into environmental protection, but human rights advocates mobilized enough

\footnotetext{
${ }^{37}$ Interview with the president of the residents' association in Sept of 2012.
} 
resistance that the wall policy for favelas was shelved until it re-emerged in 2009 (Carro 2004; BBC News 2004). The ecobarriers were proposed earlier by Rio's mayor Eduardo Paes (2012-2016) while he worked as a regional official in the rapidly urbanizing western zone of Rio (1993-1996), but the ecolimits first materialized as part of favela urbanization in the Favela-Bairro project (Zahar 2009; Cardoso and Araujo 2007). While Santa Marta was not included in Favela-Bairro in the 1990s, it was made an AEIS in 2000 and was designated for urban upgrades in the 2000s (see Figure 4.1).

Figure 4.1: Area of Special Social Interest map of Santa Marta

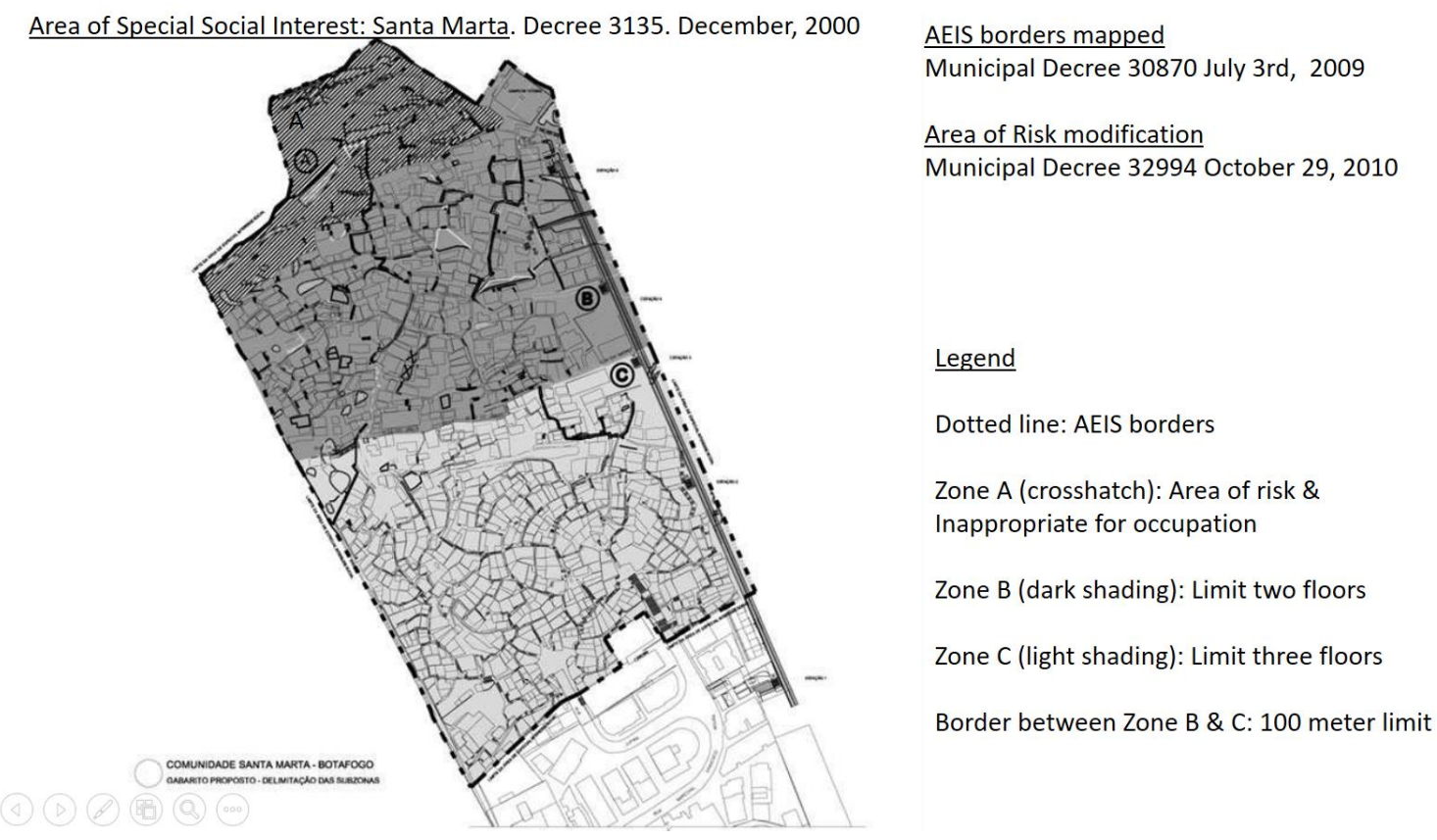

The Santa Marta AEIS was created in 2000, the AEIS borders were mapped in 2009, and the crosshatched area at the top (The Peak) was remapped as a high risk area in 2010. The floor limits are zoning codes for the number of floors allowed in each building. The 100 Meter Limit is the border defining Zone B from Zone C. Figure adapted from the 2010 prefecture of Rio summary document of AEIS decrees in Santa Marta.

After the UPP implantation in Santa Marta, a whole series of spatial management techniques would become feasible, aside from the previously detailed surveillance, streets would become named and houses numbered. In 2009 the favela was mapped in detail 
that showed every home, walkway, and alley in the update to the 2000 municipal decree that defined Santa Marta as an AEIS (see Figure 4.1 above). The 2009 AEIS update in Santa Marta was the product of multi-scalar governmental cooperation as the urbanization of favelas required municipal, state, and federal levels of governmental activity, in the form of municipal decrees according to federal laws and with the allocation of state and federal resources. This multiscalar governmental effort, based on municipal decrees, state and federal resources, and the Cities Statute produced the sociolegal conditions for intervention in Santa Marta.

In the following section I will discuss how Santa Marta has been reconfigured by disciplinary power and how this has enabled the current series of interventions in Santa Marta before moving on to discuss in greater depth how Santa Marta has been problematized and rendered technical for those interventions by the state. While the AEIS was specifically designed for legalizing and urbanizing favela occupations in Rio, the area of risk technology of governance is a code for delimiting urban development throughout Brazil.

\section{Resilience biopolitics and the Morar Seguro resettlement plan}

Santa Marta's AEIS coded which areas were authorized for urbanization. Immediately after the implantation of the UPP, home construction was prohibited throughout the favela and monitored by special urban zoning office for favelas called a Posto de Orientação Urbanística e Social or POUSO (Urban and Social Orientation Office). This office barred new construction for the first year after the UPP was installed, and then introduced new restrictions on the number of floors for each home depending on 
its altitude and the quality of its construction. Santa Marta, a steep hill with nearly 800 steps, was demarcated by the stations for the plano inclinado (funicular tram), affectionately known as the "bondinho"(tram or cable car). There are five stations and each station has become a point of reference for one's location in the favela. The third station roughly marks the 100 meter quota, the upper limit for legal urbanization throughout Rio, a limit commonly transgressed by both mansions and favelas. The fourth and fifth stations mark the upper reaches of the favela known as the o Pico (The Peak). In between the fourth and fifth station lies the demarcation in the AEIS of where the zone “impropriate for occupation" begins. This zone was delimited based on governmental calculation underpinned by truth regimes formed from geological and climate risk sciences. Calculating geological risk is undertaken by assessing geological characteristics of the landscape, including hydrology, soil type, inclination, and forest cover. Geogological risk was represented to favela residents by color shading topographic maps into low, medium, and high risk. It is a disciplinary knowledge formulated to delimit and police human habitation, absent some form of technological mediation of risk. In Santa Marta, it is a contested boundary that sets the stage for the reassertion of politics, in other words, destabilizing the process of rendering technical. Before turning to that struggle, I will show how the area of risk technology of governance is a part of a new form biopolitics for managing favelas in Rio de Janeiro.

Biopower, as one of the analytics that can constitute governmentality, conceptualizes the calculation and rendering technical of problematics that are understood to inhibit human life like disease, risk, and violence. Area of risk governance seeks to simultaneously prevent the loss of life from catastrophes that result from human 
production of the built environment and to protect and conserve socially produced green spaces like forests. ${ }^{38}$ It is a discourse of both human preservation and forest conservation in order to reduce disaster risk, which I call "resilience biopolitics". Residents of Santa Marta first encountered this framing of area of risk discourse after the implantation of the UPP with the disclosure of the new AEIS municipal decree in 2009. This decree was put into practice by the agents of the POUSO in Santa Marta, whose office was implanted after the UPP. Agents of the POUSO traversed the Santa Marta to establish the limits of construction, using photography and interviews to identify new constructions. ${ }^{39}$ After a period of approximately a year, residents became accustomed to the new control regime and even denounced their neighbors' new constructions by calling the POUSO agents. Other residents ignored the control measures and proceeded with construction, sometimes concealing or contesting POUSO records. The POUSO agents also informed those residing within the mapped high risk area that new construction was not allowed and that their access to municipal water and electricity was illegal. When new construction was allowed in 2010, residents of the peak were excluded from the relaxing of the prohibition on new construction. The problematization of area of risk and favelas reached new scalar proportions after the 2010 landslide catastrophes throughout the state of Rio de Janeiro followed severe rainfall, but Santa Marta avoided tragedy during that series of disasters (MMA-SBF Brazil 2011).

\footnotetext{
${ }^{38}$ Brazil's federal Ministry of the Environment issued a document that analyzed the landslides of 2010 in Rio de Janeiro state and explicitly linked conservation with risk prevention on hillsides and near water sources (MMA-SBF Brazil 2011).

${ }^{39}$ Interview with a POUSO employee on August 17, 2012.
} 
Residents of Santa Marta were cognizant of the implications of the statewide area of risk emergency. Itamar Silva, resident activist and former president of Santa Marta's resident association, delivered a statement on resident concerns about area of risk resettlements to President Lula during his 2010 visit to inaugurate the new tourist program for favelas launched in Santa Marta (see Appendix). In that statement, Silva called attention to the historic importance of the peak of Santa Marta, which was the site of the original settlement in the early 1900s, arguing for the urbanization of the peak in a way that avoided resettlement and included resident concerns, in light of Santa Marta's branding as the model favela. The new urbanization plan for Santa Marta called for the construction of government housing below the peak and along the eco-barrier in order to remove the residents of the peak. The specifics of this plan were divulged to residents during a meeting called by the residents' association in November of 2011, attended by the vice governor of Rio and Rio's head architect. Residents were allowed to voice their concerns in an unstructured manner that revealed strong feelings of neglect for years of social exclusion in the favela. Several residents of the peak were allowed to speak and criticize the new plans as arbitrary and lacking resident perspectives on intervention planning as well as ignoring previous stalled interventions to urbanize Santa Marta that included the peak, especially the canal system to alter its hydrology. This disconnect between intervention events was also present in the plan to prepare Santa Marta's residents for resettlement, which was conducted by an engineering firm called Urbaniza contracted as a public private organization to construct a socioeconomic profile of affected residents and register them for federal social programs before resettlement. Urbaniza scheduled a series of meetings to address residents' concerns and inform 
residents about the resettlement process. To understand why the state was resettling the Peak residents in 2012, I return here to the events that preceded the resettlement meetings and the general assembly on urbanization in Santa Marta in January of 2012.

Following the torrential rains and the resulting landslides in several cities surrounding the Rio de Janeiro (Rio) municipal area in 2010 and 2011, the state of Rio launched a massive favela removal and resettlement campaign to reduce the number and size of favelas in "high risk areas". The first of series of removals in places like Favela do Metro and Tabajaras were rapid and forceful. ${ }^{40}$ The state made no effort to resettle these residents after it destroyed their homes, small payments and rent subsidies were given out. As the risk area campaign continued, it magnified the removals already in process for favelas in the way of World Cup and Olympic construction (Faulhaber and Azevedo 2016). Brazil was awarded the 2016 Olympics in 2008, which was promoted to the Olympics committee by promising to also launch a new community policing program for favelas, later rebranded the Unidade de Policia Pacificadora, or Pacification Police Unit (UPP). The UPP was first implemented in the favela Santa Marta, later nicknamed "the model favela" by administrators and public relations employees of the state. The upper portion of Santa Marta, known as the Peak, had been reclassified as a high risk area in 2009, and the state of Rio informed residents of Santa Marta in late 2011 that a resettlement program was in preparation for the Peak.

\footnotetext{
${ }^{40}$ Tabajaras is located on the other side of the Botafogo neighborhood from my research site, within the view of the upper half of Santa Marta.
} 
In the rest of this section, I examine the 2010 resettlement program called Morar Seguro (Living Safely) using the biopolitics analytic and assemblage framework from chapter two. Following two major landslide events in early 2010, Morar Seguro was promulgated by the governor of Rio de Janeiro state in April, 2010. Two small cities nearby were devastated and one favela in Niteroi, a city across the bay from Rio was the site of a terrible tragedy where hundreds of favela residents died under a mudslide. Following these events, the governor of Rio declared a state of emergency and promulgated a program, Morar Seguro, to resettle residents of Rio de Janeiro state that lived in areas that were mapped as high risk. This program called for risk mapping statewide, the construction of government project housing, and the resettlement of residents mapped in high risk areas. The wording of the law that launched the program stated that it was a housing construction program to resettle residents living in areas of risk. The program to resettle residents that were mapped in high risk areas had three major projects (Cabral 2010). First, the program called for risk mapping of a majority of urban areas into low, medium, and high risk zones. In cases like the Rio metro area, the prefectures could carry out the risk mapping if they had the appropriate technical staff, otherwise the state of Rio would carry out the risk mapping. Second, residents of high risk areas were to be removed and either resettled to new housing, given subsidized rent in a new location, or compensated for their building materials. Third, the state constructed new housing projects for the newly evicted residents from high risk areas and those recently displaced by disasters. In 2011, the Morar Seguro program gained nearly half a billion dollars in financing from the World Bank (World Bank 2011). Initially created with state funds, the World Bank stipulated that the state of Rio provide teams of 
people to attend to the "social" which meant to provide participatory forums for residents to ask questions about the resettlement project, to provide input about the construction of the buildings, and to increase the income of affected residents via welfare and job programs. In the case of Santa Marta, the state of Rio contracted Urbaniza, which had already carried out a similar project in another Rio favela. The mapping of risk was carried out by GeoRio, a municipal geology and civil engineering firm that assessed and mitigated risk in the Rio metro area.

I am examining the risk resettlement project for Santa Marta that has been folded into the Morar Seguro program through Foucault's version of biopolitics. The risk mapping and resettlement project in Rio exhibits characteristics of both "making live" and letting die, while simultaneously producing protected areas for reforestation and conservation (Michel Foucault et al. 2003, 241). Risk mapping was a calculative practice that was predicated on the "making live" aspect of biopolitics and had the effect of displacing favela residents from areas that the state had deemed "high risk". The "letting die" aspect of biopolitics was put into practice by creating geographies of uneven service provision through which the state denied the expansion of infrastructure for self-built housing, exposing those residents to greater risks of both health and disaster risks (Braun 2014, 56). As Bakker writes on the biopolitics of urban water, the uneven provision of infrastructure has a direct effect on the health of communities, including access to clean water, sewage removal, and in the case of Santa Marta it mitigates the risk of landslides by redirecting water drainage (Bakker 2013, 282). Furthermore, the resettlement process included making residents of favelas legible to the state by carrying out socioeconomic surveys and registering residents for social programs. The government project housing, 
constructed nearby lower on the hill, has disciplining effects for residents that are resettled. These effects include new costs of living, social relations, and enhanced legibility by relocating residents into government project housing with fixed tenure and addresses.

In the Rio metro area, Morar Seguro as a risk resettlement program had the effect of displacing favela residents from the south and north zones of Rio to the distant west zone of Rio (Faulhaber and Azevedo 2016). This happened for two reasons. First, favela residents are among the most socioeconomically vulnerable residents of Rio and as such cannot purchase property in the high cost of living Rio metro area, so the tendency after displacement is to settle on peripheral land in poor locations. Second, the government of Rio has allowed wealthier residents to construct homes in risk areas as long as those residents pay for risk mitigation recommended by the state's technicians (Daflon and Brandão 2009). ${ }^{41}$ Wealthier residents were allowed to alter their risk status by selffinancing risk mitigation infrastructure, with the effect that favelas were the primary form of settlements targeted by the Morar Seguro program.

The power relations produced by the Morar Seguro program, and the assemblage of urbanization projects in Santa Marta that preceded it, can be examined using biopolitics in ways that recognize that while new ways of governing life have emerged, state power is often exercised in ways that exploit pre-existing forms of control, namely sovereign and disciplinary power. While the intervention in Santa Marta is primarily biopolitical, laws and decrees from the state play key roles in problematizing high risk

\footnotetext{
${ }^{41}$ Participant observation from the July 2012 GeoRio meeting in the UPP headquarters.
} 
areas, even preceded by the use of brute coercion to evict residents from favelas in the city center. Eviction, or displacement for the production of conservation areas, is a form of seizure and a practice of sovereign power, and it is also a practice that tends to produce a strong political reaction among those evicted. Santa Marta residents witnessed that the prefecture had summarily evicted favela residents in nearby Tabajaras, but in Santa Marta the state was using risk mapping and arguments of moral obligation to conduct resident choices. The resettlement program in Santa Marta was initiated with the threat of seizure looming in the minds of favela residents, even as the agents of the state seek to convince residents that resettlement is in their best interest. For the resettlement project in Santa Marta, the process of what Tania Li calls "forging alignments" between the state and residents was performed by a trustee called Urbaniza, mentioned earlier in the chapter ( $\mathrm{Li}$ $2007 \mathrm{~b}, 265)$. Forging alignments is the practice of linking the improvement of the governed and government in assemblages. Next I will relate how that process unfolded in Santa Marta during my field research, focusing specifically on the activities of Urbaniza in Santa Marta.

Urbaniza was contracted by the state of Rio de Janeiro, since the upper half of Santa Marta is administered by the state and the lower half by the municipality of Rio, to carry out the "social side" of the resettlement project for the uppermost portion of Santa Marta, known as the Peak. ${ }^{42}$ This "social side" was a requirement stipulated by the loan agreement with the World Bank, which included participatory practices to present

\footnotetext{
${ }^{42}$ My fieldwork carried out from January to December of 2012 followed the activities of Urbaniza in Santa Marta as they held public meetings with residents about the resettlement project, examined their homes, and surveyed them for socioeconomic vulnerability.
} 
residents with their options under the resettlement program. These options were predefined as resettlement to the project housing, compensation for the value of the building materials of their home, or subsidized rent in another location. Compensation for building materials was severely insufficient to secure housing near Santa Marta, and the subsidized rent was a poor substitute for owning one's home in one of the better areas of Rio de Janeiro. This particular technique of government is a tactic of anti-politics, which $\mathrm{Li}$ writes is a practice of "encouraging citizens to engage in debate while limiting the agenda (Li 2007b, 265).” Residents of Santa Marta critiqued this anti-political practice of government in several meetings, which I examine in this chapter and in chapter five. While the calculation of socioeconomic vulnerability was carried out by Urbaniza, the calculation of landslide risk was carried out by GeoRio (see chapter five). When residents refused to recognize the assessment of the Peak as a high risk area and disputed that assessment with their own situated knowledge, Urbaniza brought a specialist from GeoRio as an agent of authorizing knowledge regarding the risk mapping in Santa Marta, which is another aspect of anti-politics. Thus, I argue the Urbaniza is exercising a "will to improve" and is articulated in an assemblage with GeoRio and the residents of the Peak, using practices of government that correspond with anti-politics and rendering technical concepts from the analytics of assemblage. Following $\mathrm{Li}$, I show that these practices are incomplete and contested by resident politics even within participatory practices initiated by Urbaniza as a trustee.

Resident participation in the assemblage of favela resettlement is predicated on the discourse of urbanization which promises improvement for Rio's favelas. The residents of Santa Marta were promised complete urbanization projects that would 
provide access to water, sewage systems, and the transportation network. What they received in the previous three decades was an incomplete attempt to fulfill that promise and later a resettlement project that contradicted the promise of urbanization, which residents understood as onsite improvement. This sort of disconnect is what Li calls the "convergence and fracture" of the will to improve, where the objects of improvement have different understandings of what improvement will look like after promises of improvement induced their participation in the program (Li 2007b, 268). The resettlement project I researched conflicted with resident's understanding of their rights to living space, accrued by living in the same home for decades, criteria strengthened by the 1988 constitution (Caldeira and Holston 2005). The discourse of DRR, specifically for landslides, has permeated the urbanization project in Santa Marta and the hillside favelas of Rio more generally, and convergence and fracture are effects.

Figure 4.2: Flyer for the "Roots of the Santa: SOS from the Peak" event.

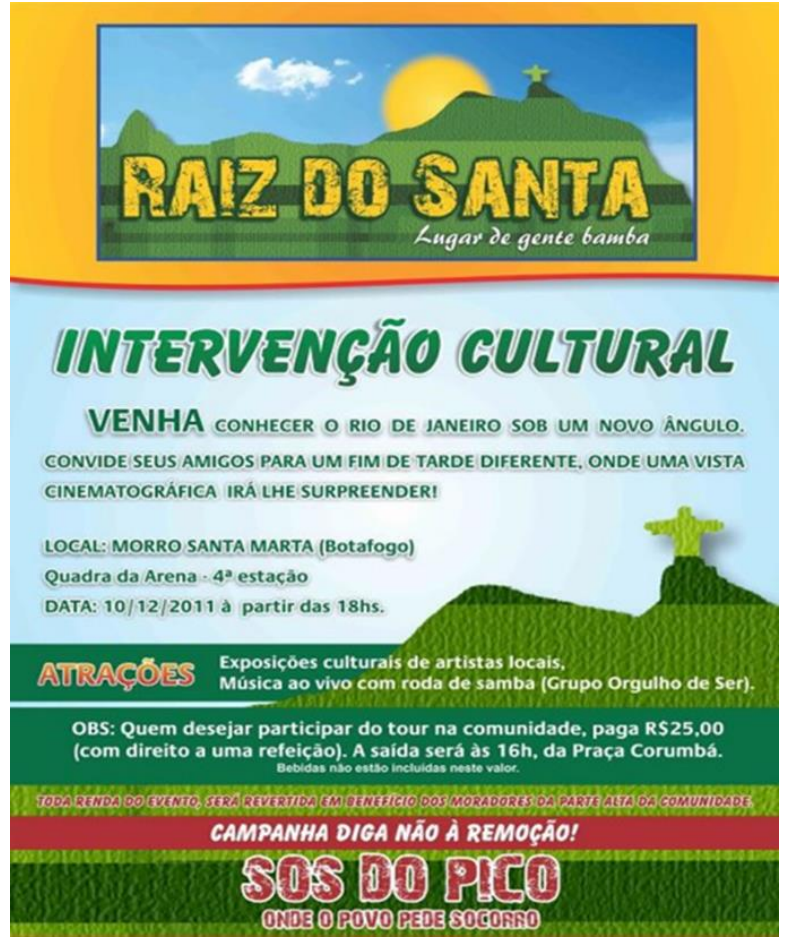

This promotional flyer for the Raiz do Santa: SOS do Pico (SOS from the Peak) event held on December 10, 2011 references the Peak as the origin of the favela and frames the event as a "cultural intervention" against the removal of the Peak, but also as a call "where the people ask for help". The samba group "Orgulho de Ser" (Proud to Be) was scheduled to play. It was also a benefit event to fund Peak Committee activities. Peak residents sold food, refreshments, and tshirts. Prior to the event paid tours of Santa Marta were offered. 
I first encountered the residents threatened by resettlement in Santa Marta on December of 2011 at a community meeting called "SOS from the Peak", which was called to raise consciousness of the state's plan to resettle the Peak residents (See Figure 4.2). ${ }^{43}$ At this meeting, I heard residents express both their attachment to the Peak and the difficulties of living on the Peak of Santa Marta. Participants related the history of how activists from the Catholic Church collaborated with residents of Santa Marta to bring running water to the Peak. Prior to the construction of the bondinho (resident vernacular for the furnicular tram) in 2008, residents of the uppermost section of Santa Marta had to climb nearly 800 stairs each day to reach their homes, often carrying groceries or work items. Participants recounted previous promises to "urbanize", or improve living conditions of the Peak. In 2009, the state's AEIS for Santa Marta was remapped to classify the Peak as a "high risk zone", following a municipal decree issued by the mayor's office (Figure 4.1). The high risk classification meant that all new construction was frozen and even repairs required the approval of municipal zoning agents. The decree was posted outside the residents association where residents picked up their mail. ${ }^{44}$ The state would not advise all of Santa Marta's residents of where and how they would be resettled until January of 2012. This announcement, in a general assembly meeting in the Quadra (Community Hall) at the bottom of the favela, began a new level of insecurity for residents of the Peak, that of the imminent threat of displacement.

\footnotetext{
${ }^{43}$ I was made aware of this meeting a team of Brazilian qualitative researchers from the Fundação Getúlio Vargas after I had accompanied them on their interviews for a research project on discrimination and citizenship in favelas, with a focus on Santa Marta.

${ }^{44}$ Fieldnotes from April 15 ${ }^{\text {th }}, 2012$.
} 
The return of urbanization and resettlement in Santa Marta

Figure 4.3: Urbanization plan showing the reforestation of the Peak.

Phase II

1. Urbanization of Access Streets

2. 64 Habitation Units

3. Community Center for Social Activities

Phase III

1. 128 Habitation Units

2. Center for Sports Training

3. 2 Leisure Areas

4. Reforestation on the Areas of Risk

Translated by author from legend. Fieldwork occurred during Phase II. Construction was not finished on the first building as of September 2016.

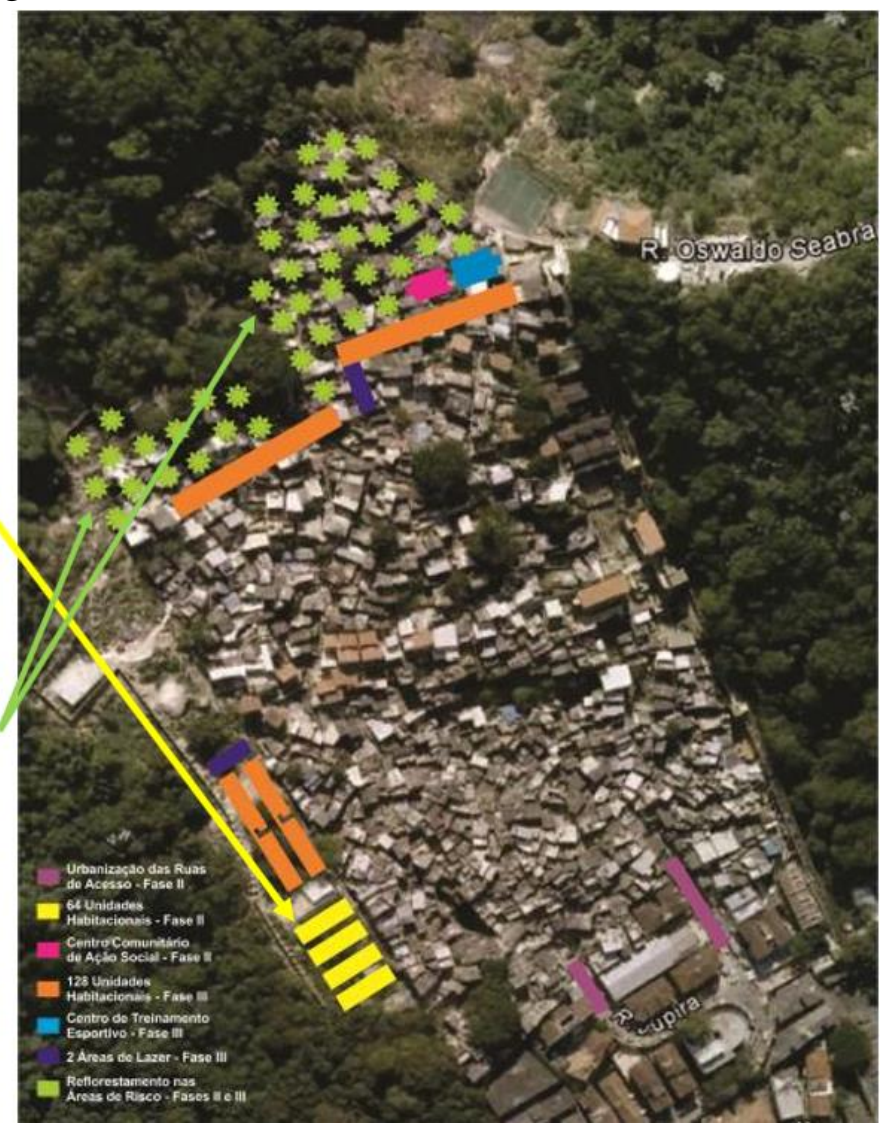

Source (ERJ 2012).

The January 2012 meeting, held in the community hall in lower Santa Marta, announced to residents that the state's plan to implement an urbanization project focused on the Peak residents and their homes. ${ }^{45}$ Peak residents would be resettled to project housing built outside the previous urbanization zone or AEIS on the west side of Santa Marta and once its residents were displaced, the Peak was to be reforested (see figure

\footnotetext{
${ }^{45} \mathrm{I}$ attended this meeting and took notes, but the greater detail is provided via an audio recording provided to me by Rapaz, a local hip hop artist and founder of the Santa Marta community radio.
} 
4.3). The meeting was attended by the vice-governor of Rio de Janeiro, Luiz Fernando Pezão (Elected governor in 2014), and a municipal architect. The president of the resident's association, Hilario Jose Mario, took the role of host and opened the floor to questions from residents after the presentation. The responses were critical; residents questioned why the state had waited for more than 2 years after the installation of the UPP to make improvements to Santa Marta; why it was necessary to resettle all of the residents of the Peak; and how the state would decide which residents would be eligible for new homes in the project housing. While some residents were clearly interested in the prospect of new housing, others were clearly resentful of their neglect by the state. Residents pointed out that previous housing projects in Santa Marta were constructed poorly and frequently seeped water through the walls due to their location. ${ }^{46}$ Staff from the governor's office also announced that a series of meetings would be held with those residents scheduled for resettlement, to address the "social side" of the remanejamento (resettlement) of the Peak. Information about these residents would be collected and tabulated during this process, at the same time that a new public private organization called "Urbaniza" would respond to concerns from residents.

In what follows, I analyze events after 2008, but I briefly visit the history of urban improvement and resident participation in Santa Marta in order to situate resident responses to the new versions of urbanization plans implemented by the state. I use that analysis to argue that the response of the Santa Marta residents to the area of risk

\footnotetext{
46 These critiques were communicated in a community meeting held in the Grupo Eco building on 11/11/2011, which occurred before I was networked into community meetings on this topic in Santa Marta. See (Grupo Eco 2011) for the first of two videos.
} 
argument has a great deal to do with how the state has carried out previous urban interventions in Santa Marta. Residents wanted a participatory role in how improvements and resettlements were carried out, while the state had a track record of ignoring resident priorities in favor of plans that conform with long held agendas by the government to reduce the size and number of Rio's favelas, especially those visible to property owners in upper class neighborhoods. The new urbanization projects were predicated on the particular alignment of political organization and financial resources in Brazil beginning in 2007, called Programa de Aceleração de Crescimento (PAC I) or Growth Acceleration Program, which marked the first phase of state financed urbanization in Santa Marta.47 There was a delay in the second phase of these urbanization projects in Santa Marta after 2009, PAC II, such that the second phase of urbanization did not arrive to the so called 'model favela' until years after other favelas. I examine these events to present how risk area discourse has permeated the urbanization of favelas in current day Rio. I begin by recounting a key meeting that initiated the second phase of urbanization in Santa Marta and the relevant events that preceded it.

The state of Rio made its first public communication to resettle the Peak at the inauguration of the funicular tram in 2008. The implementation of the UPP project in 2009, which was initiated in Santa Marta as a test program, interrupted the state's urbanization project in Santa Marta and marked the beginning of a three year delay of the

\footnotetext{
${ }^{47} \mathrm{PAC}$ is a federal housing initiative that provided funds for the construction of government project housing, which was an attempt to address the perennial shortage of affordable housing in Brazil's largest cities. The federal government has admitted that it was largely intended as a fiscal stimulus measure.
} 
urbanization project. ${ }^{48}$ During the rainy seasons of 2010 and 2011, the state of Rio experienced landslides that led to the state of Rio prioritizing risk displacement projects throughout the state and city of Rio over the urbanization of Santa Marta. The state returned to Santa Marta in January of 2012 to announce a new phase of the urbanization project to a general assembly called by the residents of the Peak so that all of Santa Marta was aware of the character of the urbanization project.

The general assembly for the resettlement project was arranged like a large conference presentation. There were approximately 100 people in attendance, which according to residents' comments in conversations with me was a low turnout due to the lack of notice and hour of the meeting, at 10 am during a weekday. The audience was comprised primarily of residents of Santa Marta, with a majority of African descent which reflects the demographics of the Peak. There were a large number mixed race residents living in Santa Marta from the northeast of Brazil, who migrated to Rio to work low skilled labor jobs. Many of the recent arrivals rented from residents who were born in Santa Marta (known as cria, a status identity in favelas) and according to the cria residents I discussed it with, these migratory workers participate less in the internal political association and organization of Santa Marta. Three key resident activists were in attendance, Sinhô, Rapaz, and Sabrina. I sat next to Sinhô and took notes, while Rapaz used a journalist's microphone to record the meeting. Key state employees, Vice Governor Pezão, Ícaro Moreno (Director of EMOP, the state infrastructure construction

\footnotetext{
${ }^{48}$ Pezão claimed later in this meeting that this was due to bureaucracy and delays by the federal government to coordinate funding of the urbanization project via the PAC. Together with the 2009 UPP implementation in Santa Marta, the emergency response to the landslides of 2010 and 2011 is an alternative set of circumstances that may have delayed this phase of the urbanization project and diverted funding.
} 
firm), and Ruth Jurberg (Social Coordinator for favelas from the Governor's office), stood beside a large projection screen. Henrique, the UPP-Social agent for Santa Marta, was present along with Ruth's team of two supervisors and their fieldworkers, who were black women from other favelas of Rio. ${ }^{49}$ Ze Mario (President of the Santa Marta residents association) opened the meeting and introduced the state employees. Ze Mario is black, Ícaro Moreno and Ruth Jurberg are both white, and Pezão is mixed race. They stood up one by one and spoke to the residents in attendance using a microphone and then opened a question session afterwards, with residents queuing behind another microphone to the right of the table. Ícaro Moreno used powerpoint to present before and after images of Santa Marta from the urbanization projects completed in 2008, as well as the proposed plan, consisting of images superimposed on a google map image of Santa Marta (Figure 8).

Ze Mario opened the meeting by highlighting resident concerns about the return of urbanization works to Santa Marta. He framed the meeting as a democratic debate to fight for the improvement of residents' living conditions and their right to housing, guaranteed by the Brazilian Constitution. ${ }^{50}$ But he clearly saw the meeting as primarily addressing the residents of the Peak and to convince them that the urbanization plan presented by the state was the best course for them. He repeated several times that

\footnotetext{
${ }^{49}$ Interview with Urbaniza worker on July 1, 2012. Note that Brazilians often use first names or nicknames even in formal situations, I follow that cultural tendency when identifying the vice governor by Pezão (Bigfoot) or Mr. Moreno by his first name. This is especially the case when politicians interact with favela residents.

${ }^{50}$ The right to housing was a theme I encountered in meetings with Dr. Sonia Fleury's research team at the Fundação Getúlio Vargas while discussing the diffused rights of Brazilian citizens.
} 
housing was a right and that the debate will allow the residents to exercise their rights by giving voice to their concerns, but he also emphasized that the residents did not or shouldn't want to fight with the state. "So, this is a hard fight that we want to setup this debate and improve the life of the residents there on the top [The Peak]... but debating with them, aiming.. showing what is best for them, right (Ze Mario 2012)?",52

Exhibiting the political sensibility that made him president of the residents association, Ze Mario declared that his goal for the meeting was that everyone leaves satisfied, the state employees and especially the residents, even though it is clear as the meeting progresses that the state has a pre-defined project with very limited flexibility. He recalls that when the governor Sergio Cabral visited Santa Marta to inaugurate the funicular tram in 2008, the governor declared that the next phase of urbanization would do away with "subhuman conditions" and residents living in wooden houses. ${ }^{53}$ This framed the urbanization of Santa Marta as an humanitarian project that obligated the state to intervene. ${ }^{54}$ Following that visit in 2009 , the prefecture produced a risk map of Santa Marta that constrained every Peak resident by prohibiting new construction and additions to homes. This meant that the wooden houses that Cabral mentioned could not be upgraded and that residents waited more than two years for the urbanization project to

\footnotetext{
51 This is also the operating definition of democracy for the managers of the urbanization project, that is to say providing venues for residents to give voice to concerns without any guarantee of more than a verbal response.

${ }^{52}$ It is unclear at the end whether Ze Mario means debate with the state employees or the Peak residents, leaving it possible that it means both. Debater could also be translated as discuss, but here it is used with an adversarial tone.

${ }^{53}$ Governor Sergio Cabral announced to the press during this event that he would resettle the peak as well.

${ }^{54}$ For an elaboration of the humanitarian framing of this urbanization intervention see (Mendonça 2008).
} 
continue in Santa Marta. Meanwhile urbanization projects were implemented in nearby favelas of Rio like Babilonia.

Ze Mario closed his introduction to the meeting by recapitulating how residents interrogated him on the effects of the stalled urbanization project in Santa Marta:

"What is happening with the people on the Peak, the top part, that are excluded from the social project until now?... So how is the situation of the residents there? Can I build or not? Can I improve my house or can't I? What is happening with the people living on social [subsidized] rent? What is happening with the situation of these residents that live in wooden shacks? What is happening with our basic sanitation? Why are people paying water and sewage and living in the clay, eh?" Ze Mario conveyed the insecurity that residents had experienced during the hiatus in urbanization projects in Santa Marta, with residents who were displaced by the construction of the tram in 2008 losing their subsidized rent while waiting for promised housing from the state. Residents, many earning more in 2012 than they had before, were obligated to pay for state services even as the sanitation infrastructure installed in 2008 proved insufficient to handle the runoff from the rainy season. ${ }^{55} \mathrm{He}$ also made the important point that the Peak residents were excluded from the infrastructure improvements completed in 2008, including lighting, sewage, and water. ${ }^{56}$

\footnotetext{
${ }^{55}$ During my field research, on several occasions I was walking up the stairs in Santa Marta when a cascade of water and trash flowed down the walkway. Many residents refused to leave their homes when it rained for this reason, and also because the open sewage would overflow into the rainwater.

${ }^{56}$ This complaint appeared throughout my fieldwork and interviews with the residents of the Peak.
} 
Afterwards, Ze Mario turned over the meeting to the head of the public works division of Rio de Janeiro state, Ícaro Moreno to revisit the urbanization already completed and the next phase, PAC 2. Ícaro began by stating that he was there to address the problems created by the delay in phase two of the urbanization of Santa Marta and answer the questions of residents. He then quickly announced that there would be a registration of residents mapped in the risk area, "insalubrious" homes, wooden houses, or mixed wood and brick houses. This registration would be used to determine their eligibility to be rehoused in the project housing of the second phase, with priority for those living in wooden or mixed material houses. He described a plan to first construct 64 units in the first phase of urbanization and then another 128 units in the second phase. He then made an key promise that proved to be a point of contention later: "And the people that are up there on top in the risk area, we will talk with Geo-Rio and our geotechnical people in EMOP, we will discuss and see which houses really need and are able to be improved or if they have to be relocated ${ }^{57}$ (Moreno 2012)." Here he expressed the contradiction in the state plan to displace and resettle the Peak residents, which was that the prefecture had already mapped the Peak as high risk area but also stated that they would conduct case by case evaluations of risk on the Peak. He followed up by stating that they would be talking to all those residents of the Peak mapped in high risk areas that could only be addressed with massive retention works or heavy construction, and emphasizing that they would be "showing them the risk." Those that were found to be in a situation of risk would then have the "opportunity" to receive subsidized rent and wait

\footnotetext{
${ }^{57}$ Here Ícaro introduced the term "remanejamento", which can be translated as redistribution or restructuring, but is used interchangeably with "relocation" by state employees later in the project.
} 
for the construction of the new housing units. Even though he states later in the meeting that they decided how to address the Peak more than two years ago, Ícaro emphasized that this entire process would be "democratic and very open" and that the risk mapping would be authenticated later by GeoRio. ${ }^{58}$

Ícaro then proceeded to give a power point presentation on the first phase of urbanization projects, showing each in a before and after picture to project a sense of improvement. Beyond the tram, the state had installed a soccer field with synthetic turf; new houses for those displaced by the tram; an extension of the water, sewage, and electric systems; a wifi system installed near the tram and a renovation of the former daycare on the Peak into the headquarters for the UPP; the construction of leisure areas, retention walls and the "boundary wall". This review of state projects was an introduction to the supposedly provisional plan to resettle the peak residents, presented as rectangular images overlaid on a google earth map of Santa Marta (see Figure 4.3). This graphic showed that the new buildings would be constructed outside the boundary wall and overlaid the entire Peak with green blobs meant to represent reforestation. Ícaro explained that in "the areas where they will relocate people" there will be "reforestation of the devastated areas." He adds that he supports the relocation process, job and income generation, and adds that there will be sanitary and environmental campaigns, land

\footnotetext{
${ }^{58}$ Icaro said at this meeting (January 2012) that the project would be finished in twelve months. The first building still hadn't been finished when I checked in December of 2015.
} 
titling, as well as physical and socioeconomic registration. This was a segway to the next speaker, Ruth Jurberg, the "social coordinator" of PAC 2 in the governor's office. 59

Ruth Jurberg explained that she was responsible for the "social area" of the resettlement process that would register and survey residents of the peak mapped in the risk area. To attend to the residents rights and alleviate their anxieties, Ruth's team set up a canteiro social (social kiosk) for residents to stop by and ask questions at the fourth station of the tram. ${ }^{60}$ She then explained what her team would be doing until the new buildings were constructed: "The first job that we are carrying out here... is mapping [read surveying] the families up there on top, in the risk area, but the families that GeoRio indicates are in the risk area; it will not be all the families that have to leave, only the families that live in a precarious condition and in risk areas (my italics)." She finished by giving the specifics of the subsidized rent, which was 400 reals per month until the construction ended, and added that the social work of her team would continue six months after the construction. Both Ícaro and Ruth highlighted the subsidized rent, which meant that residents would leave their homes as soon as the residents were "mapped" and then wait for the construction to end. After the project was presented, Pezão weighed in to explain the delay in the urbanization project, and he also highlighted the subsidized rent, arguing that the economic situation in 2012 was the first time that

\footnotetext{
${ }^{59}$ Ruth Jurberg has a background in Architecture and Urbanism and worked her way up from local planning in government agencies. Interview carried out by Dr. Sonia Fleury on April 20, 2012. PEEP archives.

${ }^{60}$ This is not the correct translation of canteiro, which is a strip of tilled earth in a garden or construction site. I visited this canteiro, and it was set up as a kiosk with folding chairs and a large umbrella for shade along the path way crossing the top of the favela. When I asked, the employees said that not many residents had come with inquiries.
} 
Brazil had the finances to carry out the scale of housing construction and resettlement programmed through PAC 2. He promised to stay in Santa Marta for three years with the "greatest will" to see the project through to its completion.

Pezão then turned to the issue of resettling residents from risk areas, but communicated in a way that did nothing to alleviate the anxiety of the residents of the Peak about losing their homes, arguing that "until we learn to dispossess areas and construct worthy housing, we will take a long time and have a lot to do, even worse in an ingrown community like this one with a difficult topography and environmental situation." Pezão warned against poorly planning and constructing public buildings in risk areas, which became a point of contention at the GeoRio presentation, stating that "It is not an advance if we take a wooden shack from someone in a risk area and construct an apartment in another risk area (Pezão 2012).” This comment provided a glimpse into his perspective of the problem of Rio's favelas, that the difficulty in resettlement was in getting residents to let go of their previous homes and arrange for a parcel of land for the new buildings, often located in a pre-existing Environmentally Protected Area (EPA) or risk area requiring mitigation before building. Here Pezão commented on the urban geography of Rio, remarking that Rio is unusual in that the poor occupy the hills, a city where all the best lowland has been developed by the upper class and the remaining highland has been mapped in EPAs, even though upper class developments occupy more space and are also located in risk areas (see Figure 3.5). He closed with an attempt to assuage the anxieties of Santa Marta's residents by declaring that "Nobody here wants to take the livelihood of anyone; nobody wants to dispossess anyone; nobody wants to remove anyone from here; We want for you all to live in dignity and safety, giving land 
titles... giving a guarantee to you all, a thing that you all don’t have (Pezão 2012).” While this addressed the issues that Ze Mario mentioned at the outset of the meeting, his final comment reminded residents that they lived with insecure land tenure and they were subject to the rule of the state, which can grant land titles or deny them.

Following Pezão's comments, they allowed residents to ask questions and make comments or complaints. Rather than follow in sequence, here I will interrupt the temporality of the narrative to turn back to the events and community organization after 2001 that preceded the return of urbanization interventions and especially a community meeting held in Santa Marta in November of 2011 in anticipation of the return of the urbanization project in 2012. The discourse presented in that meeting situates the residents' responses in the history and politics of Santa Marta. ${ }^{61}$

${ }^{61}$ I did not attend this meeting, I was given several accounts by my interviewees and the meeting was filmed and uploaded onto youtube. 
Community organization before the return of urbanization

Figure 4.4: 2003 Santa Marta resident designed urbanization committee plan.

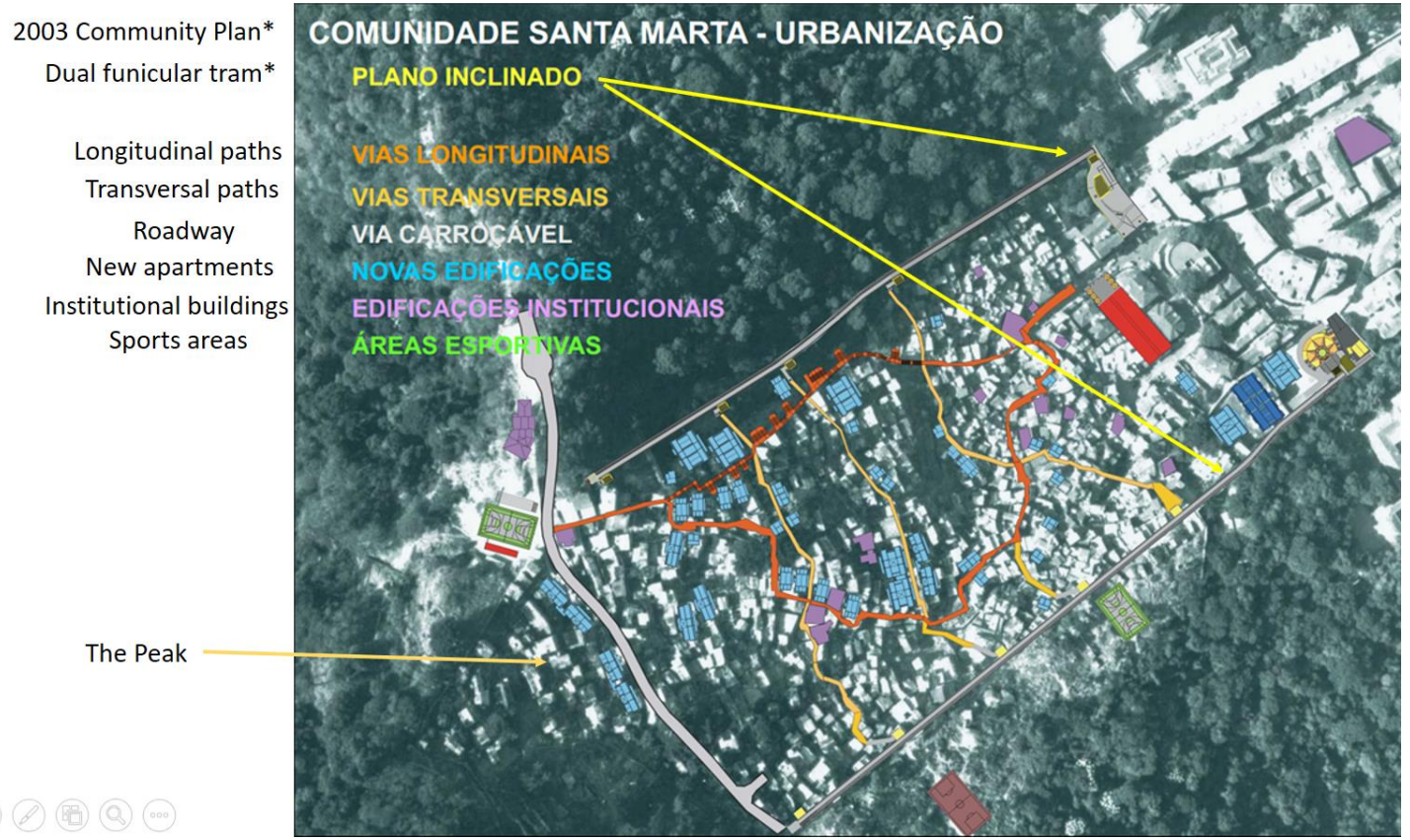

(Salles 2011) *Additions to image by author.

In 2004, the state of Rio began a new urbanization project in Santa Marta that it claimed was formed from an urbanization plan formed by a collaboration between the architect Fernanda Salles and the Santa Marta urbanization committee made up of residents and activists from Santa Marta, independent from the residents' association (see Figure 4.4). The Santa Marta urbanization committee met from 2000-2003 to identify urbanization improvements using resident participation and their design was specifically oriented towards improving the life of Peak residents. It is important to note that Fernanda Salles won a public contract with the state of Rio in 2003 to design Santa Marta's urbanization plan, and that no mapping of the Peak as a risk area had been 
disclosed by the prefecture before the urbanization project began in $2004{ }^{62}$ According to Itamar Silva the urbanization committee never saw the final plan before the contract with the construction company was signed in 2004 (TV Favela/Grupo Eco). The plan the state used for the 2004-2008 interventions removed the second tram residents proposed on the west side of Santa Marta (see Figure 4.5 below). The plan clearly showed the Peak resettled and reforested with new buildings below the transversal pathway from the fifth station, but the first phase of the PAC did not include Peak resettlement. The governor of Rio brought the plan to resettle the Peak to the forefront during the 2008 inauguration of the funicular tram in Santa Marta (EMOP 2008; Mendonça 2008). In contrast to previous communications in 2004 that called for the resettlement of only those living in wooden houses, governor Cabral announced that the state of Rio planned to resettle all those living in wooden houses on the Peak, and so residents began to organize a response.

${ }^{62}$ Interview with Itamar Silva carried out by Dr. Sonia Fleury in September of 2011 at the FGV. PEEP archives. 
Figure 4.5: Fernanda Salles 2004 post state contract plan.

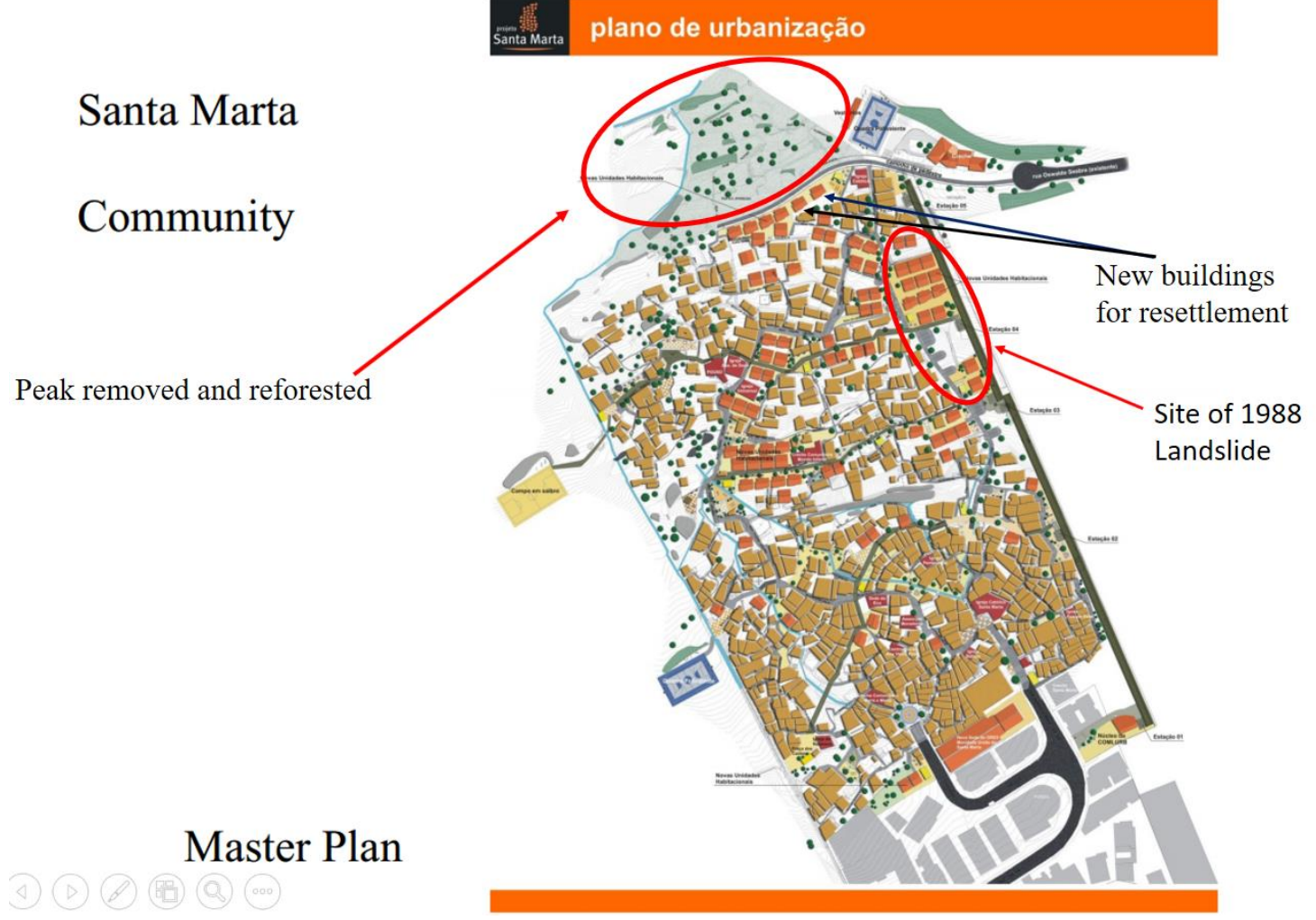

Morar Carioca plan adopted for the urbanization works from 2004-2008. In 2007 it gained federal funding under the PAC which accelerated the schedule and expanded the types of projects that were funded. Plan from circa 2004.

When President Luiz Inácio Lula da Silva visited Santa Marta on February 3, 2009 to inaugurate the new housing constructed for those displaced by the tram and announce the next phase of the "reurbanization", Itamar Silva used the opportunity to deliver a letter that called attention to the exclusion of the Peak from the urbanization interventions and its slated resettlement in the next round of projects (Mendonça 2009). ${ }^{63}$ In that letter, Itamar questioned the knowledge claim of the "area of risk" and argued that the state should improve the Peak residents' homes and infrastructure without

\footnotetext{
${ }^{63}$ See appendices for full text of this letter. This letter was emailed to the residents of Santa Marta via a listserve and I obtained a copy from a resident who received it.
} 
resettlement. Onsite improvement of existing homes would maintain residents on the Peak, which has historical significance as the original site of settlement for Santa Marta according to its oldest residents. ${ }^{64}$ Itamar emphasizes the Peak's historical importance as he writes in his letter:

"Our argument is that it is possible, technically, to do the necessary mitigation works, keep the existing and already upgraded homes; and reconstruct those houses in a precarious state and so preserving an important part of the history of the favela Santa Marta. And this permits those residents that suffered most during the absence of the State, to be able to now benefit from the improvements that come to the Favela."

Critically, he requested that the government include resident participation in the urbanization project. Resident participation in resettlement projects was a right recognized in federal legislation from the 2001 Estatuto das Cidades (Cities Statute) in the section on the right to housing, which closely resembled the right to housing principles promoted by the United Nations (Olinger 2015, 81). While Itamar's letter did not generate the media controversy of the ecobarrier, the delivery of the letter to Lula increased the awareness of the Peak issue for residents who lived lower on the hill and put the state on notice that the residents were asserting their rights as Brazilian citizens. During Lula's visit in 2009, plans to construct new housing in Santa Marta were announced, but the urbanization project was not implemented until 2012. Many Santa Marta residents felt that this was neglect to the so called model favela.

${ }^{64}$ Interview with Marcos on September 14, 2012 
The residents first received confirmation of the return of urbanization in September of 2011, during the meeting in the Quadra of Santa Marta to initiate the UPPSocial program, a World Bank, United Nations, and prefecture coordinated project with a stated mission of “integrating” Rio's favelas with UPP into the city of Rio (Cunha and Mello 2011). ${ }^{65}$ Beginning in 2010, the UPP-Social teams were hired and led by members of the Instituto Pereira Passos, Rio's municipal think tank for urban issues (World Bank 2012c). While the program's institutional goals were to consolidate state control and integrate favelas into the city of Rio, from what I observed in later meetings and events, in Santa Marta the UPP-Social was primarily focused on formalizing businesses and arranging corporate partners for cultural projects. During their first meeting in the Quadra, the employees of the prefecture present made it clear at that meeting that the Peak was slated for resettlement in 2012 and that the state of Rio would be managing the resettlement. ${ }^{66}$ The meeting was attended by community leaders and activists from Santa Marta, who then planned how to raise awareness and organize Santa Marta's residents for the coming urbanization intervention.

With that in mind, in November of 2011 the resident activist Itamar Silva called a meeting of Santa Marta residents potentially effected by the return of state urbanization projects in 2012, whom were primarily from the Peak. ${ }^{67}$ Silva informed the attendees that

\footnotetext{
${ }^{65}$ Interview with the United Nations Habitat Coordinator Fernando Patiño in Rio de Janeiro on August 10 , 2012.

${ }^{66}$ Audio recording of this meeting by the Santa Marta Radio, provided by Rapaz.

${ }^{67}$ Itamar Silva was a long time resident activist and community organizer in Santa Marta with a background in journalism and was employed at a public/private think tank on social issues called IBASE.
} 
he had requested that the state present its plan to the Peak residents in an open meeting to all residents of Santa Marta for debate and that the state was required to present its plan for feedback and participation by Brazilian law. Since the state announced its intention to remove all of the Peak in 2008 and the prefecture had remapped all of the Peak as a risk area in 2010, Itamar advised the attendees that they should prepare themselves for a state project to resettle the entire peak and emphasized that it was crucial for the Peak residents to organize their response prior to the upcoming open meeting. He called for all the residents of Santa Marta to show solidarity with the Peak residents, considering that the state could displace the Peak and then later push for a new round of removals farther down the hill. ${ }^{68}$

In response to a resident that expressed concern that some residents' homes were falling down from disrepair, Itamar reminded the residents that since the UPP installation in late 2008 , the state had prohibited repairs for three years and that people who are living in difficult situations tend to accept any offer of improvement from the state. He argued that it was important for the residents to resist the initial proposal of the state to get the best result even if some residents are willing to leave the peak for a new house. Itamar then outlined the major points that needed to be contested with the state:

1. They needed to counter the risk argument itself since the state had already invested large amounts of money in Santa Marta to mitigate the risk in previous urbanization interventions. He suggested that they question whether the previous intervention was

\footnotetext{
${ }^{68}$ The prefecture used a piecemeal strategy to reduce the favela Estradinha/Tabajaras to a small fraction of homes just one year prior, and this favela is visible from the Peak of Santa Marta. Many residents had familial and work connections to Tabajaras.
} 
poorly designed or if the state did not control the quality of the construction, if so the state had an obligation to correct those issues.

2. The state had previously constructed resettlement housing near the fourth tram station that was previously mapped as a risk area. This demonstrated that the state had the capability to construct homes on the peak even if it was mapped as a risk area.

3. They need to push for the largest possible apartments since previous resettlement projects had resulted in 32 meter square apartments. The Housing Movement of Rio argued that the minimum size of any resettlement housing should be 42 meters squared. Itamar informed them that the process of contracting the construction firm allowed for changes from resident feedback even though there was already a bid for the new project by the construction firm Venta Sul, the same firm that had constructed the ecobarrier.

4. There were residents displaced from the urbanization project completed in 2008 that only received subsidized rent for three months. Residents should make it clear that they will only move from their homes after the new project housing is completed as residents that accept subsidized rent could find themselves homeless if the state stopped paying subsidized rent.

To drive home this last point, Itamar reminded residents that the residence known as Salvador House near the fourth station in Santa Marta was a wooden shack that the state wanted to resettle with the previous urbanization project. The resident refused to move to the tiny apartments mentioned above and later was rewarded with a social project that built a better more spacious home on the same site. He used this example to remind the residents what had been accomplished by resisting the first plan offered by the 
state. He concluded by highlighting that the state had made improvements to the quality of life on the Peak during the urbanization that ended in 2008, so it was important to fight to live there. Afterwards, a peak resident informed those present that the Peak Committee had formed and met the previous week and "defined what is best for the Peak". The resident presented the following priorities of the Peak Committee:

1. The right to remain on the Peak

2. The right to make home improvements without interference from the POUSO (municipal zoning office) installed in Santa Marta after 2009.

3. Urbanization improvements to the Peak including: Paved paths, containment walls, connection to the city water system, the end of water cutoffs, and the installation of new light posts. ${ }^{69}$

4. Trash collection that doesn't neglect the Peak residents.

The residents' association president Ze Mario spoke at the end of the meeting and reported that he had gone to the governor's office to relay residents' anxieties about the resettlement proposal and the prohibition on home repair and additions. Ze Mario was told by the governor that members of his government were preparing the state's “technical presentation" of the urbanization and resettlement project for Santa Marta's residents, with a budget of forty million reals.

${ }^{69}$ Residents of the Peak were paying for electricity but the company contracted by the prefecture refused to maintain the lighting system. 
This meeting showed me that Santa Marta's residents were organizing in response to the notification about the coming meeting and that they were preparing based on past experiences with urbanization interventions in Santa Marta. They understood that the exclusion of the Peak from the 2008 urbanization project was a sign that the government did not support the right of Peak residents to remain there. Their strategy was to contest the government's arguments as a means to produce the highest quality work by state institutions on the urbanization project, in light of previous low quality projects carried out in Santa Marta under previous administrations. Itamar showed a very low level of trust for government programs and attempted to prepare residents for government failures and contradictions in the future. Both Itamar and Ze Mario were cognizant that the state had to recognize residents' rights more than any time in the past considering that the state had held up Santa Marta as a model for government programs in Rio's favelas. The Peak residents' reaction during the general assembly reflected the organization meeting held weeks earlier.

\section{Resident responses to the urbanization plan at the general assembly}

Here I will return to the question and answer portion of that "technical presentation" where residents made known their experiences over the past three years the government had delayed Santa Marta's urbanization improvements. The issues recalled by the residents fell into three groups:

1. Infrastructure neglect and its geographic unevenness.

2. The prohibition on home improvements in Santa Marta that began in 2009.

3. The displacement of residents mapped within the high risk zone. 
The resident Marcos, whose family had lived on the Peak more than seventy years, showed that he was aware of the uneven infrastructure provision that neglected the Peak and that he had been following the risk mapping process closely. He recalled that GeoRio's 2010 onsite re-evaluation of risk in Santa Marta found that "the region above 140 meters is notable for the absence of infrastructure, without paved pathways, without a sewage system. I understand this here as an abandonment by all the governors who came through here." Here he emphasized that the condition of the Peak was the direct result of failures by previous administrations of the state of Rio to fulfill their obligations to improve Santa Marta's AEIS under the federal City Statute promulgated in 2000. The condition of residents homes was also used as one of the criteria for the high risk classification, as I discuss in chapters four and five.

Peak resident Tania questioned why there are frequent water outages since the state ostensibly urbanized the water system, she punctuated that "We that live on the Peak, live close to the water reservoir and we don't have water. Before we never lacked water, understand?" Water shortages of hours or days were a frequent complaint during my field research. The Peak residents had worked with the Catholic Church to construct a water reservoir and install a pump in the 1970s (Silva 2003). Tania recalled that the resident built infrastructure had never resulted in outages before the UPP, even though my research found that the Peak was more populated during that period. She added that despite paying for electric service, the municipal electricity firm never acted on a promised to illuminate their stairs and some of her neighbors on the Peak did not have light. She asked why they paid for electricity and water, yet had to "beg to receive the 
service?" and further suggested that the state should be more concerned with improving the community than with demolishing houses.

Pezão responded that the state couldn't allow construction on the Peak due to legal restrictions, "We have a limitation, the law doesn't allow construction above the Cota Cem (One Hundred Meter Limit) (Pezão 2012)." If this juridico-political principle was applied to all of the residences above the One Hundred Quota, nearly half of Santa Marta's residents would be prohibited from making improvements and their residences would be ineligible for tenure legalization, as the one hundred meter mark is located just above the third tram station and the Peak is largely above the fourth and fifth stations. I pointed this out in informal meetings with the Peak residents in 2012, who were quick to recognize that if the city threatened to remove the upper half of the favela that it would quickly lose the support of the residents' association for the urbanization project. Recognizing the infeasibility of a strict enforcement of the One Hundred Meter Limit, residents were keen to expand or improve the quality of their homes after a period of prosperity in Rio's favelas that followed the commodity boom of the 2000s.

Sabrina, who was a frequent and articulate critic of government policies and performance in Santa Marta, related that she and other residents have been saving money and materials to improve their homes for years, but were prohibited by the POUSO without explanation. She cited the lack of clarity and criteria for what was allowed since the UPP installation in December 2008, and emphasized that residents needed reliable information so that they can improve their homes. Another resident recounted the effects of the poor quality of the existing and limited water and sewage system, which had 
sprung leaks and damaged people's homes. She stated that the POUSO (onsite building code enforcer) prevented her from repairing the roof, leaving her grandfather living in sewage and her children's room moldering. She added that the POUSO threatened to demolish her house if she fixed her roof. Pezão responded that CEDAE, a municipal institution, was responsible for the water and sewage infrastructure, and blamed the previous prefect, Cesar Maia, who was in charge of the public water firm in 2007 when the state's urbanization projects were in process. My view after reviewing my field observations and interviews was that Pezão used the complicated politics of scale in Santa Marta to dodge responsibility. The lower part of the favela is governed by the municipality, but the Peak falls within the jurisdiction of the state of Rio, which was why the state was carrying out the latest urbanization plan that specifically targeted the upper portion of the favela. Residents were understandably confused, but the state had anticipated that confusion and delegated a mediating role to Ruth Jurberg.

Ruth claimed to understand that the communities' issues have been pushed to the side since the government has been absent for two years in Santa Marta. Ruth asked for patience since they had been struggling for approval of the urbanization project for two years, and they finally had that approval in 2012. Ruth Jurberg echoed Pezão's comments in the meeting that the POUSO fell under the prefecture's jurisdiction and was based on decrees made by the prefecture. She stated that the state intended to "dialogue" with the prefecture to mediate these issues of confusion on the building rules. She announced that her team was documenting all of these demands and would attempt to address them "in the field", that is to say with the social kiosk and meetings with residents. Area of risk critiques enveloped these meetings, as I describe in chapter five. 
Peak residents, whom were effected by both potential improvement bans and displacement plans predicated on risk mapping, had prepared a robust critique of risk mapping. After seeing the google earth projection of Santa Marta with the peak covered by the reforestation symbols, Fabio responded in the meeting by vigorously contesting the mapping of the Peak as a risk area in this quotation:

Here I saw on the map... that the whole area where I live, we live, that area will be reforested... I want to know what is the theory that you have used to say that we live in an area of risk, eh? Because there are houses collapsing in the suburbs around here, with torrential rains and our house is still standing... There where we live, we look towards Mundo Novo and see an immense mudslide next to a mansion and nobody has said that mansion is in a risk area. Here in Humaitá... a mansion practically fell in half from above, blocking the quadra (courtyard), and nobody says that [Humaitá] is a risk area (Fabio 2012).”

Here Fabio cited the wealthy residences in adjacent neighborhoods that had more occurrences of landslides than the Peak of Santa Marta. The history of events was a key criteria of the risk justification in GeoRio's presentation six months later. Fabio foreshadowed that argument by presenting his knowledge of the history of the Peak. He questioned the government panel from the microphone provided "Do you have some record of a serious collapse [On the Peak], understand?", and he attested that he has "lived there forty-eight years and nothing has ever fallen." (Fabio 2012)." The focus on event history put the popular understanding of risk as depending on previous landslide 
events in contradiction with GeoRio's account of the calculation of risk, which used the same criteria inter alia.

In his response to Fabio's critique, Ícaro argued that the risks had increased due to climate change and as the result mitigation efforts that cost millions of dollars weren't sufficient to guarantee the safety of residents of mapped within high risk areas:

"Because nothing has fallen until now doesn't stop it from being an area of risk; it is not because of this. The rains have this intensity now, the climate changed. In the Serra region [nearby cities of Rio state hit worst by the landslides in 2010-11], there are houses that you see on the hillside, everything is up to standard, everything right, and thousands of people died."

Ícaro argued that moving to a safer location to "another apartment in "better condition" was preferred by the state over spending millions of dollars on residences the state has mapped as high risk. Thus, Ícaro shifted from landslide risk to the cost of improving safety, which according to him was not guaranteed. This argument revealed that financial calculations are a part of the risk assessment made by the state in risk mapping, not just the threat to lives. To reinforce his argument, Ícaro appealed to the authority of Geo-Rio, stating that it was an internationally recognized institution and that EMOP was going to debate the risk issue with Geo-Rio. He further promised that Geo-Rio and EMOP would present the resulting assessment in Santa Marta for the residents to debate. He guaranteed that no action would be taken before the residents were made highly aware prior. Like Pezão, Ícaro also cited the complicated jurisdictions involved in authorizing the new location for construction, as well as the verification of the risk level, as reasons for the 
delay of the urbanization project in Santa Marta. ${ }^{70}$ After Ícaro finished his response to resident concerns, Ze Mario concluded the assembly by reassuring residents that he would advocate to the government that those with well-built homes would be able to remain and only those "in a situation of risk" would need to leave.

\section{Conclusion}

In this chapter I have reviewed the events the led up to the resettlement intervention that I observed during my fieldwork, focusing on the ecolimits and ecobarrier. I have shown that Rio's urban policy apparatus has long attempted to control favela space and populations and that we are currently in a new series of attempts to control Rio's favelas framed in environmental discourse. The ecolimits co-emerged with the AEIS, the area of risk political technology, and the urban upgrading of favelas. Meaning that area of risk has become entangled with urbanization interventions in Rio. Area of risk has become the most important and primary means of favela control in Rio, the risk resettlement project in Santa Marta is important because the state has framed Santa Marta the model favela, meaning that it is drawing lessons and using Santa Marta as an example of the state's ability to control favelas. To make that case, I have examined here how the state initiated its resettlement program in Santa Marta and how residents responded to that program.

\footnotetext{
${ }^{70}$ My examination of the iteration of urbanization plans in state documents shows that urbanization plans beginning in 2004 planned to build new buildings within the current limits of the favelas, which would have required demolishing a large number of existing residences (See Cunha and Mello 2011). The plan presented at this meeting located the new buildings outside the limit of the AEIS, in an area mapped as an EPA.
} 


\section{Chapter V: Discourses of Risk and Urbanization in Santa Marta}

This chapter provides an account of the resettlement meetings for the Peak residents and their responses to the landslide risk arguments used in those meetings. The chapter is divided into three sections. The first section describes how the resettlement meetings were conducted and the DRR programs that were mobilized. These meetings were organized and carried out by Urbaniza, a Public Private Organization (PPO) contracted by the state of Rio, which I introduced in the previous chapter. This was a series of meetings from March-June of 2012, followed in July by a meeting with GeoRio, the municipal disaster planning and response agency for Rio. The second section examines the resident responses to those meetings, which became an important site of my ethnography, focusing on the critiques used in the meetings and the events that were organized throughout my field research by the Peak residents to defend their right to live on the Peak. The critical responses were made by residents during the meeting with GeoRio, the meeting to discuss the release of the counter assessment of risk in Santa Marta, and a resident organized event to increase awareness of the pending resettlement and solidarity for Peak residents called the "Hike Against Removals". In the third section, I analyze the residents' counter discourses using a four-part typology: Historical, Visual, Participation and Technical. I then explore the relationship between counter discourses and the assemblage framework from chapter two.

Following the general assembly meeting in January, Urbaniza employees circulated in the favela and registered Santa Marta residents that wanted to apply for a 
place in the new project housing apartments. Residents were asked about their income levels and the condition of their houses and were encouraged to apply for social benefits. Despite a declared mission of fulfilling the "social side" of the resettlement, the process of registering vulnerable residents prior to the construction of the project housing had the effect of increasing the psychological insecurity of these vulnerable residents. ${ }^{71}$

Residents, who had a long history with previous urbanization projects in Santa Marta and their unfulfilled promises, were uneasy with giving their information without a concrete commitment to provide alternative housing. The Urbaniza employees that collected this data, residents of other favelas of Rio de Janeiro for the most part, were instructed not to respond to questions and focus on obtaining information. ${ }^{72}$ Furthermore, Urbaniza employees were instructed to give four options to residents targeted by the urbanization project; first, habitação social (resettle to the project housing), second, compra assistida (subsidized purchase) of housing in another location, third, indenização (indemnification or compensation) for the value of the materials used to construct the residents home (which did not include labor or for the value of the terrain underneath), and fourth, aluguel social (subsidized rent) in another location. Only the habitação social promised to resettle vulnerable residents onsite in Santa Marta.

The experience of being presented with these options by the Urbaniza team as they carried out their socioeconomic survey increased the realization that Peak residents were going to be displaced and that some unknown form of housing was in their future.

\footnotetext{
${ }^{71}$ Author's interview with an Urbaniza employee on July 1, 2012

${ }^{72}$ Ibid. This employee suggested that this process should have occurred after the new homes were constructed to alleviate anxiety.
} 
To further their awareness of the looming threat of resettlement, a map showing the Peak as a risk area along with a poster on the coming construction project was put on the wall of the residents' association near the mailboxes (see Figure 5.1). ${ }^{73}$ This same poster was used during the general assembly meeting and touted decreased occupation of areas of risk and reforestation. The residents' association was a key point of circulation for all Santa Marta residents, so the risk map was a powerful visual statement that presented the risk as a fait accompli to the Santa Marta residents. In the meetings, Urbaniza informed residents that anyone whose home was constructed of wood or a combination of wood and brick had first priority in the new project housing (see Figure 5.1). Residents who expressed concerns were directed to attend meetings held on the resettlement by Urbaniza.

These meetings, called to prepare residents for the resettlement, held from April until October of 2012. In the meetings, Urbaniza's employees disclosed that it was an engineering firm from São Paulo that had hired residents of other favelas to collect data on vulnerable residents that were to be resettled to the housing project. Frida, the primary contact for Urbaniza, asked for residents sign up for three different committees at the first Urbaniza meeting after the general assembly: 1. Acompanhamento (feedback on the project housing construction) 2. Renda (employment and income generation), and 3. Remanejamento (resettlement preparation). ${ }^{74}$ The resettlement meetings that I attended were contentious affairs. Employees of Urbaniza attempted to discuss what would happen

\footnotetext{
${ }^{73}$ Observed when I interviewed the residents association president on September $12^{\text {th }}, 2012$.

${ }^{74}$ Participant observation at the April 12, 2012 Urbaniza meeting.
} 
during the resettlement, but residents from the Peak, unconvinced that they lived in a "risk area", frequently steered the proceedings towards the risk justification.

Figure 5.1: Map of homes scheduled for resettlement on the Peak.

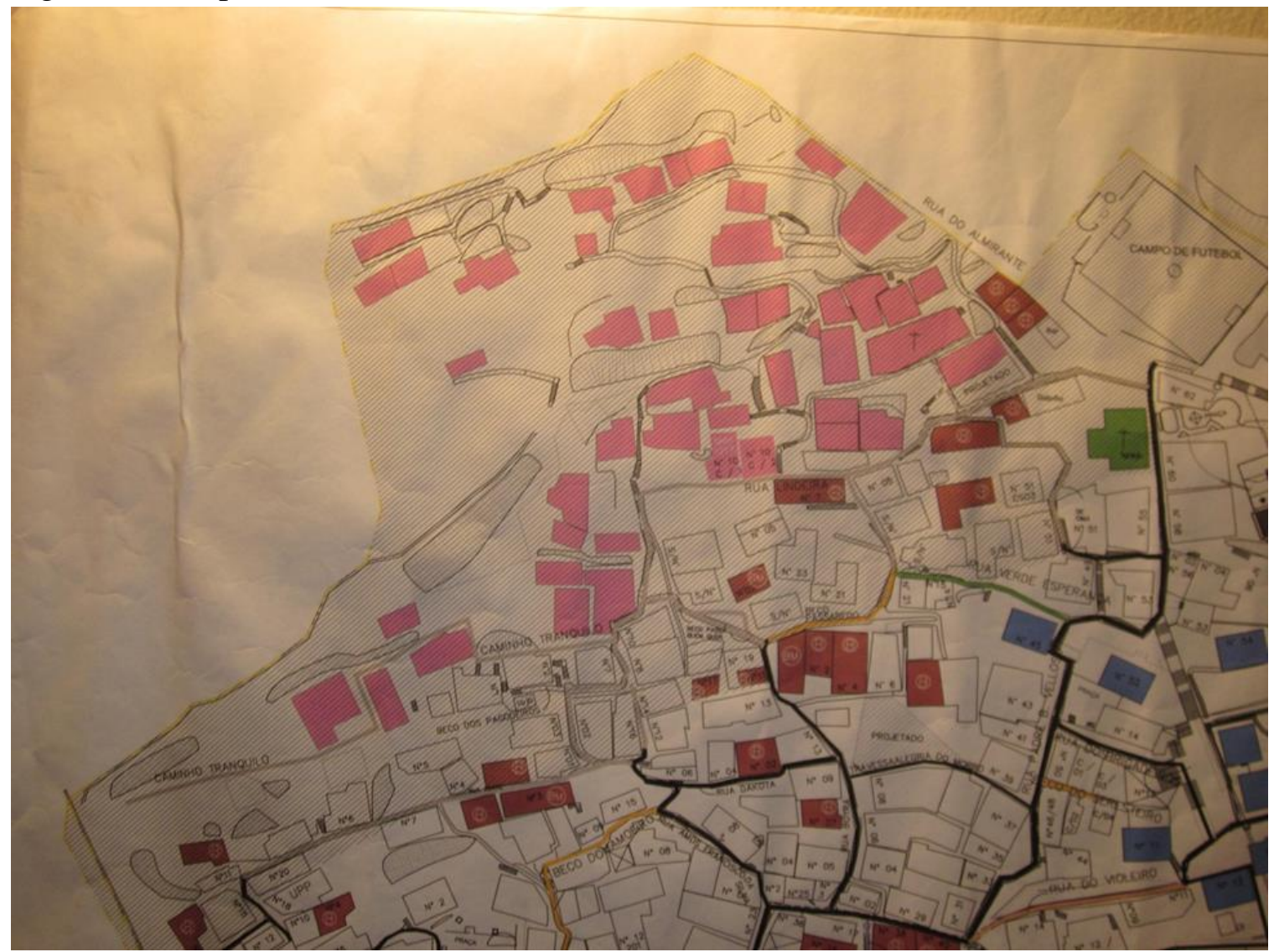

Reconstructed Key from bottom of the map. Photo taken on March $9^{\text {th }}, 2012$.

Crosshatched areas: Area of high risk according to GeoRio.

Houses shaded pink: Self constructed houses to be resettled after a new evaluation of risk from EMOP.

Houses shaded red: Wooden shacks or mixed of wood and brick. First priority for resettlement to the new project housing.

To show why they questioned the risk assessment, residents pointed out that the

Peak had never experienced a landslide since the founding of the favela in the 1930s.

Residents questioned how the state had built the current headquarters of the UPP in the high risk area next to the Peak and asked why it was not possible to mitigate the risk with 
the same construction techniques for their homes. They rejected assertions that the flow of water from the hill above augmented the risk, as previous urbanization projects implemented by Rio de Janeiro state administrations in the early 2000s had constructed a canal system that diverted water flow outside the western border of Santa Marta. After the repeated questions disrupted the meetings, the remanejamento meetings were discontinued until July of 2012, when residents were called on short notice to the UPP headquarters for a meeting with the lead geologist for the Geological Institute Foundation of Rio de Janeiro (GeoRio), which both assesses disaster risk in the municipal area of Rio and also manages efforts to mitigate that risk. The location of this meeting in the UPP headquarters was a discouraging choice that deterred participation by making it more difficult for residents that lived at the bottom of Santa Marta and also due to the fact that some residents were intimidated by the UPP. This was brought up by some attendees during the meeting.

Naturalizing and mapping risk in Santa Marta: The GeoRio meeting.

"That risk [threatening the Peak residents] is associated with the settlement and a process working through millions of years - this has nothing to do with bureaucracy—we use a methodology applied internationally."

- Nelson Meirem Nelson, lead GeoRio geologist.

[Nelson] "brought a series of maps, showed how it [the latest risk mapping] was made, how it was produced... as an expert, he studied for this."

- Ruth Jurberg, social coordinator for favela urbanization programs 
In meeting to present the risk mapping of Santa Marta, the GeoRio geologist Nelson Meriam Nelson presented the argument that the Peak residents lived in a risk area. The meeting was arranged by Ruth Jurberg, the "social coordinator" for the federal government Growth Acceleration Program (PAC in Portuguese) that financed the urbanization program in Santa Marta managed by the governor's office. Ruth introduced Nelson as the foremost expert on risk areas and also on the risk in Santa Marta. ${ }^{75}$ Nelson began his presentation by stating that he was not there to convince the residents, but rather to neutrally explain his work and the history of risk in Santa Marta. He emphasized that, more importantly, GeoRio's objective was to safeguard the lives of the residents of Santa Marta. Nelson used the discourse of risk to assert that the portion of Santa Marta above the fourth tram station, where a majority of the Peak residents lived, was in a high risk area. His central claim was that risk was an essential property of the geography of Santa Marta, and that the residents of the Peak had both put themselves in the path of that risk and exacerbated that risk by modifying the landscape. The following is an account of that meeting and how risk was naturalized by Nelson in order to convince, despite his denial of doing so, the Peak residents of the danger of living in the space of the Peak.

Nelson began his presentation by affirming his extensive experience in Santa Marta, stating that he was there to dialogue with residents and that his primary concern was the safety of the residents. Nelson recalled that GeoRio carried out the first "qualitative" risk mapping of Santa Marta in 1986, as part of the first project to map risk

\footnotetext{
${ }^{75}$ Participant observation at the 7/03/2012 meeting in the UPP headquarters at the top of Santa Marta.
} 
in several of Rio's favelas using visual surveys. ${ }^{76}$ Starting from that point, Nelson recounted the history of previous interventions and risk assessments done by GeoRio in Santa Marta. He began with GeoRio’s efforts in the mid-1980s to identify and mitigate risk in Santa Marta before the 1988 intense rains that were followed by landslides in Santa Marta and several other Rio favelas. The 1988 landslide occurred below the Peak in a portion of Santa Marta where homes were constructed on a former landfill (see figure 5.2). GeoRio was in the process of constructing mitigation works in Santa Marta when the heavy rainfall precipitated the landslide and killed 12 people under four meters of landfill detritus. ${ }^{77}$ Nelson recounted that following the 1988 landslide, GeoRio constructed a canal system to divert rainfall outside the favela and containment works around unstable boulders and rock faces in Santa Marta. Nelson affirmed that these risk mitigation measures changed the risk level within Santa Marta. ${ }^{78}$

\footnotetext{
${ }^{76}$ A crude version of the qualitative risk map was shown in Nelson's presentation along with a picture of the 1988 landslide in Santa Marta. See image below from Ricardo D’Orsi’s presentation.

${ }^{77}$ Jornal Do Brasil. February 13, 1988. Page 4. Dona Marta tem hoje menos gente e menos barracos.

${ }^{78}$ Community trash collection, the garis comunitarios, was also a favela program funded by the state after the 1988 landslide to reduce accumulated trash. Interview with former gari comunitario on November $15^{\text {th }}$, 2011.
} 
Figure 5.2: 1988 Landslide at Santa Marta.

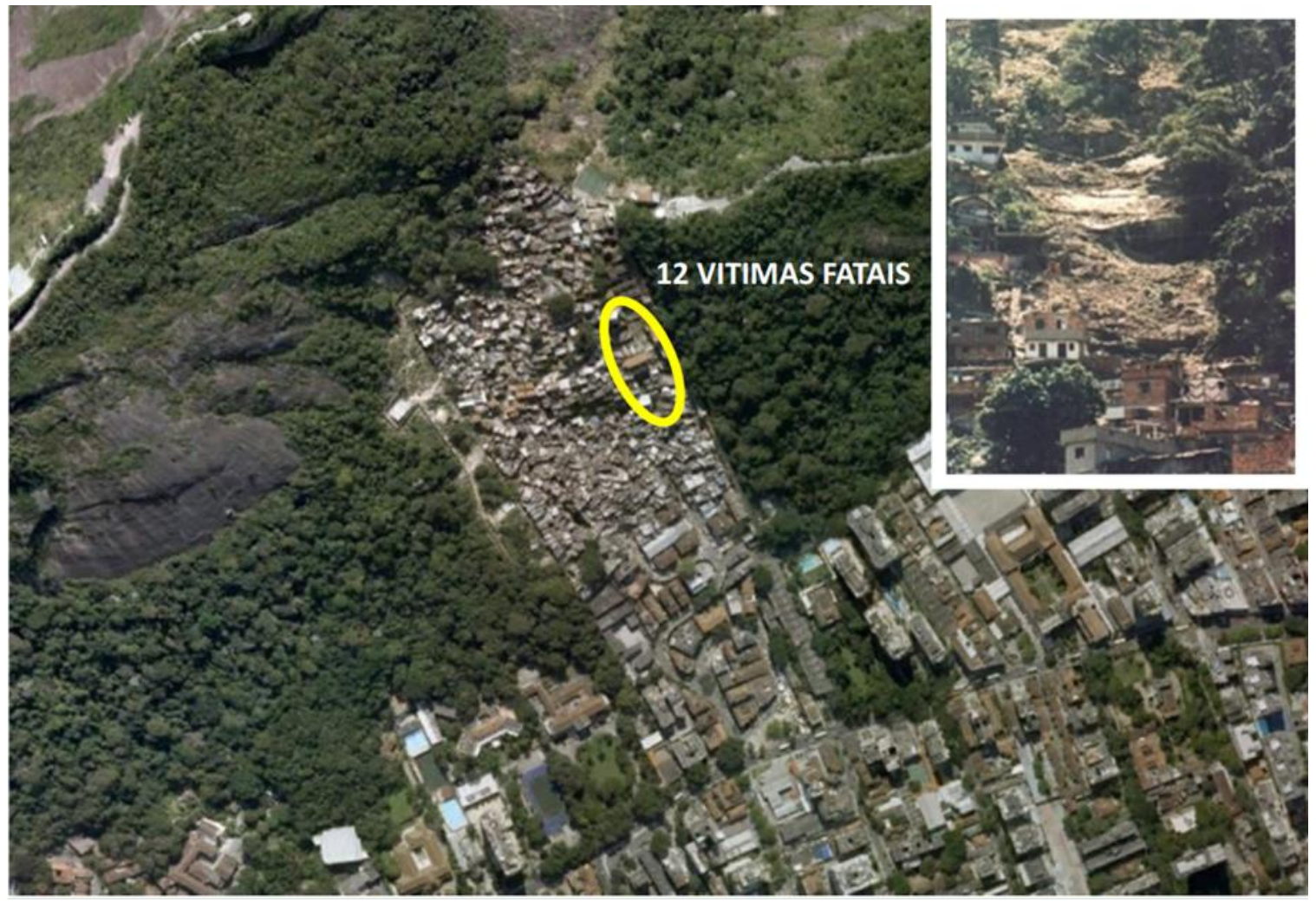

The top right photo from the GeoRio archive shows the February 14, 1988 landslide on a built over trash deposit in Santa Marta. The underlying google earth screen shot from 2012 shows where the landslide occurred. From GeoRio director Ricardo D'Orsi's presentation at the October 29 $9^{\text {th }}, 2013$ Panel "Are We Prepared For The Rains?". Hosted by the Rio de Janeiro State Society of Architects and Engineers.

In my archival research, I found several newspaper accounts of the 1988 landslide in Santa Marta. The mayor of Rio stated to the press that mitigations works had begun but were too late to prevent the landslide, primarily due to lack of funds. Residents were "disgusted" by the mayor and governor's lack of action, and announced that they were willing to protest in front of the prefecture and governor's office. Mayor Saturnino Braga told the press that he "recognized that the construction to contain the water on the top of the hill of Dona Marta are going very slow, and did not reach the locale where the landslide happened. Saturnino held the federal government responsible for the lack of 
funds to end landslides on the hillsides of Rio during the rainy season." 79 According to the mayor a survey was completed for all the areas where risk mitigation construction was needed, but the budget was too large for the prefecture consider. GeoRio had carried out a risk assessment in Santa Marta prior to the tragedy and was forewarned of the possibility of landslides that year when a GeoRio employee was killed in early January 1988 when a mitigation work collapsed due to heavy rainfall. There had been several new technologies for calculating risk that emerged since that event and Nelson gave an overview in that meeting.

Using a slide presentation projected on the wall, Nelson presented the criteria used for mapping risk gradiations using mathematical formulas calculated using incline, forest cover, and climate patterns. He began by presenting a slide on the "Concept of Geological Risk", which showed the equation R = P X C accompanied by the quote "Situation of danger[R, risk], loss or damage to people and their property [P, probability of losses], an event potentially caused by a geological process, induced or not [C, cause(s)]." This meant that GeoRio calculated risk by documenting physical features and then assessing the probability that it would occur. According to the calculations of GeoRio, risk was automatically increased by the presence of favelas. This was for two reasons. First according to GeoRio's epistemology, susceptibility was predicated on the presence of human settlements in the risk discourse. Second, they operated on the assumption that the vegetation had been burned or cut back during the process of settlement and that forests mitigated the risk of landslides. Nelson stated that landslide

\footnotetext{
${ }^{79}$ O Globo. January $27^{\text {th }}$, 1988. Page one. Deslizamento mata um e fere tres in Dona Marta.
} 
vulnerability does not occur in the absence of humans and showed in a slide that the boundaries of the favela were also the boundaries of "susceptibility" to geological risk. As Nelson used it in the presentation, susceptibility meant any probability of a risk event greater than zero. In the presentation, Nelson did not distinguish between risk, that is to say the probability of a harmful event to a specific population, and vulnerability, the exposure of that population to risk. ${ }^{80}$ In an alarming sequence, before showing the residents the different mapped levels of risk in Santa Marta, he included a slide that showed all of Santa Marta crudely covered by a bright red filter, which indicated high susceptibility to landslides in all areas of the favela (see Figure 5.3). He argued that landslides are natural processes, that can occur with or without human intervention and that risk exists independent of human perception, “we don't make these areas red [high risk areas], they are that way by nature", belying an epistemological approach based on a risk that inhered in nature rather than was produced by socio-ecological processes.

\footnotetext{
${ }^{80}$ For an extended explication of the difference between hazards, risk, and vulnerability see Grove, Kevin 2011. "Governing Social and Ecological Contingency through Disaster Management Policy and Practice in Jamaica" Doctoral Dissertation. Ohio State University. pgs 30-31.
} 
Figure 5.3: Map of susceptibility of landslides of Santa Marta and surrounding area.

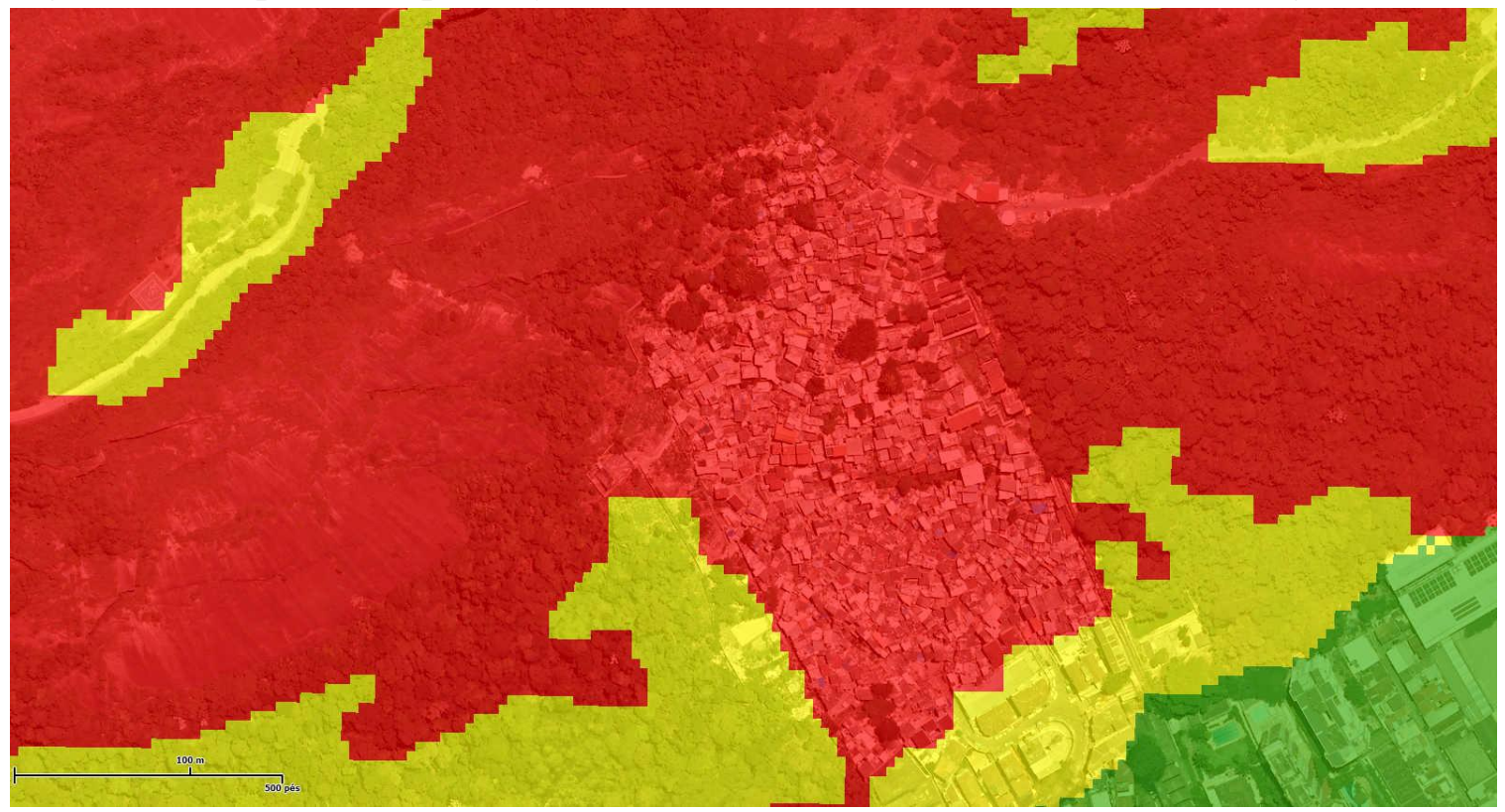

Red $=$ high susceptibility, yellow $=$ medium, green $=$ low .

Notice how the red filter follows the borders of the lower favela at right angles and shifts to medium risk where the architecture changes at the bottom of the favela. Image downloaded from PortalGeo, an interactive website resource of the Instituto Pereira Passos. http://portalgeo.rio.rj.gov.br, accessed June 07, 2013.

While at the beginning of his presentation he argued that he did not have a political agenda and that he was not there to convince or persuade anyone, he went on to reaffirm the credibility of GeoRio and used emotional analogies and techniques that were clearly intended to raise fear of risk and generate support for the state's project in Santa Marta. He presented the risk as an inert and neutral property that he was revealing to the residents through his presentation, and he had an "ethical obligation" that was above civil and national law to disclose the risk to them. In an attempt to relate this obligation to his audience, Nelson used an analogy of how parents understand risks that small children do not. He implied that, as a parental figure to the favela residents, Nelson's role was to both perceive danger that they could not understand and to protect them from this danger. He 
added the emotional example of a daycare in a risk zone, stating that any level of risk is too much when it comes to children, emphasizing that "every life is a life". By using these examples, he argued that the residents of Santa Marta's lives were in danger and that the function of GeoRio was to save lives. To fulfill this "ethical obligation" in Santa Marta, the prescription of GeoRio was to resettle the residents, reforest the area of the Peak and construct containment walls along the new border. This framing of the risk mitigation as the containment of geological risk and the restoration of the rainforest put Nelson in the dual role of protecting human life against 'nature' and restoring forest cover, which is a version of resilience biopolitics. Nelson's narrative on the nature of risk contradicted his earlier statement that it was GeoRio's job to mitigate risk whenever possible, and that they had successfully done so in Santa Marta previously.

\section{Three episodes of resident responses to risk discourse in Santa Marta}

\section{Episode One: The response to the GeoRio presentation}

"For years, we lived under the risk of a hail of bullets and now that things are getting better, the governor wants to remove us."

—Ze Roberto

"You are giving us options A, B, and C, but where is option D [resident proposals]?" 
Residents realized that the resettlement was the direct result of the risk mapping carried out by GeoRio, which legally reclassified the Peak as improper for occupation, and that the state was presenting them with preformed alterantives buttressed by that legal classification. The meeting environment in the UPP station was tense and there were many interruptions. Residents were familiar with the consequences of landslides but were confident that they lived in different conditions than those favelas that suffered landslides during the 2010 torrential rains or even the 1988 landslide in Santa Marta that had led to the activity of GeoRio in Santa Marta.

Aside from a large group of residents of the Peak, there were other activists and residents from the lower part of Santa Marta that attended the meeting that engaged Nelson directly by critiquing key aspects of his presentation. Sabrina, an activist resident who lived below the Peak, questioned why the technical expertise existed to secure buildings in other precarious areas of Rio, but not on the Peak of Santa Marta. She pointed out that no buildings on the Peak were affected by the landslide of 1988, only the lower portions now classified as "medium risk" had a history of landslides or building collapses. She further critiqued the description of the meeting as a dialogue, and argued that GeoRio and the Casa Civil were holding a monologue of previously made decisions, foreclosing the possibility that the residents could pose alternatives to the limited options presented to them. Resident participation, along with accurate information about resettlement programs and the right to housing, is required by the section of the Brazilian 
constitution that covers expropriation and resettlement, closely modeled on the UN right to housing (RioOnWatch 2016). ${ }^{81}$

Sinhô, who lived on the Peak, panned Nelson's argument that collapsed the risk mapping into the physical environment, especially when he stated that the risk was "natural" ${ }^{82}$ Nelson repeated throughout his presentation that the risk was a property of the Peak's geology, which he used interchangeably with "nature". Nelson explicitly argued that the different degrees of risk classification were rooted in natural processes, at the same time that he argued that while GeoRio was capable of mitigating risk in other areas of Santa Marta, it was impossible to make the Peak a safe place to live. In response to critiques by residents after the presentation, Nelson affirmed "the risk that exists" and argued that the Peak was at risk for geological reasons, even accounting for technical interventions, and argued that this condition foreclosed the possibility of mitigating the risk of the Peak. This argument conflicted with his earlier touting of GeoRio's past interventions to modify risk in Santa Marta in the areas below the Peak. Nelson stated that whenever it was possible, GeoRio kept residents in their homes by mitigating the risk.

\footnotetext{
${ }^{81}$ For a summary of the right to housing and adverse possession in Brazil and Rio more specifically, see this summary of Brazilian land rights law by RioOnWatch, a NGO that serves to raise awareness of favela issues and decrease the stigma attached to favelas. http://www.rioonwatch.org/?p=25334, accessed August $26^{\text {th }}, 2016$.

${ }^{82}$ GeoRio's 2011 assessment argued that human induced changes to the "slope" of the Peak since 2005 elevated the risk on the Peak (Contralaudo 2012). Human changes and the quality of building construction were a key factor in its risk calculations, meaning that favelas could be mapped as risk areas for settling on the hillside, and then as a result of that mapping, be banned from improving their homes, perpetuating the risk classification.
} 
When Sinhô also asked about the urbanization that they had been promised under a previous governor, Nelson responded that "the promised, owed construction is not sufficient to guarantee the safety" of the residents. In effect, he was confirming that the state had made a decision not to expand infrastructure to the Peak. This theme, the safety of the residents, cast Nelson and GeoRio as the final arbiters of governmental intervention in the Peak, defining the limits of public infrastructure and technical support for residences using risk assessments produced by GeoRio. Sinhô argued that Nelson and Ruth were "messing with our lives" and that for them the Peak residents were "guinea pigs", not to be respected. The guinea pig reference referred to continual and repeated framing of Santa Marta as the "model favela", where new programs for favelas were launched as experiments. ${ }^{83}$ Instead of urbanization improvements, Peak residents had been prohibited from improving their own homes, with the effect that they were made to live in the insecurity about their right to remain on the Peak.

Ze Roberto, Peak resident and construction worker, brought up the irony of governmental neglect and intervention on the Peak despite multiple state projects to "urbanize" Santa Marta. For years the residents of the Peak had been told that one day they would be 'urbanized' and that meant that the urban infrastructure would be expanded into the entirety of the favela. Ze Roberto recounted the previous promises of urbanization over the decades to the meeting organizers, telling how a pilot project prior to the UPP installation had transformed a dilapidated home in a risk area into one of the best homes in Santa Marta. This was what the Peak residents understood as urbanization-

\footnotetext{
${ }^{83}$ From a conversation with Sinhô following this meeting.
} 
as-improvement, while the current intervention had come to mean removal from the homes that they had built themselves, with foundations built on and into the rock of the Peak. The forced resettlement of the entire Peak of Santa Marta would be different from other urbanization interventions like the installation of the bondinho and the road access to the upper portion of Santa Marta, if carried out, the residents would be displaced from their homes and the history of the Peak would go with them. The new urbanization project represented a reconfiguration of Santa Marta as a space for favela life and threatened the sense of community of Peak residents as well as its history.

Ze Roberto related that his identity and his home were intertwined through the memories of adversity and celebration that he and his family had experienced there. "You can all go back to your homes after you are done here, it is easy to say that we must leave" he cogently argued. Ze Roberto further pointed out that moving to the tiny apartments of the project housing would be a cultural shock and loss of privacy for some residents that had homes more than four times as large. Ze Roberto then asked if Eike Batista, the richest man in Brazil at that time, would be allowed to construct a hotel above Santa Marta after the Peak was removed, as Batista had done in the favela Vidigal. ${ }^{84}$ Vidigal, a much more gentrified favela, had similar geography to Santa Marta. Ruth maintained that the state would not allow private construction on the Peak of Santa Marta, but residents remained incredulous. Resident activists in Santa Marta were cognizant that Vidigal had been threatened with removal en masse during the dictatorship and it was later disclosed that the government had ceded the land to a development firm

\footnotetext{
${ }^{84}$ See chapter three on the attempt to displace the favela Vidigal in order to construct a luxury hotel.
} 
to build a luxury hotel (McCann, 2). The removal of Vidigal was interrupted by legal activists that used adverse possession laws to avert the displacement. ${ }^{85}$ In Santa Marta's situation, the high risk classification barred the Peak residents from using the same adverse possession strategy, which had been strengthened by the 1988 constitution. In a shift in tactics, the Peak residents contested the risk classification to be able assert their legal rights, which I discuss later in this chapter.

Ze Roberto observed that when the state wanted to construct buildings in Santa Marta in a risk area, they drilled the foundation into the rock, proving that it was possible to construct in risk areas. He added that the 1988 landslide in Santa Marta and the recent landslide in Niteroi occurred because of construction over landfill areas, while the Peak residents had built their homes into the rock of the favela. Another resident interjected that the project housing was being constructed in the location of an old landfill, exactly the condition that had led to the tragedy in 1988 . Nelson countered that the greatest danger to the Peak came from the rock above, but the residents argued that rockslides only occurred to the west of the favela, under the escarpment of the Tijuca massif. For the Peak residents, the risk issue was a technical problem, but not one that eliminated options, rather one that could be overcome with the application of techniques.

Nelson responded to the residents' questions by reasserting that his methodology closed the discussion on the risk evaluation and he denied that GeoRio had a political or economic agenda. At this point, Nelson shifted to argue that cost was a factor, stating that "high complexity of the construction, the extremely high cost of construction, that

\footnotetext{
85 The NGO Bento Rubiao
} 
still wouldn't one hundred percent guarantee the security of the residents". This statement was hyperbolic, as Nelson was well aware of the impossibility of eliminating risk completely. Many residents of the Peak remained unconvinced by this argument, there was no way to provide absolute certainty of the absence of socio-environmental risk in Santa Marta, but disaster and flood risk was pervasively present throughout Rio. The Peak residents had managed without complete infrastructure for decades, and now that there had been improvements in the conditions in the favela below, the expansion of public services was being withheld to discipline the residents into resettling to the project housing.

Nelson concluded his presentation by confirming that after the resettlement program was implemented, the state would reforest the Peak and construct containment walls to protect the favela below. He further contended that the information presented that day was the final analysis of risk. But that was not to be the case. When Ruth attempted to close the meeting, the residents revealed that they had requested a contralaudo (counter assessment) of the risk in Santa Marta with the aid of an activist and civil engineer named Mauricio Campos ${ }^{86}$ Ruth said that they would reconvene when they had received a copy of the contralaudo and had evaluated it. Thus, the announcement of the contralaudo's existence served to disrupt the resettlement process.

\footnotetext{
${ }^{86}$ Mauricio Campos belongs to an NGO called Rede Contra Violencia (Network Against Violence). He had previously carried out counter assessments in other favelas from 2010-2011, including Providencia near the downtown zone and prefecture buildings, Tabajaras in Botafogo, Morro dos Prazeres/Escondinho in the bohemian Santa Teresa neighborhood. Conversation with Mauricio Campos after the Hike Against Removals event on Sept $2^{\text {nd }}, 2012$.
} 


\section{Episode Two: The contralaudo presentation in Santa Marta}

On July $25^{\text {th }}, 2012$, I attended a meeting that was held to present the results of contralaudo to the Peak residents, produced by Mauricio Campos. ${ }^{87}$ On invitation from the Peak Committee, Mauricio had carried out an onsite inspection on February $27^{\text {th }}$, 2012, a little more than a month after the general assembly meeting presented in chapter four (Campos 2012). Mauricio used his onsite inspection to evaluated the risk assessment produced by GeoRio on January $3^{\text {rd }}, 2011$ and produce the contralaudo (Campos 2012). The meeting to present the contralaudo was held in the evening in a small open building near the fifth tram station used to commemorate events in Santa Marta, such as birthdays. The presentation was scheduled to maximize participation for Peak residents returning home from work. I was invited by Sinhô who said I was welcome to attend, but advised that I keep silent to avoid introducing any tension between different activists. The presentation of the contralaudo brought anti-displacement activists from outside Santa Marta together with the Peak Committee. I was forwarded a copy of the contralaudo prior to the meeting and had discussed it with my research contacts in Santa Marta beforehand. I was the only researcher who attended, but several activists from lower Santa Marta, including Itamar Silva, and one activist from Tabajaras attended. Accompanying Mauricio Campos was a member of Bento Rubião, the Catholic legal assistance organization that helped favela Vidigal residents resist displacement in the 1970s. Bento Rubião had recently been active during the attempted displacement of the favela Laboratorio, which straddles the upper reaches of Rocinha and the wealthy neighborhood

\footnotetext{
${ }^{87}$ My fieldnotes from my attendance of that meeting.
} 
Gavea in Rio near Lagoa. Laboriaux's risk situation was very similar to the Peak's, as it was located at the top of a hill that was adjacent to a nearby wealthy neighborhood.

The contralaudo's preliminary assessment undermined a central argument used by Nelson in the GeoRio meeting, which was that the Peak was at a higher risk than the rest of Santa Marta from landslides originating above the Peak. A landslide that originated above the Peak, especially one consisting of falling boulders, according to Mauricio's contralaudo, would pass through the Peak and impact the rest of Santa Marta. The mapping of the Peak as a high risk area had divided the favela in two groups, but the contralaudo's finding that the alleged threat of a rockslide would impact all of Santa Marta brought the Peak's fate together with the rest of Santa Marta. Another key finding of the contralaudo was that the GeoRio assessment had ignored some of the significant infrastructure improvements that had already reduced landslide risk within the favela. The most salient of these was the water canalization system that routed water runoff from above to the western side of the favela into the surrounding forest. Mauricio argued that these infrastructure improvements had substantially reduced the risk of living in Santa Marta and that with maintenance they would continue to do so. The contralaudo also undermined the fiscal argument made by the Casa Civil and GeoRio, without divulging specific calculations, that efforts to mitigate the risk would cost more than resettling the residents. Mauricio argued that with the pre-existing mitigation works in place, the additional mitigation construction would be cheaper than resettlement. Mauricio added that according to the 'risk from above' argument used by GeoRio, "the stabilization of 
the hillside adjacent to the Dona Marta Viewpoint would continue to be necessary, even if there was a total removal of the Peak (Campos 2012)." 88

\section{Episode Three: The Hike Against Removals}

After the contralaudo presentation, Mauricio and Itamar suggested that the Peak residents organize an event to raise consciousness of the Peak's struggle to remain in its historical location, where Peak activists would organize participants to hike to the Dona Marta Viewpoint from the bottom of the favela. I attended an organization meeting that was held several weeks later, to discuss the dates and name of the event, where the attendees decided to call the event "Trilha Contra Remoção" or Hike Against Removals. On, September $2^{\text {nd }}, 2012$, the Hike Against Removals event brought more than forty participants to the Dona Marta Viewpoint after the initial concentração or meet up at the base of the favela in the Praça Corumbá on São Clemente street. ${ }^{89}$ Before hiking through the narrow and winding alleys and paths up to the same community center on the Peak where the contralaudo meeting took place, the itinerary was announced and participants made signs with materials brought from home. The first leg of the hike was attended mostly by a group of twenty outsiders, including myself, activists from nearby favelas, Mauricio Campos, several Brazilian researchers, along with a handful of residents from lower Santa Marta. At the Peak, just below the fifth tram station and the UPP headquarters, two key activists, one from the Peak and one from lower Santa Marta spoke

\footnotetext{
${ }^{88}$ Mauricio was not given access to all of the documents used to make the GeoRio assessment, only the Field Summary provided by Concremat, the private firm that was contracted by the prefecture to carry out the assessment under the direction of GeoRio, using GeoRio data and LIDAR from a helicopter. Fieldnotes from the Contralaudo meeting.

${ }^{89}$ Fieldnotes from my attendance of this event on September $2^{\text {nd }}, 2012$.
} 
to a group of around 40 people during the "conscientização" or awareness raising leg of the event.

The two speakers, Sinhô and Itamar, contested the mapping of the Peak as a risk area and reminded the audience that the state had already demonstrated that risk areas could be reclaimed with the appropriate construction techniques. Sinhô held a sign criticizing the imperious implementation of public policy in favelas and Itamar held one that said "Santa Marta, model of what?". For Sinhô, the plan to resettle the Peak was another in a series of state actions that failed to take account of the livelihoods of Santa Marta residents and showed that the state lacked the political will to improve the living conditions of Santa Marta's most vulnerable residents. Itamar called for solidarity by emphasizing that the Peak was a valued part of Santa Marta and that the struggle to remain was important for all of Santa Marta. Itamar told the hike participants "There are not two favelas here, one above and one below, only one favela exists." Itamar further recalled the Peak's importance as an origin site for the beginning of Santa Marta. Itamar, who worked as an editor for an environmental justice NGO, had contributed to a book published in 2011 on the history of Santa Marta that described the Peak as one of, if not the first, founding sites for the favela in the 1930s (Silva 2011). For Itamar and the Peak residents, the resettlement of the Peak represented a rupture in the history of Santa Marta as well as an arbitrary division of the favela into habitable and "inappropriate for settlement" territories. 
After attending the conscientizacao, I hiked the trail above Santa Marta up to the summit of Dona Marta hill with a smaller group to the tourist viewpoint. ${ }^{90}$ The trail was known to residents, but rarely used, so Peak residents pointed out handholds and better footing as we climbed. One of Santa Marta's oldest residents who moved to Santa Marta in the mid-1950s from northeastern Brazil, accompanied the group and pointed out the locations of homes that had been displaced in the 1970s along the trail (see chapter three). Marco told of a more rural lifestyle with livestock in that period and how the residents used a nearby spring for water. Many of the attendees of this event were not aware that part of Santa Marta had already been removed, so the event became more than a protest, it was what Brazilians called a recuperação or recovery of the history of Santa Marta.

\section{Counterdiscourses in the Disaster Risk Reduction (DRR) assemblage}

In this section I use an analytics of assemblage to describe how residents of Santa Marta responded to their articulation with the DRR discourse and the resettlement project. Before I engage with the particularities of resident responses, I provide a brief overview of the discourses articulated within the assemblage of DRR. As I wrote in chapter two, a genealogical approach holds that power is productive and that it circulates within the dispositif, or assemblage. As Braun writes, the exercise of biopolitical power is lively, it changes according to contingency and emergence (Braun 2014). The emergence of new discourses enables their articulation with already existing elements of the assemblage and new forms of governmental practices. In the case of DRR in Rio,

\footnotetext{
${ }^{90}$ See chapter three for a history of the reformation of the viewpoint and the creation of the Tijuca National Park.
} 
vulnerability mapping and risk discourse emerged in the 1980s and superimposed risk mitigation onto disaster preparedness practices, a process that was repeated throughout the developing world in the 1990s (Grove 2013a). The addition of risk mitigation to preparedness marks the shift to resilience discourse, and scholars critical of resilience discourse have identified de-politization as one of its harmful effects (B. Evans and Reid 2014; Grove 2013c; Grove 2014b; MacKinnon and Derickson 2013). In the case of DRR discourse, risk mapping is the primary biopolitical technique with depolitizing effects, and risk mapping is precisely the element of the DRR assemblage that the residents of Santa Marta have responded to and mobilized counterdiscourses against. Even though the residents of Santa Marta are articulated with the DRR assemblage, points of friction emerged within that assemblage at the loci of depolitization effects. Understood through the genealogical approach, Santa Marta residents opened up a space for the reactivation of politics by critiquing the contradictions of the DRR/Morar Seguro resettlement program in Santa Marta (Grove 2013a). Furthermore, they mobilized counterdiscourses as a political strategy to retain their right to place and remain on the Peak, a place that had shaped their identities as a community within Santa Marta. In the remainder of this chapter, I will construct a provisional typology of those counterdiscourses according to the different purposes and tactics they used.

Soon after the state divulged its plan to resettle the peak, residents began mobilizing counterdiscourses, the most prominent example was Itamar's letter to president Lula in 2009, which I discussed in chapter four. When the state began urbanization meetings in Santa Marta in 2011, residents responded within those same meetings with critiques of the urbanization and resettlement project, critiques prepared in 
community meetings for residents concerned by the resettlement plans. I call those critiques, practices and techniques used by Santa Marta residents to reactivate community politics counterdiscourses. I identify three contradictions that are key to understanding the counterdiscourses I elaborate upon below, which I have discussed in previous chapters in detail. First, the state of Rio used Santa Marta as a model to promote its favela program, but residents critique the incomplete urbanization of the favela and the neglect of their rights as Brazilian citizens. Specifically, residents of Santa Marta find that the right to housing that should protect decades old settlements has been hollowed out and quality of the infrastructure that does exist is far from exemplary. Second, urbanization was framed as improvement by the state when promoting the investment in Santa Marta, but the state urbanization plan for the Peak represents displacement and the loss of the Peak residents' community identity. Third, the state uses area of risk as if it was a permanent quality of Rio's urban geography, but previous state interventions in Santa Marta used technical expertise to mitigate that risk and construct in places formerly mapped as risk areas. These contradictions were noticed by the residents and formed the basis of the critiques mobilized in the urbanization meetings. Residents summed up these contradictions with a sign used in early protest event for a governor's visit in 2009: "Dear Governor, the top part of the model favela is not a risk area, but it is abandoned by the state. We don't want to be removed from our houses, but we do want improvements like urbanization." 91

\footnotetext{
${ }^{91}$ Sinhô 's facebook photo from 2009.
} 
I group the resident critiques and corresponding practices into four types of counterdiscourses to the resilience biopolitics at work in Santa Marta in the form of DRR discourse: Historical, Visual, Participation and Technical. In the following, I explicate each in turn.

Historical counterdiscourse is the situated knowledge of the history of Santa Marta, that is to say resident knowledge of previous landslide events and the different iterations of risk mapping by the state. This historical knowledge enabled critiques of naturalized risk claims by the state of Rio. The state of Rio has an "Inventory of Risk" that is a record of GeoRio's history of events in favelas beginning in 1986. In the urbanization meetings, residents use their collective memory of events prior to 1986 like the removal in the 1970s to show that the state's record was incomplete. In response to the state's claim that construction in risk areas was not feasible, the Santa Marta residents put forward their own historical knowledge to argue that construction was possible in risk areas that had changed along with state mitigation calculations and mapping techniques. Specifically they pointed out that the previous resettlement intervention that accompanied the tram construction had located the new buildings in a previous risk area after the 1988 landslide in Santa Marta and that the site of the most recent resettlement project used to be a landfill before the urbanization intervention in the 1980s. Cogently, Santa Marta's residents repeatedly pointed out that the Peak had never experienced landslides, but landslides had previously occurred where the state constructed project housing in the 1990s. Residents used this historical discourse to disrupt the agenda of urbanization meetings and redirect Urbaniza employees to the risk justification. 
Visual counterdiscourse is the practice of increasing the visibility of community politics and the critiques of the resettlement project in Santa Marta. Residents acted to increase the visibility of their contestation of the resettlement project. They raised awareness of the threat of displacement by organizing events in Santa Marta, and mobilized anti-risk area narratives to promote solidarity with the Peak among favela residents and outside activists. This visibility counterdiscourse allowed Peak residents to articulate with key figures outside Santa Marta that provided assistance for the technical counterdiscourse described below. Residents took advantage of the people circulating through Santa Marta and the Peak by putting flyers on their homes with anti-removal slogans. Their homes were right in front of the fifth tram station's viewpoint, which was visited by thousands of tourists each month, including members of the media, and notable figures such as the head of the United Nations and Vice President Joe Biden. These slogans included "Favela, model of what", "No to removals!", and "Where is the urbanization?".

Participation counterdiscourse includes the critiques of the way meetings were conducted and the resettlement project was planned, especially regarding resident participation and input into the planning of the resettlement project. Residents repeatedly critiqued the project for failing to account for resident input, which was a requirement for such a project according to the right to housing in Brazilian law. From the beginning, residents critiqued the delay in the urbanization project at the general assembly for neglecting Santa Marta when it was ostensibly the model favela for Rio's favela programs. I think this delay undermined the urgency argument for the resettlement of the Peak, the state mapped the Peak as a high risk for landslides, but put it at the back of the 
line for the beginning of Santa Marta's urbanization intervention. Several favelas near the downtown zone of Rio were entirely removed in 2010 and 2011, and urbanization projects began in Babilonia and Cantagalo before Santa Marta. Furthermore, one former state employee told me that it was a mistake to announce to the Peak that everyone would be resettled before the actual buildings for the resettlement were constructed. ${ }^{92}$ As Urbaniza's survey team visited each resident, they performed initial evaluations of the quality of their home that would leave them no option but to move to the resettlement project housing. Doing so left Peak residents in a state of prolonged insecurity about where they would live and if they would be able to adjust to life in the new project buildings.

Technical counterdiscourse is an alternative expert evaluation or assessment that contests the technical discourse of the state or non-governmental organization. Lawyers are an example of a type of specialist that have helped with counterdiscourses to contest favela removals in the history of Rio (Gay 1994; Fischer 2008; McCann 2014). In this research, the counterdiscourse emerged when a specialist intervened to disrupt the episteme of the biopolitical technology of risk mapping by producing the contralaudo or counterassessment. The contralaudo acted to contest the state's risk mapping and reactivate the land rights of Santa Marta residents. The same engineer produced contralaudos to contest risk removals for several favelas, including Providencia and Morro dos Prazeres/Escondinho.

\footnotetext{
${ }^{92}$ Interview with Urbaniza employee July 1, 2012. I communicated this to the Peak committee in a meeting held prior to the GeoRio presentation.
} 


\section{Conclusion}

In defending their place and identities, the peak residents used counterdiscourses to contest the biopolitics of the DRR resettlement program. Rather than the "hidden transcript" that Grove (2013) used to elucidate resident struggles against resilience biopolitics, the counterdiscourses of the Peak residents were publicly made both within and outside of state institutions, similar to what James Scott (1990) called a "public transcript" but without the expectation that the oppressed will acquiesce in confrontation with the state (Grove 2013c). In fact, the effectiveness of residents' counterdiscourses depended on high visibility in many cases. In terms of assemblage thinking, counterdiscourses are not external or in opposition to the DRR assemblage enacted in Santa Marta, rather the point of friction is between the forces of depoliticization embodied in the resettlement intervention and community politics of place within the DRR assemblage. Counterdiscourses are articulated to the assemblage simultaneously as they open up new spaces for activating politics.

This chapter is a response to critiques of the green governmentality literature that called for greater attention "to the ways in which governing is always becoming, necessarily uneven, often contested, and sometimes exercised outside of the state" (S. Rutherford 2007, 292). I carry this critique further to biopolitical approaches by writing on the ways that residents activated their politics in the biopolitical program of DRR in Santa Marta. As Grove writes, biopolitics is not actualized evenly, it often targets micropopulations (Grove 2014b, 611). This chapter also speaks to critiques of the resilience discourse that point to the depoliticizing effects of biopolitics in resilience programs, in 
this case DRR (B. Evans and Reid 2014; Grove 2014b; MacKinnon and Derickson 2013). The DRR programming from Rio's urban resilience strategy was generative of community politics, albeit one that contested the implementation of DRR programming. 


\section{Conclusion}

My research informs broad debates on the sustainability of global urbanization, the role of international institutions and the state in managing disaster risk, and the participation by residents of informal settlements in urban policy implementation. Using a biopolitics assemblage analytic assembled from the green governmentality and critical disaster risk literatures, this dissertation demonstrates that the project of disaster risk reduction in Santa Marta was implemented without accounting fully for resident participation and that the calculation of high risk areas can be a highly politicized project. The resettlement program in Santa Marta took on extra significance in Rio because of its framing as the model favela for government programs for favelas throughout Rio, and since the government of Rio presents itself as a model for cities in other developing countries through venues like the $\mathrm{C} 40$ organization of global cities. I found the use of both Santa Marta and the city of Rio to be problematic. The tens of thousands of poor residents displaced in the lead up to the 2016 Olympics hearkens back to the favela displacements of the 1960s and 1970s dictatorship in Brazil. Thousands of favela residents were resettled under the area of risk rationalization and calculation, undermining the right to housing in the 1988 Brazilian constitution, which drew heavily on United Nations principles. There are United Nations guidelines for resettling residents of high risk areas, even as the United Nations participates in disaster risk reduction programming for the developing world. How those programs are carried out will impact the lives of millions of people in the global south. The right to housing is important in 
areas of the world where incomes are low and housing stock is insufficient, like Rio de Janeiro, Brazil. I will now turn to the scholarly contributions of this dissertation.

This research has made four broad contributions to scholarship. The first is the political ecology of informal urban settlements, which has only recently emerged in the literature. In the past, political ecology examined the contradictions and faulty assumptions of development schemes that targeted rural poverty by researching their historical, cultural, and spatial geographies. Now many of the poor in the global south are moving to cities, primarily to urban informal settlements. This research has taken a theoretical approach from political ecology in green governmentality and examined its limits for the analysis of disaster risk reduction interventions in informal urban settlements. This dissertation adds a new analysis of "displacement beyond gentrification" of informal urbanity, that is to say state directed displacement beyond the raising of rents, a topic that has seen increased attention in places like India and South Africa, but rarely in post 1980s Latin America (Roy 2005; Huchzermeyer and Karam 2006; Koonings and Kruijt 2007; Varley 2013; Ghertner 2014; Janoschka and Sequera 2016). Political ecology has paid close attention to displacement of the poor and the relationship of displacement to the creation of protected areas. This research adds a focus on protected areas and informal settlements to the interdisciplinary displacement literature in the Global South. The scholarship on protected areas has rarely addressed protected areas in or near cities, a socio-environmental conflict that is likely to become more frequent if urban areas continue to expand at rapid rates, and this research has addressed the lacunas of these three different domains within Political Ecology, that is to 
say displacement from urban development projects, green governmentality and the biopolitics of disasters.

The second contribution is in critical disaster studies, a field that has been reconfigured from scholarship on the politics of disasters and the socioeconomic roots of hazards (Pelling and Dill 2010; Peet and Watts 1996), and is emerging as expanding scholarship links climate change to the increased frequency and intensity of disasters (Grove 2013b; Grove 2014a; Brown 2014). While this dissertation doesn't contest that relationship, the increased focus on climate change induced disasters has mobilized an array of state and NGO interventions to reduce disaster risk through the discourse of resilience. My research topic here is indirectly linked to climate change and therefore resilience, since DRR maps high risk areas in part by calculating how increased rainfall induced by climate change has increased frequency of landslides as effects. ${ }^{93}$ These interventions are mediated by culture and power relations, which shape how these interventions are carried out and the concomitant uneven effects on the social. Critical disaster research is expanding to interrogate the assumptions and unintended consequences of resilience thinking as that discourse has become dominant in the emerging Anthropocene. The de-politicization of informal urban settlements targeted for resettlement by DRR interventions looms large among the effects of resilience discourse, in other words resilience discourse acts to make informal settlements into the inert targets of biopolitical schemes to improve or displace at risk populations, and this dissertation

\footnotetext{
${ }^{93}$ The city and state of Rio have already included rainfall measurement in their calculations for landslide risk and have installed a network of rainfall measurement devices throughout the city of Rio to differentiate that risk. See Prefecture of Rio de Janeiro 2015. Rio Resiliente: Diagnostico e Areas de Foco. Municipal Document.
} 
has shown how those targeted by DRR interventions have mobilized a politics of place in response.

The third contribution is a deepening of the biopolitics literature into the urban and disaster domains of human geography. I argued in this dissertation that the techniques of calculating disaster risk since 2008 constitute an emerging biopolitics of favela management that simultaneously seeks to reduce the risk of landslides, shrink the territory of favelas, and expand forest cover in Rio's urban rainforest. Biopolitics has recently become an expanding approach in human geography for analyzing how populations are governed through risk calculation and the politics of improving populations deemed to be a threat or threatened by risk, as I showed in chapter two. My research adds a focus on how biopower is exercised on embodied subjects, how those subjects are differentiated from informal urban populations through the process of rendering technical, and how populations rendered technical by biopolitical programs can mobilize counter-discursive practices that reject the rationalization underpinning intervention discourses from within the intervening assemblage. In doing so, I contribute to the wider interdisciplinary research using a Foucaultian biopolitics analytic and employing archival and ethnographic methods. In particular, I add to the literature in human geography on urban and disaster biopolitics, detailed in chapter two.

The fourth contribution is at the intersection of Political Ecology and Science and Technology Studies (STS). Literature at this intersection examines scientific practice as cultural and social practice embodied in particular places and relations of power that shape the emergence of scientific disciplines and their application in specific contexts 
(Forsyth 2003; Mara Goldman, Nadasdy, and Turner 2011; Lave 2012; Lave 2015).

Work at the intersection of Political Ecology and STS has critically examined the participatory requirements of development projects that frequently deploy scientists to carry out environmental impact assessments and disaster risk assessments, with my research contributing to the latter. My research situates the science enrolled to rationalize the calculation of disaster risk in the cultural and political context of the site of the biopolitical intervention, while also calling attention to the political responses of those threatened by displacement through disaster risk reduction programs. Furthermore, research at this intersection critically examines how different meanings and constructions of nature are mobilized for political and development projects. In chapter five I show that the municipal geologist brought to the favela Santa Marta to present the state's argument for the high risk assessment collapsed the risk of landslide into the "nature" of the hill the favela was settled on and did not distinguish between risk and vulnerability, even though an examination of that institution's own risk assessment documentation shows that anthropogenic change to the landscape — in terms of infrastructure, building quality, and forest cover - was a major criteria for calculating landslide risk on the hillsides of Rio de Janeiro. ${ }^{94}$

I examined the themes of favela displacement, reforestation as a mitigation technique, and risk calculation and found that disaster risk became the dominant form of favela displacement in the 1980s, after favela removals had ostensibly ended as official state policy. By critically examining the risk communication process, I found that the

\footnotetext{
${ }^{94}$ See (Carse 2014) for an example of the STS literature that examines the political ecology of infrastructure and the meanings of nature.
} 
state enrolled geologists and engineers for their authoritative effect, even while neglecting the transparency that a scientific endeavor should have. In the resettlement process, this led to pro forma resident participation where the state held meetings to tell residents what was about to happen to them, rather than consulting residents for their views on how their community should be improved. Residents' collective memories showed the state was capable of risk mitigation in Santa Marta when it was willing to expend the resources, and that the state's policy was to move favela residents to resettlement housing, even if it meant constructing on former risk areas.

Historically, the state has constrained the improvement of hillside favelas by making them illegal or legally prohibiting the upgrading of buildings and infrastructure in favelas. This prohibition was relaxed somewhat in the 1980s and 1990s, but the 2000s brought new state programs that acted to prevent favela residents from upgrading and expanding their homes, aside from already existing prohibitions on favela settlement expansions. I refer to the effects of these prohibitions as the "geography of precarity". By effects, I mean the differentiated levels of infrastructure provision and quality of building construction in favelas and between favelas and other urban neighborhoods. The dominant political technology for controlling favela space was the notion of "area of risk" that limits where and what type of infrastructure the state will construct, in addition to delimiting the space that is "appropriate for occupation". According to my archival research, area of risk emerged in Rio after a World Bank financed disaster response project in the late 1980s. 
Area of risk is a spatial representation of risk mapping for landslides and floods in Rio. Risk mapping, as performed by municipal employees of GeoRio, accounts for anthropogenic change, meaning that the high risk areas mapped onto favelas throughout the city of Rio are calculated using criteria that include forest cover, infrastructure provision, and the condition of the homes that favela residents construct themselves. These criteria are problematic since nearly all favelas in Rio are built on forested hillsides and the condition of favela residences is constrained by laws forbidding improvement to houses in favelas. Furthermore, GeoRio did not completely disclose the anthropogenic basis for risk mapping, and stated to residents that risk mapping was a natural property of the physical geography of the hill on which Santa Marta was settled. Residents recalled that risk mapping had changed the location of risk within the favela Santa Marta since 2009, revealing that sociotechnical factors modified the risk evaluation. The exacerbated unevenness of infrastructure provision within favelas and between favelas and the rest of Rio from risk mapping has worsened Rio's geography of precarity. While Santa Marta had significantly more infrastructure improvements than most favelas outside of the wealthy southern zone of Rio - including a health center, a partial sewage system, and WIFI internet - its characterization as a "model" for favelas in general was limited by its particular geography, size and history of infrastructural improvements.

During my field research, I observed a pattern of the state neglecting resident input into state projects that ostensibly were not public security issues. While the state of Rio did not announce the plan to displace Peak residents and reforest the Peak until 2008, urban planning documents from 2004 show that the resettlement of the Peak was a priority of the state of Rio from the beginning of the urbanization project carried out from 
2004 to 2008, despite resident participation in urban planning dialogues with the state before 2004. Resident participation, in the form of requests for access points to the forest and a lower wall, was further ignored with the construction of the ecobarrier in 2009 that walled off the favela from the forest to the west. Residents told me that the ecobarrier did not serve the purpose of delimiting Santa Marta from the surrounding forest, instead the infrastructure improvement in the form of a canal system built after the 1988 landslide delimited favela space in Santa Marta, which grew vertically by adding new additions to homes rather than horizontally across the landscape. After analyzing previous government statements made when a wall was proposed to be built around the favela Rocinha in the mid-2000s, I suggest that the ecobarrier served two purposes. First, to show that the government was doing something substantial about "the favela problem", recently highlighted by satellite studies of favela expansion, which according the state's narrative included environmental degradation in the form of deforestation. Second, the wall served a function for the UPP to prevent the re-entry en-mass of armed drug traffickers, the dreaded "invasão". The wall made it easier for the UPP to control access points into and out of the favela, where they frequently searched people for drugs, although by the time I had arrived in 2011 there were holes in the ecobarrier large enough for a person to pass through into the surrounding forest.

The versions of governmentality that emphasized decentralized control and responsibilization did not find much friction on a state driven resettlement project for high risk areas. The effort to produce new urban subjects in favelas could be approached using governmentality in this sense, but the state refused to provide state services in high risk areas and promoted resettlement to government project apartments. Furthermore, the 
Peak residents' disruption of the resettlement process hindered the effort to produce new urban subjects to the extent that it slowed down the resettlement process. Arguably, many Peak residents refused to be governed by a discourse of urban subjects that required resettlement in government project housing, a project permeated with the DRR discourse. To refuse that version of urbanization, residents organized in anticipation of the resettlement intervention, which was informed by their previous experiences with government project housing in Santa Marta and in neighboring favelas. In response, residents contested the risk mapping of their community founded in the 1930s and mobilized counterdiscourses, including an independent counter assessment of risk.

The generalizability of this research to other favelas or cities of Rio has a number of limitations that I will detail here. As a favela in a higher income area of Rio de Janeiro with access to greater levels of state services, Santa Marta has more infrastructure than most favelas throughout the Rio metro area. It is located in the South Zone of Rio, which has a high level of tourism, police presence, and is therefore frequently visited by researchers from Brazil and abroad. Residents in Santa Marta were accustomed to interaction with the state and urban improvement interventions, many favelas that are resettled have had little to no support from the state in terms of infrastructure improvements. I focused my research on a particular group within Santa Marta that is important for its history and with a place based identity that is differentiated from Santa Marta as a whole. This of course means that I cannot infer general conclusions from the Peak residents to the rest of Santa Marta or other favelas. However, since I traced discourses from Santa Marta to other scales of government historically and during my field research, this research is relevant for the programs permeated by discourses like 
disaster risk. The UPP and DRR programs were produced by a particular alignment of municipal, state, and federal governments flush with cash from the 2000s commodity boom. The resettlement program in Santa Marta was carried out by the state of Rio, where most resettlement displacements in Rio were done by the prefecture of Rio, meaning there are disconnects between the state and municipal programs for favelas. Rio is a relatively wealthy urban area under scrutiny by the global media, as well as being the location of the headquarters of United Nations Habitat. This puts constraints on the ability of the state to ignore laws that protect land use rights and United Nations guidelines for resettlement than in informal urban settlements in other parts of Latin America. Furthermore, since Santa Marta was used as a "model" for favela policies by the state, the discrepancies and consistencies between Santa Marta and other favelas is important for understanding the differentiated effects of DRR and the UPP program in the favelas of Rio.

\section{Prologue}

Since I ended my field work, a number of important events have occurred. Brazil's federal government is in a fiscal crisis and President Temer supports widespread austerity measures to address the federal fiscal crisis. President Temer has lost six ministers to corruption charges in as many months, after President Roussef was impeached for budget irregularities. Since the Olympics, the state of Rio has declared a state of fiscal emergency, halting construction on the project housing used to resettle favela residents and was forced to ask for federal funding for the state budget. Budget shortfalls threaten the continuation of the UPP program in Rio and ended the payment of 
social rent for residents evicted for government construction projects. Residents of the favela Babilonia, who were evicted from their homes for onsite construction of resettlement housing and given rental assistance payments to await ongoing construction, were told that they were to be resettled to the west zone of Rio because the third and fourth buildings that were promised for resettlement within the favela had been indefinitely postponed due to the fiscal situation.

The favela Vila Autódromo was nearly entirely removed in 2015 for the 2016 Olympics construction, a parking lot and part of the Olympic village, despite having a use rights agreement with the state of Rio for 99 years. This eviction was initially justified by the area of risk rationale since the favela was adjacent to a lake and this presented the potential for flooding. Later the prefecture used heavy handed tactics including intimidation, cutting off road access to the community, and dividing residents with buyout offers. Since the Olympics, the prefecture has made it known that area will become a high rise development zone. In 2016, O Globo reported that the firm Concremat, contracted to carry out the technical portion of the risk mapping in Rio's favelas, was part of the consortium for Olympics construction involved in the ongoing corruption scandal in Rio. Governor Sergio Cabral, who was a major proponent the UPP program, Morar Seguro and the construction of the tram in Santa Marta, has been indicted for corruption schemes related to construction for the World Cup and Olympics.

In Santa Marta, the tourism program designed to increase resident incomes has suffered because of the Zika scare in Brazil. The security situation in Santa Marta has deteriorated, with the return of exchanges of gunfire between drug traffickers and the 
UPP officers in March of 2015. The construction of the resettlement buildings has been halted for the fiscal crisis as well, with no expected restart date forthcoming. Rio's outgoing mayor Eduardo Paes, a major figure in the C40 of global cities, gave a TED talk in 2012 on best practices for global cities called "The Four Commandments for Cities" where he said his mission was to provide a "positive legacy for all of Rio's citizens" by upgrading infrastructure and making Rio into a "smart city". ${ }^{95}$ Paes promoted Rio's urbanization programs for favelas and argued that social integration was his most important goal for favelas. Rio’s former head of security, José Beltrame, said after announcing his resignation in 2016 that the UPP program failed to integrate favelas because the government of Rio didn't follow through on promises to improve living conditions for favela residents. Beltrame also spoke in support of decriminalizing drugs as a means to reduce violence in Rio by economizing police resources.

In Santa Marta where there were improvements to infrastructure like the tram and health center, residents frequently criticized state priorities that were more oriented towards creating a façade of security than they were on improving the primary concerns of residents, like upgrading the sewage system and addressing water and electricity outages. The UPP program expanded the possibilities for urban improvements in Rio's favelas, while the government of Rio prioritized highly visible and costly projects like cable cars, stadiums, and the ecobarrier. Although Rio's built environment was transformed by the government construction projects leading up to the 2016 Olympics, the sustainability of the UPP program and the effort to expand state services to favelas is

\footnotetext{
95 http://www.ted.com/talks/eduardo_paes the 4 commandments_of_cities/transcript?language=en, accessed December 15, 2012.
} 
imperiled by Rio's fiscal crisis in 2016, brought on by an over dependence on petroleum revenues and the massive spending on the World Cup and Olympics. 


\section{References}

Abreu, Maurício de A., ed. 1992. Natureza E Sociedade No Rio de Janeiro. Biblioteca Carioca, v. 21. Rio de Janeiro: Prefeitura da Cidade do Rio de Janeiro, Secretaria Municipal de Cultura, Turismo e Esportes, Departmento Geral de Documentação e Informação Cultural, Divisão de Editoração.

Agrawal, Arun. 2005. Environmentality: Technologies of Government and the Making of Subjects. New Ecologies for the Twenty-First Century. Durham: Duke University Press.

Alvaro Ferreira. 2009. "Favelas No Rio de Janeiro: Nascimento, Expansão, Remoção E, Agora, Exclusão Através de Muros." Biblio 3w: Revista Bibliográfica de Geografia Y Ciencias Sociales 14 (828). http://www.ub.edu/geocrit/b3w-828.htm.

Anderson, Ben. 2010. "Preemption, Precaution, Preparedness: Anticipatory Action and Future Geographies.” Progress in Human Geography 34 (6): 777-98. doi:10.1177/0309132510362600.

Araujo and Miliotti. 2009. "Observatório de Favelas.” Muro Para Quem? September 30. http://www.observatoriodefavelas.org.br Accessed July 13, 2015.

Bakker, Karen. 2013. “Constructing 'public' Water: The World Bank, Urban Water Supply, and the Biopolitics of Development." Environment and Planning D: Society and Space 31 (2): 280-300. doi:10.1068/d5111.

BBC Brasil. 2007. "Imagens de Satélite Revelam Avanço de Favelas No Rio; Veja." http://www.bbc.co.uk/portuguese/reporterbbc/story/2007/09/070928_favelas_cres cimento_cg.shtml. Accessed November 3, 2010.

BBC News. 2004. “Campaigners Decry Rio Slum Wall.” BBC, April 12, sec. Americas. http://news.bbc.co.uk/2/hi/americas/3620847.stm. Accessed October 8, 2010.

Benmergui, Leandro Daniel. 2012. "Housing Development: Housing Policy, Slums, and Squatter Settlements in Rio de Janeiro, Brazil and Buenos Aires, Argentina, 19481973." PhD Dissertation, College Park, Maryland: University of Maryland. 
Biermann, Christine, and Becky Mansfield. 2014. "Biodiversity, Purity, and Death: Conservation Biology as Biopolitics." Environment and Planning D: Society and Space 32 (2): 257-73. doi:10.1068/d13047p.

Brand, Peter. 2007. "Green Subjection: The Politics of Neoliberal Urban Environmental Management." International Journal of Urban and Regional Research 31 (3): 616-32. doi:10.1111/j.1468-2427.2007.00748.x.

Braun, Bruce. 2000. "Producing Vertical Territory: Geology and Governmentality in Late Victorian Canada." Cultural Geographies 7 (1): 7-46. doi:10.1177/096746080000700102. . 2005. "Environmental Issues: Writing a More-than-Human Urban Geography." Progress in Human Geography 29 (5): 635-50. doi:10.1191/0309132505ph574pr. . 2014. "A New Urban Dispositif? Governing Life in an Age of Climate Change." Environment and Planning D: Society and Space 32 (1): 49-64. doi:10.1068/d4313.

Brown, K. 2014. "Global Environmental Change I: A Social Turn for Resilience?" Progress in Human Geography 38 (1): 107-17. doi:10.1177/0309132513498837.

Brum, Mario. 2012. Cidade Alta: história, memórias e estigma de favela num conjunto habitacional do Rio de Janeiro. Rio de Janeiro, RJ: Ponteio. . 2013. "Favelas E Remocionismo Ontem E Hoje: Da Ditadura de 1964 Aos Grandes Eventos." O Social Em Questao 16 (29): 179-208.

Burgos, Marcelo Baumann. 1998. "Dos parques proletários ao Favela-Bairro as políticas públicas nas favelas do Rio de Janeiro." In Um século de favela, edited by Alba Zaluar and Marcos Alvito. Rio de Janeiro, Brasil: Fundação Getulio Vargas Editora.

Cabral, Sergio. 2010. "DECRETO N. ${ }^{\circ} 42.406$ Morar Seguro.” Minesterio Da Fazenda. April 13. http://www.fazenda.rj.gov.br

Caldeira, Teresa, and James Holston. 2005. "State and Urban Space in Brazil." In Global Assemblages: Technology, Politics, and Ethics as Anthropological Problems, edited by Stephen J. Collier and Aihwa Ong. Malden, MA: Blackwell Pub. 
Camargo, Jean Carlos Gomes. 2012. “Ecolimites Ou Sócio-Limites?” January 25. http://web.observatoriodasmetropoles.net. Accessed June 29, 2013.

Cardoso, Adauto Lúcio, and Rosane Lopes de Araujo. 2007. "Habitação Social Na Região Metropolitana Do Rio de Janeiro.” In Habitação Social Nas Metrópoles Brasileiras: Uma Avaliação Das Políticas Habitacionais Em Belém, Belo Horizonte, Porto Alegre, Recife, Rio de Janeiro E São Paulo No Final Do Século $X X$, edited by Will Robson Coelho. Coleção Habitare. Porto Alegre: Habitare.

Carro, Rodrigo. 2004. "Reação Leva Conde a Desistir de Muro Em Torno de Favelas." UOL News. April 13. http://noticias.uol.com.br/economia/ultnot/valor/2004/04/13/ult1913u5858.jhtm. Accessed February 8, 2010.

Carse, Ashley. 2014. Beyond the Big Ditch: Politics, Ecology, and Infrastructure at the Panama Canal. Infrastructures Series. Cambridge, Massachusetts: The MIT Press.

Cavalcanti, Mariana. 2007. "Redefining (il)legal Boundaries." In Cities of the South: Citizenship and Exclusion in the Twenty-First Century/, edited by Barbara Drieskens, Franck Mermier, and Heiko Wimmen. London : Saqi,.

Chade, Jamil. 2009. "ONU Critica Construção de Muro Em Favelas Do Rio - Brasil Estadao.com.br.” Estadão. May 6. http://www.estadao.com.br Accessed February 8,2010

Coelho, Maria Cláudia. 2008. "Rio de Janeiro, Sexta-Feira Santa de 2004, Parte 2: as elites cariocas e os conflitos na Rocinha." Teoria e Cultura 3 (1 e 2).

Collier, Stephen J. 2009. "Topologies of Power Foucault's Analysis of Political Government beyond 'Governmentality." Theory, Culture \& Society 26 (6): 78108. doi:10.1177/0263276409347694.

Collier, Stephen J., and Andrew Lakoff. 2015. "Vital Systems Security: Reflexive Biopolitics and the Government of Emergency." Theory, Culture \& Society 32 (2): 19-51. doi:10.1177/0263276413510050. 
Compans, Rose. 2007. "A cidade contra a favela: a nova ameaça ambiental.” Revista Brasileira de Estudos Urbanos e Regionais 9 (1): 83-99. doi:10.13061/rbeur.v9i1.172.

Compans, Rose, and Sérgio Mares Viñas. 2005. "As Especificidades Dos Conflitos Envolvendo Ocupações Irregulares Em áreas Consideradas Impróprias à Urbanização." Revista Rio de Janeiro 16-17 (May-December).

Cunha, Neiva Vieira da, and Marco Antonio da Silva Mello. 2011. "Novos Conflitos Na Cidade: A UPP E O Processo de Urbanização Na Favela." Dilemas (Rio de Janeiro) 4 (3): 371-401.

Daflon, Rogério, and Tulio Brandão. 2009. “O Morro Não é Só Dos Pobres.” O Globo, March 22, Rio edition. Accessed February 8, 2010.

Darier, Éric, ed. 1999. Discourses of the Environment. Oxford ; Malden, Mass: Blackwell.

Davis, Mike. 2006. Planet of Slums. London; New York: Verso.

DeLyser, Dydia, Steve Herbert, Stuart Aitken, Mike Crang, and Linda McDowell, eds. 2010. "Ethnography and Participant Observation." In The SAGE Handbook of Qualitative Geography. Los Angeles; London: SAGE.

Demeritt, David. 2001. "Scientific Forest Conservation and the Statistical Picturing of Nature's Limits in the Progressive-Era United States." Environment and Planning D: Society and Space 19 (4): 431-59. doi:10.1068/d294.

Elden, Stuart. 2007a. "Governmentality, Calculation, Territory." Environment and Planning D: Society and Space 25 (3): 562-80. doi:10.1068/d428t. . 2007b. "Rethinking Governmentality." Political Geography 26 (1): 29-33. doi:10.1016/j.polgeo.2006.08.001.

Emerson, Robert M., Rachel I. Fretz, and Linda L. Shaw. 2011. Writing Ethnographic Fieldnotes. 2nd ed. Chicago Guides to Writing, Editing, and Publishing. Chicago: The University of Chicago Press.

EMOP. 2008. "Governador Inaugura Plano Inclinado No Dona Marta." Government. Estado de Rio de Janeiro. http://www.emop.rj.gov.br 
ERJ. 2012. "Comunidade Dona Marta, Em Botafogo, Recebe Novas Obras de Reurbanização.” January 17. http://www.rj.gov.br

Escobar, Arturo. 1996. "Constructing Nature: Elements for a Poststructural Political Ecology." In Liberation Ecologies: Environment, Development, Social Movements, edited by Richard Peet, Michael Watts, and Michael Watts. London; New York: Routledge. 1998. "Whose Knowledge, Whose Nature? Biodiversity, Conservation, and the Political Ecology of Social Movements." Journal of Political Ecology 5 (1): 5382.

Evans, Brad, and Julian Reid. 2014. Resilient Life: The Art of Living Dangerously. Cambridge, UK ; Malden, MA: Polity Press.

Evans, Peter B., ed. 2002. Livable Cities?: Urban Struggles for Livelihood and Sustainability. Berkeley: University of California Press.

Faulhaber, Lucas, and Lena Azevedo. 2016. SMH 2016: Removals in the Olympic City. Kindle. Mórula Editorial.

Fernandes, Edesio. 1995. Law and Urban Change in Brazil. Aldershot, Hants, England; Avebury,.

Fiori, Jorge, and Zeca Brandão. 2010. "Spatial Strategies and Urban Social Policy: Urbanism and Poverty Reduction in the Favelas of Rio de Janeiro." In Rethinking the Informal City: Critical Perspectives from Latin America, edited by Lea K. Allen, Peter Kellett, and Felipe Hernández, 181-205. Remapping Cultural History, v. 11. New York: Berghahn Books.

Fiori, Jorge, Liz Riley, and Ronaldo Ramirez. 2000. "Urban Poverty Alleviation Through Environmental Upgrading in Rio de Janeiro: Favela-Bairro.” R7343. Development Planning Unit. London: Development Planning Unit: University College London.

Fischer, Brodwyn M. 2008. A Poverty of Rights: Citizenship and Inequality in TwentiethCentury Rio de Janeiro. Stanford, Calif: Stanford University Press. 
Fletcher, Robert. 2010. "Neoliberal Environmentality: Towards a Poststructuralist Political Ecology of the Conservation Debate." Conservation and Society 8 (3): 171. doi:10.4103/0972-4923.73806.

Folha de Sao Paulo. 2009. "Folha de S.Paulo - Muros Que Limitam Favelas Dividem Opiniões No Rio.” News Media. Folha de Sao Paulo. April 13. http://www1.folha.uol.com.br/fsp/cotidian/ff1304200901.htm. Accessed February $9,2010$.

Forsyth, Tim. 2003. Critical Political Ecology: The Politics of Environmental Science. London; New York: Routledge.

Foucault, M. 2008. The Birth of Biopolitics: Lectures at the Collège de France, 19781979. Palgrave Macmillan UK.

Foucault, Michel, Mauro Bertani, Alessandro Fontana, François Ewald, David Macey, and David Macey. 2003. Society Must Be Defended: Lectures at the Collège de France, 1975-76. 1st ed. New York: Picador.

Foucault, Michel, and James D. Faubion. 2001. Power. Essential Works of Foucault, 1954-1984, v. 3. London: Allen Lane.

Foucault, Michel, Michel Senellart, François Ewald, and Alessandro Fontana. 2007. Security, Territory, Population: Lectures at the Collège de France, 1977-78. Michel Foucault: Lectures at the Collège de France. Basingstoke; New York: Palgrave Macmillan : République Française.

Freire, Aluizio. 2007. "Cabral Defende Aborto Contra Violência No Rio de Janeiro." G1, October 24, Online edition, sec. Política. http://g1.globo.com Accessed April 16, 2012.

Freitas, S. R., C. L. Neves, and P. Chernicharo. 2006. “Tijuca National Park: Two Pioneering Restorationist Initiatives in Atlantic Forest in Southeastern Brazil." Brazilian Journal of Biology 66 (4): 975-82. doi:10.1590/S151969842006000600004.

Fuks, Mario. 1998. "Environment-Related Litigation in Rio de Janeiro: Shaping Frames for a New Social Problem." International Journal of Urban and Regional Research 22 (3): 394-407. doi:10.1111/1468-2427.00148. 
Gandy, Matthew. 2006. "Zones of Indistinction: Bio-Political Contestations in the Urban Arena." Cultural Geographies 13 (4): 497-516.

doi:10.1191/1474474006cgj372oa.

Gardner, James A. 1972. "Urbanization in Brazil. An International Urbanization Survey Report to the Ford Foundation." http://eric.ed.gov/?id=ED079451.

Garmany, Jeff. 2011. "Drugs, Violence, Fear, and Death: The Necro- and NarcoGeographies of Contemporary Urban Space." Urban Geography 32 (8): 1148-66. doi:10.2747/0272-3638.32.8.1148.

- 2014. "Space for the State? Police, Violence, and Urban Poverty in Brazil." Annals of the Association of American Geographers 104 (6): 1239-55. doi:10.1080/00045608.2014.944456.

Gay, Robert. 1994. Popular Organization and Democracy in Rio de Janeiro: A Tale of Two Favelas. Philadelphia: Temple University Press.

GEG. 1969. Rio, operação favela. Edited by Guanabara (Brazil : State). [Rio de Janeiro]: O Governo.

Geo-Rio. 2005. "Plano Municipal de Redução de Risco: Relatório Cartografia de Risco Quantitativo a Escorregamentos Em Setores de Assentamento Precários Na Cidade Do Rio de Janeiro." Prefecture of Rio de Janeiro. www.rio.rj.gov.br/obras. . 2006. "Experiência Do Município Do Rio de Janeiro Na Gestão de Risco de Deslizamentos de Encostas Através Da Fundação GEO RIO.” Fundação Instituto Geotécnica do Município do Rio de Janeiro Geo-Rio. http://www.cidades.gov.br

Ghertner, Asher. 2011. 'Green Evictions: Environmental Discourses of a 'Slum-Free' Delhi.” In Global Political Ecology, edited by Richard Peet, Paul Robbins, and Michael Watts. Abingdon, Oxon; New York, NY: Routledge. . 2014. "India's Urban Revolution: Geographies of Displacement beyond Gentrification." Environment and Planning A 46 (7): 1554-71. doi:10.1068/a46288.

Global Justice. 2009. “Os Muros Nas Favelas E O Processo de Criminalização - Justiça Global.” Global Justice Brazil. May 23. http://global.org.br/programas/os-murosnas-favelas-e-os-processos-de-criminalizacao/. Accessed October 21, 2010. 
Goldman, Mara, Paul Nadasdy, and Matt Turner, eds. 2011. Knowing Nature: Conversations at the Intersection of Political Ecology and Science Studies. Chicago ; London: University of Chicago Press.

Goldman, Michael. 2001. "Constructing an Environmental State: Eco-Governmentality and Other Transnational Practices of a 'Green' World Bank." Social Problems 48 (4): 499-523. doi:10.1525/sp.2001.48.4.499.

- 2005. Imperial Nature: The World Bank and Struggles for Justice in the Age of Globalization. Yale Agrarian Studies. New Haven, Conn. ; London: Yale University Press.

Goldstein, Donna M. 2003. Laughter out of Place: Race, Class, Violence, and Sexuality in a Rio Shantytown. California Series in Public Anthropology 9. Berkeley: University of California Press.

Gonçalves, Rafael Soares. 2013. Favelas do Rio de Janeiro: história e direito. Rio de Janeiro, RJ: Pallas : Editora PUC-Rio.

Grove, Kevin. 2013a. "From Emergency Management to Managing Emergence: A Genealogy of Disaster Management in Jamaica." Annals of the Association of American Geographers 103 (3): 570-88. doi:10.1080/00045608.2012.740357. . 2013b. "From Emergency Management to Managing Emergence: A Genealogy of Disaster Management in Jamaica." Annals of the Association of American Geographers 103 (3): 570-88. doi:10.1080/00045608.2012.740357.

_ 2013c. "Hidden Transcripts of Resilience: Power and Politics in Jamaican Disaster Management.” Resilience 1 (3): 193-209. doi:10.1080/21693293.2013.825463. .2014a. "Biopolitics and Adaptation: Governing Socio-Ecological Contingency Through Climate Change and Disaster Studies: Biopolitics and Adaptation." Geography Compass 8 (3): 198-210. doi:10.1111/gec3.12118.

_ 2014b. "Adaptation Machines and the Parasitic Politics of Life in Jamaican Disaster Resilience: Adaptation Machines.” Antipode 46 (3): 611-28. doi:10.1111/anti.12066.

Grupo Eco. 2011. Reunião/Urbanização - Parte 1. TV Favela. Santa Marta. https://www.youtube.com/watch?v=F1evcVrD0Do.

Harvey, David. 1996. Justice, Nature, and the Geography of Difference. Cambridge, Mass: Blackwell Publishers. 
Hay, Iain, ed. 2010. Qualitative Research Methods in Human Geography. 3rd ed. Oxford ; New York: Oxford University Press.

Heynemann, Cláudia B. 1995. Floresta Da Tijuca : Natureza E Civilização No Rio de Janeiro, Século XIX /. Rio de Janeiro, RJ : Prefeitura da Cidade do Rio de Janeiro, Secretaria Municipal de Cultura, Departamento Geral de Documentação e Informação Cultural.

Heynen, Nik. 2013. "Urban Political Ecology I: The Urban Century." Progress in Human Geography, August, 0309132513500443. doi:10.1177/0309132513500443.

Huchzermeyer, Marie, and Aly Karam. 2006. Informal Settlements: A Perpetual Challenge? Juta and Company Ltd.

IBDF. 1981. "Plano de Manejo: Parque Nacional Da Tijuca." Instituto Brasileiro de Desenvolvimento Florestal. Brasília. IBGE Rio de Janeiro.

ICMCBio. 2008. "Parque Nacional Da Tijuca Plano de Manejo." Plano de Manejo Volume I. Brasília: Ministerio do Meio Ambiente, Brasil. http://www.icmbio.gov.br

IETS. 2010. "Primeira Análise Da Pesquisa Socioeconômica E Do Perfil de Gestão de Risco Das Populações Dos Morros Santa Marta, Babilônia E Chapéu Mangueira." Market Research and Demographics. Rio de Janeiro, RJ, Brazil: Instituto de Estudos do Trabalho e Sociedade.

INPE. 2008. "INPE / Notícias - INPE E SOS Mata Atlântica Divulgam Dados de Desmatamento Nas Regiões Metropolitanas de São Paulo, Rio de Janeiro E Vitória." http://www.inpe.br/noticias/noticia.php?Cod_Noticia=1701.

IPP. 2005. "Indicadores Ambientais Da Cidade Do Rio de Janeiro." Coleções de estatísticas gerais. Rio de Janeiro, RJ, Brazil: Prefecture of Rio de Janeiro. http://portalgeo.rio.rj.gov.br . 2014. "Panarama Dos Territorios: UPP Santa Marta." Municipal Government. Panarama Dos Territorios. Rio de Janeiro, RJ, Brazil: Instituto Municipal de Urbanismo Pereira Passos. 
Janoschka, Michael, and Jorge Sequera. 2016. "Gentrification in Latin America: Addressing the Politics and Geographies of Displacement." Urban Geography, February. http://www.tandfonline.com/doi/abs/10.1080/02723638.2015.1103995.

Jones, Fred O. 1973. "Landslides of Rio de Janeiro and the Serra Das Araras, Brazil." Geological Survey Professional Paper 697. Rio de Janeiro: USAID. United States Department of the Interior.

Keil, Roger. 2005. “Progress Report—Urban Political Ecology.” Urban Geography 26 (7): 640-51. doi:10.2747/0272-3638.26.7.640.

Koonings, Kees, and Dirk Kruijt, eds. 2007. Fractured Cities: Social Exclusion, Urban Violence and Contested Spaces in Latin America. London; New York: New York: Zed Books ; Distributed in the USA exclusively by Palgrave Macmillan. ., eds. 2009. Megacities: The Politics of Urban Exclusion and Violence in the Global South. London; New York: Zed Books.

Lave, Rebecca. 2012. "Bridging Political Ecology and STS: A Field Analysis of the Rosgen Wars." Annals of the Association of American Geographers, February. http://www.tandfonline.com/doi/full/10.1080/00045608.2011.641884. - 2015. "The Future of Environmental Expertise." Annals of the Association of American Geographers, February. http://www.tandfonline.com/doi/full/10.1080/00045608.2014.988099.

Legg, Stephen. 2005. "Foucault's Population Geographies: Classifications, Biopolitics and Governmental Spaces." Population, Space and Place 11 (3): 137-56. doi:10.1002/psp.357.

_ 2006. "Governmentality, Congestion and Calculation in Colonial Delhi." Social \& Cultural Geography 7 (5): 709-29. doi:10.1080/13698240600974721.

- 2008. Spaces of Colonialism: Delhi's Urban Governmentalities. John Wiley \& Sons.

Lemos, Tomás Mariani. 2011. "Expansão Das áreas de Favela E de Risco Em Torno Do Parque Da Tijuca, Rio de Janeiro.” Master's Thesis, Rio de Janeiro, RJ, Brazil: PUC-RIO.

Li, Tania Murray. 2007a. The Will to Improve: Governmentality, Development, and the Practice of Politics. Durham: Duke University Press.

— 2007b. "Practices of Assemblage and Community Forest Management." Economy and Society 36 (2): 263-93. doi:10.1080/03085140701254308. 
. 2010. "To Make Live or Let Die? Rural Dispossession and the Protection of Surplus Populations." Antipode 41 (January): 66-93. doi:10.1111/j.14678330.2009.00717.x.

Luke, Timothy W. 1995. "On Environmentality: Geo-Power and Eco-Knowledge in the Discourses of Contemporary Environmentalism.” Cultural Critique, no. 31 (October): 57-81. doi:10.2307/1354445.

MacKinnon, D., and Derickson, K. D. 2013. "From resilience to resourcefulness: A critique of resilience policy and activism." Progress in Human Geography. 37 (2): 253-270. doi: 10.1177/0309132512454775

Magalhães, Sérgio. 2009. “Contra: Muro Ou Trincheira? -.” Folha de S.Paulo, April 13. http://www1.folha.uol.com.br/fsp/cotidian/ff1304200902.htm. Accessed February 8,2010

Martin, L., and A. J. Secor. 2014. "Towards a Post-Mathematical Topology.” Progress in Human Geography 38 (3): 420-38. doi:10.1177/0309132513508209.

McCann, Bryan. 2014. Hard Times in the Marvelous City: From Dictatorship to Democracy in the Favelas of Rio de Janeiro. Durham: Duke University Press.

McNeely, Jeffrey A., International Union for Conservation of Nature and Natural Resources, World Resources Institute, Conservation International, World Wildlife Fund--U.S, World Bank, and International Bank for Reconstruction and Development, eds. 1990. Conserving the World's Biological Diversity. Gland, Switzerland: Washington, D.C: IUCN; WRI : CI : WWF-US : World Bank.

Meade, Teresa A. 1997. “Civilizing” Rio Reform and Resistance in a Brazilian City, 1889-1930. University Park, Pa.: Pennsylvania State University Press.

Mendonça, Alba Valéria. 2008. "Cabral Inaugura Plano Inclinado No Morro Dona Marta.” News media. G1 > Edição Rio de Janeiro - NOTÍCIAS -. May 29. http://g1.globo.com Accessed February 8, 2010. . 2009. "Lula Visita Duas Favelas Cariocas Nesta Terça-Feira." News media. G1 > Brasil - NOTÍCIAS. March 2. http://g1.globo.com Accessed February 8, 2010. 
MMA-SBF Brazil. 2011. “Áreas de Preservação Permanente E Unidades de Conservação \& Áreas de Risco. O Que Uma Coisa Tem a Ver Com a Outra?” Inspection Summary. Brasilia, Distrito Federal, Brasil: Minestério do Meio Ambiente Secretaria de Biodiversidade e Florestas do Brasil.

Moreno, Ícaro Júnior. 2009. “Folha de S.Paulo - A Favor: Os Muros Verdes.” April 13. http://www1.folha.uol.com.br/fsp/cotidian/ff1304200903.htm. Accessed March 4, 2010 .

Munasinghe, Mohan, Braz Menezes, and Martha Preece. 1991. "Case Study: Rio Flood Reconstruction and Prevention Project." 9813. Managing Natural Disasters and the Environment : Selected Materials from the Colloquium on the Environment and Natural Disaster Management. World Bank.

Netto, Ana Luiza Coelho. 2005. “A Interface Florestal-Urbana E Os Desastres Naturais Relacionados à água No Maciço Da Tijuca: Desafios Ao Planejamento Urbano Numa Perspectiva Sócio-Ambiental.” Revista Do Departamento de Geografia 16 (0): 46-60. doi:10.7154/RDG.2005.0016.0005.

Neumann, Roderick. 1998. Imposing Wilderness: Struggles Over Livelihood and Nature Preservation in Africa. University of California Press. 2001. "Disciplining Peasants in Tanzania: From State Violence to SelfSurveillance in Wildlife Conservation." In Violent Environments, edited by Nancy Lee Peluso and Michael Watts. Cornell University Press.

- 2005. Making Political Ecology. Human Geography in the Making. London : New York: Hodder Arnold; Distributed in the United States of America by Oxford University Press Inc.

Nilton de Souza, José. 2009. "A exclusão pela urbanização favela: Governo e conflito na cidade do Rio de Janeiro.” GEOgraphia 5 (10). http://www.uff.br/geographia/ojs/index.php/geographia/article/view/127.

Nogueira and Zahar. 2009. "Rio Fará Muro Em 11 Favelas de área Nobre.” Folha de S.Paulo. April 2. http://www1.folha.uol.com.br/fsp/cotidian/ff0204200901.htm.

O Globo. 2011. “G1 - Mapeamento Do Rio Aponta 18 Mil Imóveis Em áreas de Alto Risco - Notícias Em Rio de Janeiro.” O Globo G1. January 6. http://g1.globo.com Accessed April 23, 2012. 
Olinger, Marianna. 2015. "Entre Mercado E Clientela, a Manutenção Do Poder: Urbanização de Favelas No Rio de Janeiro 1993-2013.” PhD Dissertation, Rio de Janeiro, RJ, Brasil: Universidade Federal do Rio de Janeiro/IPPUR.

Oliveira, Lúcia Lippi, ed. 2002. Cidade: História E Desafios. Rio de Janeiro: Editora FGV : CNPq.

Outtes, Joel. 2003. "Disciplining Society through the City: The Genesis of City Planning in Brazil and Argentina (1894-1945)." Bulletin of Latin American Research 22 (2): 137-64. doi:10.1111/1470-9856.00069.

Pain, Rachel. 2004. "Social Geography: Participatory Research." Progress in Human Geography 28 (5): 652-63. doi:10.1191/0309132504ph511pr.

Pandolfi, Dulce Chaves, and Mário Grynszpan. 2003. A favela fala: depoimentos ao $C P D O C$. Centro de Pesquisa e Documentação de História Contemporânea do Brasil (Fundação Getúlio Vargas). Rio de Janeiro, RJ, Brasil: FGV Editora.

Peet, Richard, Paul Robbins, and Michael Watts, eds. 2011. Global Political Ecology. Abingdon, Oxon; New York, NY: Routledge.

Peet, Richard, and Michael Watts, eds. 1996. Liberation Ecologies: Environment, Development, Social Movements. London; New York: Routledge.

Peixoto, Sônia, Marta Irving, Ana Paula Leite Prates, and Iara Vasco Ferreira. 2007. "Parque Urbano da Paz: A Construção de um Novo Conceito no Parque Nacional da Tijuca." RDE - Revista de Desenvolvimento Econômico 7 (11). http://www.revistas.unifacs.br/index.php/rde/article/view/93.

Pelling, M., and K. Dill. 2010. "Disaster Politics: Tipping Points for Change in the Adaptation of Sociopolitical Regimes.” Progress in Human Geography 34 (1): 21-37. doi:10.1177/0309132509105004.

Penglase, Ben. 2014. Living with Insecurity in a Brazilian Favela: Urban Violence and Daily Life. New Brunswick, New Jersey: Rutgers University Press.

Perlman, Janice E. 1976. The Myth of Marginality: Urban Poverty and Politics in Rio de Janeiro. Berkeley, Calif: University of California Press. 2010. Favela: Four Decades of Living on the Edge in Rio de Janeiro. Oxford; New York: Oxford University Press. 
Petersen, Maria Lúcia. 2004.

http://www.vitruvius.com.br/revistas/read/entrevista/05.019/3327?page=1.

Accessed July 19, 2012.

Phillips, Tom. 2009. "Rio Slum Barrier Plans Spark Outcry." The Guardian, January 6, sec. World news. http://www.guardian.co.uk/world/2009/jan/06/brazil-rio-slumbarrier. Accessed February 8, 2010.

Regalado, Antonio. 2009. "Walls Around Rio's Slums Protect Trees But Don’t Inspire Much Hugging." WSJ. June 15. http://www.wsj.com/articles/SB124501964322813585. Accessed February 8, 2010.

RioOnWatch. 2016. "What Does the Brazilian Constitution Say About Housing Rights?" RioOnWatch. May 18. http://www.rioonwatch.org/?p=25334.

Roy, Ananya. 2005. "Urban Informality: Toward an Epistemology of Planning." Journal of the American Planning Association 71 (2): 147-58. doi:10.1080/01944360508976689.

Roy, Ananya, and Nezar AlSayyad, eds. 2004. Urban Informality: Transnational Perspectives from the Middle East, Latin America, and South Asia. Transnational Perspectives on Space and Place. Lanham, Md. : Berkeley, Calif: Lexington Books ; Center for Middle Eastern Studies, University of California at Berkeley.

Rutherford, Paul. 1999. “The Entry of Life Into History.” In Discourses of the Environment, edited by Éric Darier. Oxford; Malden, Mass: Blackwell.

Rutherford, Paul, and Stephanie Rutherford. 2013. "The Confusions and Exuberances of Biopolitics." Geography Compass 7 (6): 412-22. doi:10.1111/gec3.12046.

Rutherford, Stephanie. 2007. "Green Governmentality: Insights and Opportunities in the Study of Nature's Rule." Progress in Human Geography 31 (3): 291-307. doi: $10.1177 / 0309132507077080$.

Rutherford, Stephanie, and Paul Rutherford. 2013. "Geography and Biopolitics." Geography Compass 7 (6): 423-34. doi:10.1111/gec3.12047. 
Salles, Fernanda. 2011. "Fernanda Salles - Projeto de Urbanização Da Comunidade Santa Marta." Architecture/Urban Mobility presented at the Workshop Inserção do Transporte Sustentável no Morar Carioca, Rio de Janeiro, October 10.

Scheper-Hughes, Nancy. 1992. Death without Weeping: The Violence of Everyday Life in Brazil. Berkeley: University of California Press.

Schmidt, Selma. 2007. "Rio Ganha 4.5 Morros Santa Marta de Areas Faveladas Em Cinco Anos." O Globo, September 16, Matutino edition, sec. Rio.

Schmidt, Selma, and Paulo Marquero. 2004. "Barracos Em Expansão.” O Globo, May 16, Weekly edition, sec. Rio.

Silva, Itamar. 2003. A favela fala: depoimentos ao CPDOC. Edited by Dulce Chaves Pandolfi and Mário Grynszpan. Centro de Pesquisa e Documentação de História Contemporânea do Brasil (Fundação Getúlio Vargas). Rio de Janeiro, RJ, Brasil: FGV Editora. .2011. "Santa Marta." In Santa Marta: O Morro E Sua Gente, edited by Roberto Boavista. Rio de Janeiro, RJ, Brazil: Instituto de Estudos do Trabalho e Sociedade.

SMU-RJ. 1992. "Plano Diretor Decenal Da Cidade Do Rio de Janeiro.” Edited by Secretaria Municipal de Urbanismo, Rio de Janeiro. Prefeitura da Cidade do Rio de Janeiro.

Soares, Ronaldo. 2009. “A Favela No Limite.” Revista Veja. April 22.

Srinivasan, Krithika. 2014. "Caring for the Collective: Biopower and Agential Subjectification in Wildlife Conservation." Environment and Planning D: Society and Space 32 (3): 501-17. doi:10.1068/d13101p.

Swyngedouw, Erik, and Nikolas C Heynen. 2003. "Urban Political Ecology, Justice and the Politics of Scale." Antipode 35 (5): 898-918. doi:10.1111/j.14678330.2003.00364.x.

Teresa Caldeira. 2000. City of Walls: Crime, Segregation, and Citizenship in São Paulo. Berkeley: University of California Press. 
UNDRO. 1984. Disaster Prevention and Mitigation: A Compendium of Current Knowledge. Vol. 11, Vol. 11,. New York: United Nations.

UNISDR. 2013. "Disaster Risk Reduction in the United Nations 2013: Roles, Mandates and Results of Work of Key United Nations Entities." Disaster Risk Reduction. United Nations Office for Disaster Risk Reduction. https://www.unisdr.org/we/inform/publications/32918.

Valladares, Licia do Prado. 1978. Passa-Se Uma Casa : Análise Do Programa de Remoção de Favelas Do Rio de Janeiro. Rio de Janeiro: Zahar Editores. 2005. A Invenção Da Favela: Do Mito de Origem a Favela.com. 1a ed. Rio de Janeiro: Editora FGV. . 2008. "Social Science Representations of Favelas in Rio de Janeiro: A Historical Perspective." Lanic Etext Collection University of Texas Austin. http://lanic.utexas.edu/project/etext/liilas/vrp/valladares.pdf.

Valla, Victor. 1986. Educação E Favela : Políticas Para as Favelas Do Rio de Janeiro, 1940-1985. Petrópolis: Vozes em co-edição com Associação Brasileira de PósGraduação em Saúde Coletiva.

Varley, Ann. 2013. "Postcolonialising Informality?" Environment and Planning D: Society and Space 31 (1): 4-22. doi:10.1068/d14410.

Vaz, Paulo, Mariana Cavalcanti, Luciana Julião de Oliveira, and Carolina Sá-Carvalho. 2007. "Pobreza E Risco: A Imagem Da Favela No Noticiário de Crime.” Revista Fronteiras-Estudos Midiáticos 7 (2).

Velasquez-Manoff, Moises. 2009. "Ire over Proposed 'Eco-Barriers' in Rio de Janeiro." Bright Green- The Christian Science Monitor. September 25. http://www.csmonitor.com/Environment/Bright-Green/2009/0925/ire-overproposed-eco-barriers-in-rio-de-janeiro. Accessed February 8, 2010.

Vial, Adriana, and Fernando Cavallieri. 2009. "O Efeito Da Presença Governamental Sobre a Expansão Das Favelas Do Rio: Os POUSO's E O Programa FavelaBairro.” Municipal Government 20090501. Coleção Estudos Cariocas. Rio de Janeiro, RJ, Brazil: Instituto Municipal de Urbanismo Pereira Passos. http://portalgeo.rio.rj.gov.br

Watts, Michael, and Richard Peet, eds. 2004. Liberation Ecologies: Environment, Development, Social Movements. 2nd ed. London; New York: Routledge. 
West, Paige. 2006. Conservation Is Our Government Now: The Politics of Ecology in Papua New Guinea. New Ecologies for the Twenty-First Century. Durham: Duke University Press.

West, Paige, James Igoe, and Dan Brockington. 2006. "Parks and Peoples: The Social Impact of Protected Areas." Annual Review of Anthropology 35 (1): 251-77. doi:10.1146/annurev.anthro.35.081705.123308.

Wisner, Ben, Piers Blaikie, Terry Cannon, and Ian Davis, eds. 2004. At Risk: Natural Hazards, People's Vulnerability and Disasters. 2nd ed. Routledge ; New York: Routledge.

Wolford, Wendy. 2010. This Land Is Ours Now: Social Mobilization and the Meanings of Land in Brazil. New Ecologies for the Twenty-First Century. Durham [NC]: Duke University Press.

World Bank. 1988. "Brazil - Rio Flood Reconstruction and Prevention Project.” P4833. The World Bank.

http://documents.worldbank.org/curated/en/1988/06/737569/brazil-rio-floodreconstruction-prevention-project. . 1996. "Brazil - Rio Reconstruction and Prevention Project." 16183. The World Bank. http://documents.worldbank.org/curated/en/1996/12/727176/brazil-rioreconstruction-prevention-project.

. 2011. "World Bank Supports Brazil's Disaster Prevention Efforts." Worldbank.org. January 18. http://www.worldbank.org/en/news/pressrelease/2011/01/18/world-bank-supports-brazils-disaster-prevention-efforts.

—. 2012a. "Improving the Assessment of Disaster Risks to Strengthen Financial Resilience." Issuu. https://issuu.com/world.bank.publications/docs/gfdrr_g20_high. . 2012b. "Urban Risk Assessments : Understanding Disaster and Climate Risk in Cities." 70982. The World Bank. http://documents.worldbank.org/curated/en/2012/06/16499064/urban-riskassessments-understanding-disaster-climate-risk-cities. . 2012c. "Bringing the State Back into the Favelas of Rio de Janeiro : Understanding Changes in Community Life after the UPP Pacification Process," October. https://openknowledge.worldbank.org/handle/10986/13230.

Zahar, Andre. 2009. "Rio Descartou Muro Mais Baixo Para Favelas." Folha de SPCotidiano. April 4. http://www1.folha.uol.com.br/fsp/cotidian/ff0404200929.htm. Accesed February 8, 2010. 
Zeiderman, Austin. 2012. "On Shaky Ground: The Making of Risk in Bogotá." Environment and Planning A 44 (7): 1570-88. doi:10.1068/a44283. . 2013. "Living Dangerously: Biopolitics and Urban Citizenship in Bogotá, Colombia." American Ethnologist 40 (1): 71-87. doi:10.1111/amet.12006. 
Appendix

Letter from Itamar Silva to President Luiz Inácio Lula da Silva. February 3, 2009.

Against the Removal of the Residents from the "Peak of the Hill".

The residents of this part of the favela always suffer the perverse effects of living on the highest part of of the Hill: up there, everything is more difficult: access to water, public lighting and, for a long time, they suffered more intensely the effects called [drug] 'wars' or even police activity in that place. However, this is the place with most beautiful view of the city: from there the view reaches to Cristo Redentor [Christ Redeemer], Pão de Açúcar [Sugar Loaf], the Rodrigo de Freitas lagoon, Copacabana, Botafogo cove and much more. Today, you arrive at that place by the Plano Inclinado [Funicular Tram], installed in the urbanization process of the favela. Up to one hundred tourists come there weekly to enjoy this marvel. So, with the argument that it [the Peak] is a risk area, the government wants to remove people from their houses and 'stack them' in 37 or 40 meter square apartments. Our argument is that it is possible, technically, to do the necessary mitigation works; keep the existing and already upgraded homes; reconstruct those houses in a precarious state, and so preserving an important part of the history of the favela Santa Marta. And this permits those residents that suffered most during the absence of the State, to be able to now benefit from the improvements that come to the Favela. A second point connected with the first: Since, for the first time in Rio de Janeiro, there is a good alignment between the federal government, state, and city governments, Santa Marta has been cited as a model of intervention articulated with the three spheres of the government. We would like for a space of participation to be created, with representatives of the three spheres of government, in order to discuss the continuity of the urbanization process of the Santa Marta favela. We want a valued participation where residents are heard and taken in consideration. 
VITA

\section{CHARLES L. HECK}

\section{Education}

2011

M.A. in Global and Sociocultural Studies

Graduate Certificate in Latin America and Caribbean Studies

Florida International University at Miami, Florida

2010

Fellow in Foreign Language and Areas Studies for Brazilian Portuguese

Latin American and Caribbean Center

Florida International University at Miami, Florida

2008 Foreign Language and Areas Studies for Brazilian Portuguese

Advanced level in language, culture and politics courses

U.S. Department of Education at Rio de Janeiro, RJ, Brazil

2004 Study abroad in intensive Portuguese. Advanced level.

Universidade de Coimbra, Portugal

2004 B.A. in Political Science

University of Minnesota at Minneapolis, MN

\section{$\underline{\text { Conference Presentations }}$}

2016 Paper session: The Biopolitics of Precarity: Risk Mapping and Resilient Life in Rio de Janeiro, American Association of Geography (AAG) annual meeting, San Francisco, CA (April)

2015 Paper session: The Biopolitics of Informal Displacement and the Production of the Environment in Rio de Janeiro, American Association of Geography (AAG) annual meeting, Chicago, IL (April)

2014 Invited presentation: The 2010 Brazilian Census and Favelas: Lots of Data, Lots of Discrepancies. Geographic Information Science Center, FIU

2014 Paper session: Precarious Politics in Rio de Janeiro: Green Urbanism, Favela Politics and Displacement, American Association of Geography (AAG) annual meeting, Tampa, FL (April).

2014 Paper Session: The Green Governmentality of Urban Informality in South America, International Studies Association. (ISA) annual meeting, Toronto, ON, Canada, (March). 
2013 Paper session: Precarious Governance: Ecolimits, Displacement, and Favela Politics; AAG annual meeting, Los Angeles, CA, (April).

2012 Paper session: Precarious Governance: Dispossession and Resistance in Rio's "Pacified" Favelas, Critical Geography conference, UNC, Chapel Hill, (Nov)

2011 Paper session: Environmental Conditionality, Sovereignty, and the Making of Brazilian Development, ISA annual meeting, Montreal, QC, Canada (February) 